UNIVERSIDADE DE BRASÍLIA

FACULDADE DE ADMINISTRAÇÃO, CONTABILIDADE, ECONOMIA,

CIÊNCIA DA INFORMAÇÃO E DOCUMENTAÇÃO-FACE

ARIOSTO NOGUEIRA LUSTOSA

ELDER AYRES CARMONA

\title{
VIABILIDADE DA APLICAÇÃO DO BALANCED SCORECARD EM UMA UNIVERSIDADE PÚBLICA: ANÁLISE DE UMA UNIDADE DESCENTRALIZADA DA UNIVERSIDADE DE BRASÍLIA (UnB)
}




\section{Viabilidade da aplicação do Balanced Scorecard em uma universidade pública: Análise de uma unidade descentralizada da Universidade de Brasília (UnB)}

Monografia apresentada ao Programa de PósGraduação em Administração da Faculdade de Administração, Contabilidade, Economia, Ciência da Informação e Documentação (FACE) da Universidade de Brasília, como requisito parcial a obtenção do grau de Especialista em Desenvolvimento Gerencial.

Aprovação em 15 de junho de 2007.

BANCA EXAMINADORA

Prof. Doutor Gileno F. Marcelino Orientador
Prof. Doutora Catarina Cecília Odelius Convidada 


\section{RESUMO}

O planejamento do ensino superior no Brasil (especialmente no ensino de graduação) tem sido feita com base na experiência adquirida em estudos, projeções de cenários e planejamentos estratégicos. Estes instrumentos têm se mostrado eficientes e eficazes, em que pese o elevado custo. Na década de 90, Kaplan e Norton descreveram - Balanced Scorecard (BSC) como "um conjunto de indicadores que proporciona aos gerentes uma visão rápida e abrangente, de toda a empresa". Estes indicadores são capazes de identificar e quantificar ações do passado e presente, bem como complementar, com indicadores operacionais, qual a satisfação dos clientes, identificar a razoabilidade dos processos internos e a capacidade da organização aprender e melhorar. Estes indicadores, ou medidores de desempenho buscam sintetizar as condições objetivas do mundo real em que a operação efetivamente acontece, traduzindo em números a situação do ambiente, do negócio, da interação entre eles, fazendo a ponte entre a organização e os executivos, de forma a dar conhecimento do desempenho alcançado, em quais condições isto se deu e as manifestações e tendências predominantes. A utilidade desses indicadores de desempenho, portanto, vai além da quantificação numérica dos resultados obtidos e além do conjunto de situações que circunscrevem a operação. Pode-se deduzir que os indicadores do desempenho norteiam as organizações no julgamento da operação e fornecem o referencial para as decisões que definirão o seu futuro. O presente trabalho objetiva, com base na metodologia Balanced Scorecard (BSC), descrever as características desse sistema de gestão estratégica e a sua aplicabilidade a uma universidade pública, tomando como ponto de partida uma Unidade Descentralizada da Universidade de Brasília (UnB)/Centro de Seleção e de Promoção de Eventos (CESPE). Utilizou-se, como método de pesquisa, a pesquisa bibliográfica, levantamento de dados por meio de questionário fechado, entrevistas e visitas a empresas públicas que vivenciaram a implantação do Balanced Scorecard (BSC).

Palavras-chave: gerenciamento, indicadores equilibrados, sistema de mensuração, tendências predominantes. 


\section{AGRADECIMENTOS}

A Deus, por meio de Jesus, pelo dom da vida... A Ele toda honra e toda glória!

Ao Prof. Dr. Gileno Fernandes Marcelino, pela sábia orientação e por ter generosamente colocado o seu muito saber sobre Planejamento Estratégico e Balanced Scorecard a disposição do nosso estudo.

Ao Prof. Dr. Henrique Pontes, pela despretensiosa ajuda, fruto da generosidade e do prazer de disseminar o saber.

À Prof ${ }^{a}$. Dr ${ }^{a}$. Catarina Cecília Odelius, pelo apoio e o carinho somente superados pela sua generosidade e competência.

À Prof ${ }^{\mathrm{a}}$ Dr $^{\mathrm{a}}$ Fátima Bruno, pela orientação segura quanto aos aspectos formais da monografia.

À competentíssima Secretária Vera Oliveira, pelo incentivo sempre carinhoso.

Ao Prof. Dr. Marcos Vinícius, Diretor Acadêmico do CESPE, amigos e colegas de trabalho que apoiaram a idéia da realização do estudo na estrutura do Centro.

À amiga Fabiana Queiroga, pela inestimável contribuição na tarefa de utilização do instrumento SPSS e análise dos dados estatísticos.

Ao meu pai, Adelson, por ter me ensinado que a verdadeira riqueza reside na honradez, no amor a Deus, ao próximo e à natureza...

À minha mulher, Esther, por ter cuidado de mim, de modo integral e com especial amor, durante o tempo que tive ausente do meu cotidiano para me dedicar aos estudos.

Aos meus filhos Bruno e Sólon, por me fazerem acreditar no futuro!

Ao fraterno amigo e parceiro Elder Carmona, pelos ataques de calma nas horas de turbulência.

Ariosto Lustosa
À minha esposa Glacimar, pelo amor, companheirismo, personalidade e resignação.

Aos meus filhos Deivison, Diego (in memorian) e Felipe pelas alegrias de vida que já me deram e pelas muitas que ainda me darão, pelo apoio e ausências que passaram para que eu concluísse esse trabalho.

À minha mãe, pela grandeza, dedicação e amor que sempre nos dedicou.

À minha irmã Fátima, que muito contribuiu para o meu bem-estar atual.

Ao amigo Ariosto Lustosa, que compartilhou momentos de aflição e deu contribuições relevantes a este trabalho. 


\section{Lista de Figuras}

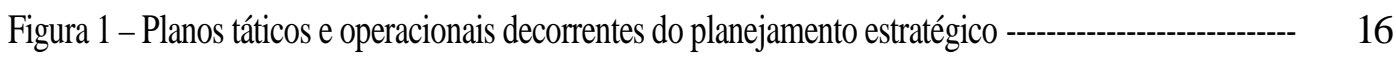

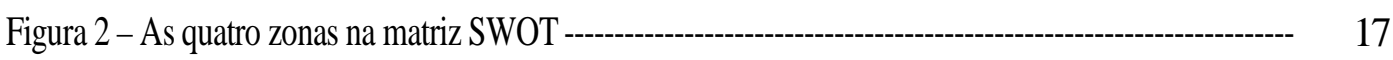

Figura 3 - Concepção de modelo básico de planejamento estratégico------------------------------------- 17

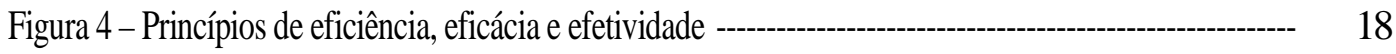

Figura5 - Importância crescente dos ativos intangíveis ----------------------------------- 21

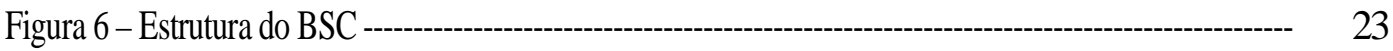

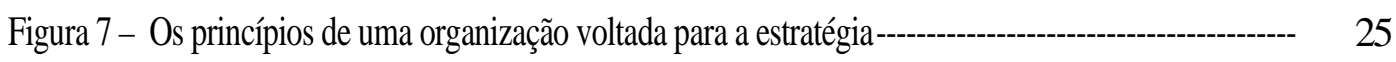

Figura 8 - Organograma do CESPE---o--- 34

Figura 9 - Fases de execução dos projetos no CESPE/UnB -

Figura 10 - Estrutura do BSC aplicado ao serviço público ----------------------------------- $\quad 40$

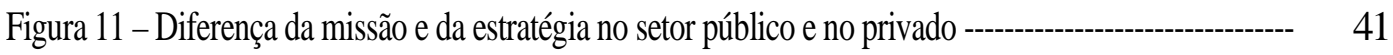

Figura 12 - Diferença da perspectiva financeira do setor público e no setor privado ----------------------- $\quad 42$

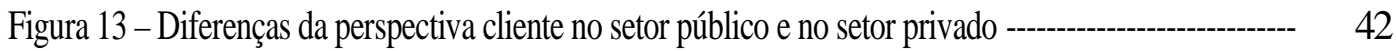

Figura 14 - Diferença da perspectiva processo interno no setor público e no setor privado ---------------- 42

Figura 15 - Diferença da perspectiva aprendizagem e crescimento no setor público e no setor privado---- $\quad 43$ 


\section{Lista de Tabelas}

Tabela 1 - Habilitação acadêmica dos respondentes por categoria profissional _-_______ 52

Tabela 2 - Comparação entre os grupos de escolaridade para a missão _-_ 54

Tabela 3 - Comparação entre os grupos de escolaridade para a visão -__________-_ 54

Tabela 4- Comparação entre os grupos de escolaridade para os indicadores_____________ 55

Tabela 5- Comparação entre os grupos de escolaridade para o conhecimento da existência de mecanismos que permitam acompanhar e avaliar a evolução da estratégia -- 55

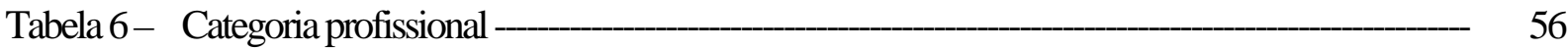

Tabela 7 - Conhecimento do plano estratégico daFUB____ 56

Tabela 8 - Conhecimento do plano estratégico do CESPE _-_ 56

Tabela 9- O estabelecimento de um plano estratégico pode melhorar as relações internas do trabalho --- 57

Tabela 10 - Habilitações acadêmicas - plano das relações internas do trabalho__________ 57

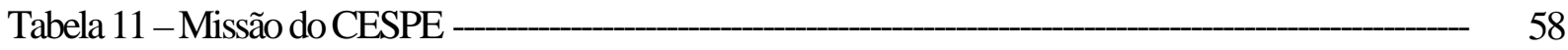

Tabela 12 - Visão -

Tabela 13 - Indicadores na perspectiva financeira de Kaplan e Norton (1997) escolhidos pelo CESPE --- $\quad 60$

Tabela 14 - Indicadores na perspectiva Cliente de Kaplan e Norton (1997) escolhidos para o CESPE ---- $\quad 60$

Tabela 15 - Indicadores na perspectiva processos internos de Kaplan e Norton (1977) escolhidos para o

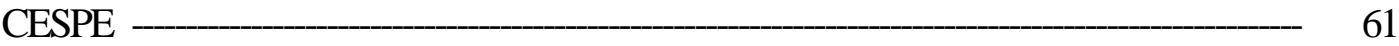

Tabela 16 - Indicadores na perspectiva aprendizagem e crescimento de Kaplan e Norton (1977) escolhidos para o CESPE ___ 61 


\section{Lista de Quadros}

Quadro 1 - Planejamento Institucional da FUB --o- 27

Quadro 2 - Resultado da implantação do BSC na SIEMENS e OXITENO

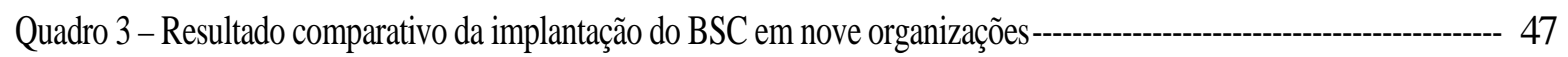




\section{SUMÁRIO}

1. INTRODUÇÃOO- 9

1.1 Formulação do Problema de Pesquisa --------------- 10

1.2 Objetivos 12

1.2.1 Objetivo Geral 12

2.2.2 Objetivos Específicos - 12

1.3 Justificativa-- 13

2 REFERENCIAL TEÓRICO- 14

2.1 Conceitos Básicos de Planejamento Estratégico------------------------------ 14

2.2 Contextualização Histórica do Balanced Scorecard (BSC) - 19

2.3 Conceito Básicodo BSC - 20

2.4 Perspectivas do BSC $-{ }_{-1}-{ }_{-1}$

3. FUB: PLANEJAMENTOESTRATÉGICO- 27

$3.1 \quad$ Histórico ----о- 29

3.2 Estrutura organizacional do CESPE/UnB- 34

3.3 Fluxo da Contratação de Concurso Público no CESPE/UnB, com base no BSC -.--_- 35

$3.4 \quad$ Dados de Entrada de Projetos no CESPE/UnB -

4. APLICAÇÃO DO BSC À ADMINISTRAÇÃO PÚBLICA-_ 40

5. APLICAÇÃODOBSC ÀS EMPRESAS-___ 40

6. METODOLOGIA-___ 50

$6.1 \quad$ Tipo de Pesquisa - 50

6.2 Participantes da Pesquisa ----_- 50

6.3 Instrumento - - 51

$6.4 \quad$ Roteiro de Entrevista -

6.5 Procedimentos - 51

$7 . \quad$ RESULTADOS -- 52

7.1 Definição e Caracterização da População -----o 52

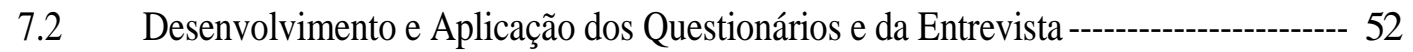

7.3 Análise e tratamento dos Dados- 53

7.4 Caracterização da Amostra--o- 55

7.5 O Plano Estratégico da FUB e do CESPE--- 56

7.6 Missão-

7.7 Visão---o- 58

7.8 Mecanismo de Acompanhamento e Avaliação da Estratégia --ב-_- 59

7.9 Indicadores para o BSC- 59

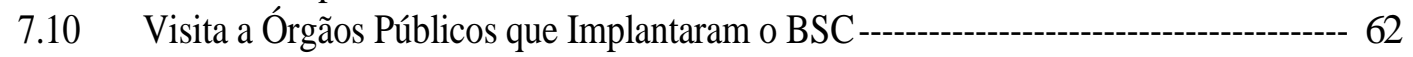

7.10.1 A Experiência do Banco do Brasil - --o 62

7.10.2 A Experiência da EMBRAPA --- 64

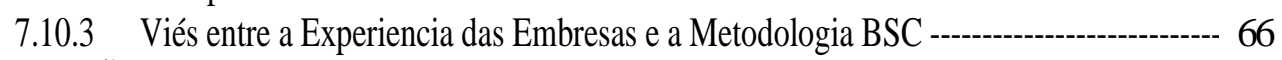

8. CONSIDERAÇÕESFINAIS -ב-ב- 69

REFERÊNCIAS

ANEXOS 


\section{INTRODUÇÃO}

Tempos de mudanças, dirão alguns, difíceis, dirão outros, outros ainda dirão instáveis, outros, desafiadores, incertos... A única certeza que se tem, em face da inconstância do presente e da incerteza do futuro, é a de que dos gestores, sejam eles públicos ou privados, muito será exigido. A velocidade da informação, as mudanças na tecnologia do comércio e da indústria nos levam a buscar novas e melhores soluções para as diversas situações que se pode enfrentar em nosso dia-a-dia. Precisa-se rever sempre paradigmas, conceitos, idéias.

Na nova economia, o capital humano assume importância fundamental na criação de valor. As organizações modernas tomam suas decisões com base não só nos resultados dos ativos tangíveis (máquinas, equipamentos, prédios etc.), mas, principalmente, nos resultados de seus ativos intangíveis (marcas, patentes, concessões públicas, capital intelectual, franquias, direitos autorais etc.), estes considerados por Kaplan como ativos singulares, cujas características únicas poderiam permitir a diferenciação entre as empresas e a obtenção de vantagens competitivas, assunto este que se reveste de especial destaque.

Perez e Famá (2006), que fizeram uma pesquisa com um universo de 699 empresas nos Estados Unidos da América (EUA), puderam comprovar na prática, por meio de testes estatísticos, o que diz a teoria disponível acerca de ativos intangíveis que geram valor ao acionista. Confirmam eles que investimentos em ativos intangíveis criam valor na empresa, estimulam o seu crescimento por meio de novos investimentos e contribuem para o incremento da riqueza dos acionistas.

Ampliam-se, portanto, as preocupações dos gestores no que diz respeito à capacitação de recursos humanos $(\mathrm{RH})$. $\mathrm{O}$ desenvolvimento de competências em planejamento, trabalho em equipe, comunicação, liderança, negociação, relacionamento interpessoal, entre outros, devem fazer parte das ações de capacitação dos RH, nas empresas modernas e competitivas de hoje.

A globalização, paralelamente, ampliou a oferta e a demanda por serviços com base em competências, forçou as organizações ao aprimoramento da qualidade dos seus produtos e do perfil dos profissionais prestadores de serviço. Tomadores de serviços, por outro lado, devem estar sempre atentos aos aspectos de avaliação dos resultados, não só de eficiência, mas sobretudo à eficácia das ações de treinamento e desenvolvimento de pessoal.

O Balanced Scorecard (BSC) é um conjunto integrado de indicadores equilibrados, que proporciona aos gestores abordagens de avaliação de performance (medidas de desempenho), derivadas da estratégia da organização e utilizados para mensurar, quantificar e dar suporte ao 
gerenciamento organizacional. Por meio dos resultados que se obtém, com a aplicação deste instrumento, segundo a literatura disponível, é possível verificar que as pessoas são o recurso mais valioso e capaz de impulsionar as organizações para maiores e melhores resultados de desempenho.

Segundo Moreira; Sedrani e Lima (2005), em 1992, Robert Kaplan - professor da Harvard Business School - e David Norton - consultor de empresas que liderou estudos de pesquisa em consultoria - , com base em hipóteses de performance que definiam indicadores financeiros como forma de criar valor de futuro nas organizações, publicaram artigo intitulado "Balanced Scorecard - Indicadores que impulsionam o desempenho", na Harvard Business Review. Com base nesse postulado, lançaram eles os fundamentos para a estruturação de um novo modelo de gestão estratégica.

De acordo com Kaplan e Norton (1997), a aplicação do BSC e de seus indicadores requer a adoção de estratégias embasadas em indicadores balanceados nas quatro perspectivas (financeira, clientes, processos internos e aprendizado e crescimento). Quando essas perspectivas não existem na estratégia da empresa, pode-se supor que elas existam e assim fazer uso do BSC.

\subsection{Formulação do problema de pesquisa}

No serviço público, as preocupações de gestão estão associadas aos riscos do descumprimento das leis que regem o setor. Tal preocupação seria de bom alvitre se não viessem acompanhadas de uma espécie de indiferença a critérios complementares também relacionados à gestão objetiva e racional.

A Fundação Universidade de Brasília (FUB) não é uma ilha nesse oceano. O seu modelo vigente de planejamento estratégico, delineado pelo Ministério da Educação e imposto a todas as universidades públicas, apóia-se em indicadores contábeis e financeiros, e visa substancialmente monitorar a alocação eficiente do capital físico e financeiro, bem como o sistema de controle da execução orçamentária, primando mais pelo "como fazer" sem ferir as normas que regem os serviços públicos, que pelo desenvolvimento dos ativos intangíveis, presentes na missão da Universidade, que é, falando-se de forma abrangente, produzir, aplicar, preservar e difundir idéias e conhecimentos.

Produzir, aplicar, preservar e difundir idéias e conhecimentos, pesquisar, propor soluções e abrir caminhos para a sociedade, atuando como um centro dinâmico de progresso e desenvolvimento regional, nacional e mundial, comprometido com a formação profissional de alta qualificação de cidadãos éticos, socialmente responsáveis e com visão à frente do seu tempo (Fundação Universidade de Brasília. Secretaria de Planejamento. Plano de Desenvolvimento Institucional FUB 20022006, Brasília, 2005. Relatório). 
Segundo Moreira; Sedrani e Lima (2005, p.1-4) o BSC mais que um "medidor de desempenho" é um Sistema de Gestão Estratégica cujo principal diferencial é reconhecer que os indicadores financeiros, por si só, não são suficientes para medir o desempenho da instituição proporcionando ao gestor uma visão de futuro. O BSC complementa as medições financeiras com avaliações relativas à satisfação do cliente, identificando os processos internos que devem ser aprimorados e analisa as possibilidades de aprendizado e crescimento, assim como os investimentos em recursos humanos, tecnologia e capacitação que poderão mudar substancialmente as atividades, impulsionando o crescimento futuro.

Kaplan e Norton (1997) enfatizam que é preciso, primeiramente, dar conhecimento a todos da estratégia adotada pela empresa, do auxiliar de serviços ao homem chave da instituição, com a finalidade de alcançar um fim, por meio de metas que serão atingidas paulatinamente. Todos precisam saber como o seu trabalho se insere no contexto institucional e de que forma a sua competência pessoal e profissional poderá contribuir para a consecução dos objetivos da empresa e que o conhecimento que ele(a) possui será muito bem-vindo à organização.

Segundo os mesmos autores, o trabalho deverá ser concebido de forma que a instituição seja engrandecida com o trabalho das pessoas e que, da mesma forma, a instituição preveja em seu orçamento uma recompensa, seja ela de cunho monetário, cultural, profissional ou de aprendizado pessoal, com a finalidade de retribuir, em contrapartida, o trabalho do funcionário. A situação ideal é que cada indivíduo dentro da organização tenha metas convergentes para os objetivos da instituição (metas pessoais vinculadas a recompensas) pois se não houver recompensas que possam ser alcançadas, o plano estratégico poderá ser desestimulante e vir a não funcionar. É preciso também que haja um alinhamento das metas do setor de trabalho, convergentes com os objetivos institucionais (cadeia que deve ser reconhecida).

Consideram, ainda, Kaplan e Norton (1997) que o alinhamento das iniciativas deve estar acompanhado dos recursos para que sejam efetivamente implantadas. As metas destacadas dentro das iniciativas propostas, denominadas marcos de referência, devem ser divulgadas oportunamente para que as pessoas tenham uma referência do desenrolar do plano de desenvolvimento ou plano estratégico — desde que seja algo importante a ser comunicado.

A partir dessa visão do BSC, resolveu-se investigar o seguinte problema de pesquisa: Viabilidade da aplicação do Balanced Scorecard em uma universidade pública: 


\section{análise de uma unidade descentralizada da Universidade de Brasília (UnB).}

Por imperativo da exigüidade do tempo, não será possível tomar por base a Fundação Universidade de Brasília como um todo para apoiar as conclusões do presente estudo. Optou-se então pela escolha de uma das suas unidades administrativas descentralizadas, tendo a escolha recaído sobre o CESPE/UnB, por ser essa unidade a melhor alternativa em termos de representatividade da instituição, tanto pelo seu forte vínculo com a área acadêmica quanto pela estrutura administrativa e de logística, que dão asas a sua vocação de órgão captador de recursos, bem como o faz reconhecido como um dos principais esteios propulsores da FUB.

\subsection{OBJETIVOS}

\subsubsection{Objetivo Geral}

O objetivo desta pesquisa é investigar a aplicabilidade da metodologia do BSC em uma unidade descentralizada da Universidade de Brasília (UnB).

Pretende-se analisar o impacto da nova metodologia no desempenho global do Centro de Seleção e Promoção de Eventos (CESPE/UnB), considerando ser essa uma das principais unidades captadoras de recursos da FUB.

\subsubsection{Objetivos Específicos}

Como objetivos específicos pretende-se:

a) analisar a estrutura existente atualmente no CESPE;

b) realizar o levantamento de alguns indicadores estratégicos mais comuns, verificar sua aplicabilidade no CESPE e sua correlação com os indicadores do BSC;

c) visitar a EMBRAPA e o Banco do Brasil, para analisar a experiência daquelas organizações relacionada com a implantação do Balanced Scorecard;

d) propor novos indicadores de avaliação que permitam a melhor mensuração do desempenho do CESPE, baseado na metodologia do balanced scorecard. 


\subsection{Justificativa}

O sistema de mensuração de desempenho adotado no planejamento estratégico da FUB se reveste das características tradicionais aplicáveis a todas as universidades públicas brasileiras, sem privilegiar as especificidades que fazem das universidades organizações diferenciadas. Carece, portanto, no modelo atual de gestão, de uma nova fórmula que contemple não só os ativos tangíveis como os intangíveis na mensuração do desempenho. Foi por este motivo que se optou por estudar a metodologia do "Balanced Scorecard", com vistas a fazer o cotejamento com o modelo vigente na FUB e verificar a viabilidade de se utilizar um modelo alternativo de planejamento estratégico que contemple a diversidade na universidade pública.

No presente estudo é dado enfoque aos novos indicadores que aparecem no BSC e que fazem parte da rotina administrativa dos gerentes e gestores. O BSC possui indicadores eficientes e eficazes, que avaliam os processos internos e externos, bem como mensuram as necessidades de investimento em capital humano e recursos tecnológicos, incrementando as atividades e melhorando o desempenho futuro da organização. 


\section{REFERENCIAL TEÓRICO}

\subsection{Conceitos Básicos de Planejamento Estratégico}

O Planejamento Estratégico é uma ferramenta que permite a organização compreender e responder adequadamente às mudanças que estejam ocorrendo ou que estejam em vias de ocorrer no seu ambiente externo. O Planejamento Estratégico, portanto, aparelha a organização para o enfrentamento das turbulências do mercado, dando-lhe sustentabilidade.

Oliveira (2004, p.344) define o Planejamento Estratégico como um processo administrativo que proporciona sustentação metodológica para se estabelecer a melhor direção a ser seguida pela empresa, com vistas a obter um ótimo grau de interação com o ambiente, atuando de forma inovadora e diferenciada.

O Planejamento Estratégico é de responsabilidade dos níveis executivos da empresa e se refere à formulação de objetivos a serem seguidos e ao rumo e direção a serem tomados, levando sempre em consideração as condições internas e externas da empresa, bem como a evolução esperada.

Para que seja definido de forma correta, o planejamento estratégico deve ser realizado com precisão e em conformidade com a missão da empresa e com o entendimento prévio do que se espera desse planejamento. Ainda segundo Oliveira (2004), uma empresa espera do planejamento estratégico:

- conhecer e aperfeiçoar a utilização de seus pontos fortes e suas vantagens operacionais para desenvolver a maneira mais apropriada e vantajosa de utilizá-los, pois eles proporcionam uma grande vantagem ao ambiente empresarial;

- descobrir seus pontos fracos e eliminá-los ou minimizá-los, já que são variáveis controláveis e que proporcionam desvantagem competitiva;

- conhecer e aproveitar as oportunidades externas que possam favorecer suas ações estratégicas. As oportunidades externas constituem uma força ambiental incontrolável, mas somente favorecem a empresa quando são conhecidas;

- identificar as ameaças e os obstáculos em tempo hábil para tomada de providências. As ameaças também são forças ambientais incontroláveis pela empresa, mas, desde que conhecidas, poderão ser evitadas;

- desenvolver um plano de trabalho que apresente as premissas básicas que deverão ser consideradas; as expectativas da empresa; os caminhos que deverão ser seguidos, 
incluindo os possíveis caminhos alternativos em caso de necessidade; planos de ação detalhados, que apresentem informações como o quê, como, quando, por quem, para quem, por que e onde estes planos de ação devem ser utilizados, e alocação de recursos.

Portanto, o planejamento estratégico, conforme Oliveira (2004) deve apresentar um correto direcionamento de esforços para pontos comuns a forma detalhada do que deve ser feito pela empresa; o entendimento de todos em relação à missão da empresa, aos propósitos a que se destina, às macroestratégias, às macropolíticas, à postura estratégica, aos objetivos funcionais e gerais, aos desafios, às metas políticas e aos projetos da empresa, além de estabelecer um período factível de execução, levando em consideração as prioridades estabelecidas e as exceções.

Segundo Chiavenato e Sapiro (2003, p.39), "o planejamento estratégico é a formulação de estratégias organizacionais no qual se busca a inserção da organização e de sua missão no ambiente em que ela está atuando”. (Drucker, 1984, p.133-136 apud Chiavenato e Sapiro, 2003, p.39), define planejamento estratégico da seguinte forma:

É o processo contínuo de, sistematicamente e com o maior conhecimento possível do futuro contido, tomar decisões atuais que envolvem riscos; organizar sistematicamente as atividades necessárias à execução dessas decisões e, através de uma retroalimentação organizada e sistemática, medir o resultado dessas decisões em confronto com as expectativas alimentadas.

Marcelino (2003, p.71) conceitua estratégia como um “conjunto coerente e sistêmico de prioridades e regras de decisão que orientam o desenvolvimento e a construção do futuro de uma organização num horizonte de médio e longo prazo".

O planejamento estratégico é responsável por transformar os planos da empresa em realidade, por isso deve ser muito bem detalhado, de forma a garantir que as informações importantes indiquem aos executivos o caminho necessário a seguir. Desdobram-se em

- Táticas - estratégias que funcionam em médio prazo, permitindo realinhamentos para imediata obtenção de objetivos limitados. Referem-se a cada departamento ou unidade da organização e seu foco é no médio prazo, ou seja, no exercício anual.

- Planos operacionais: que é um desdobramento do plano tático, com foco na tarefa ou atividade e no curto prazo. 


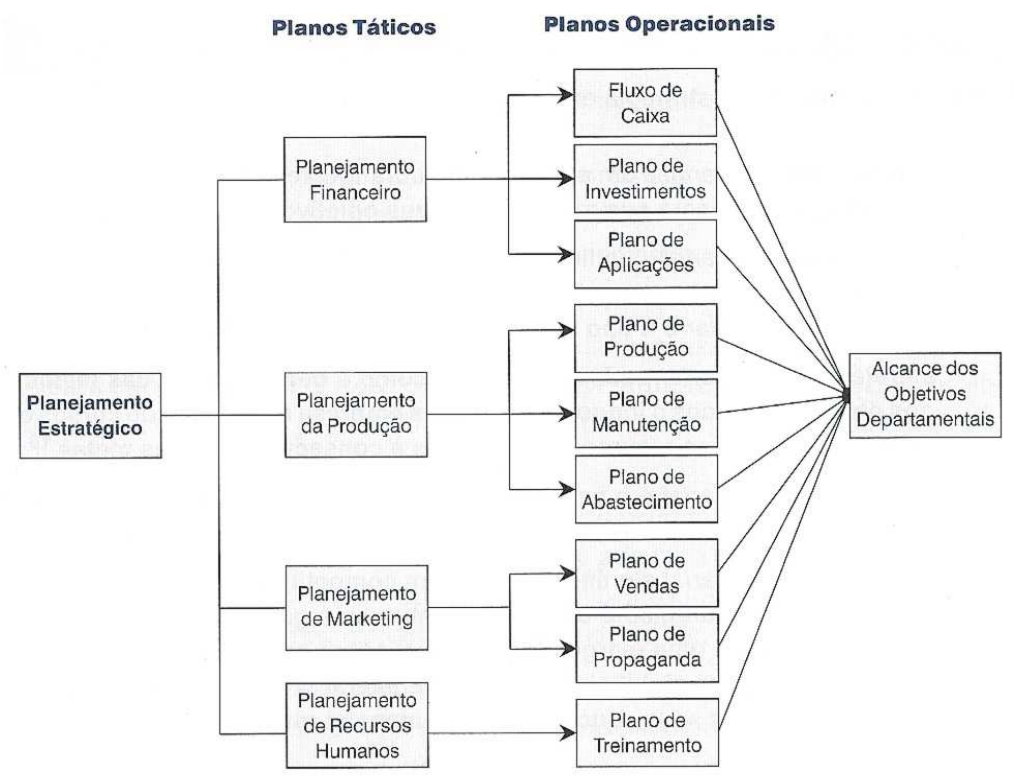

Figura 1 - Planos Táticos e Operacionais decorrentes do Planejamento estratégico Fonte: Chiavenato e Sapiro, 2003, p.40.

Segundo Chiavenato e Sapiro (2003), são atribuídos ao processo de planejamento os seguintes elementos:

1. Declaração da missão: define o "negócio", delimitando seu ambiente de atuação. A missão da organização representa sua razão de ser, o seu papel na sociedade. Esta definição antecede o diagnóstico estratégico.

2. Visão de negócios: mostra uma imagem da organização no momento da realização de seus propósitos no futuro. Isto não se trata de predizer o futuro, mas garanti-lo no presente. A visão de negócios associada a uma declaração da missão compõe a intenção estratégica da organização.

3. Diagnóstico estratégico externo: procura antecipar oportunidades e ameaças para a concretização da visão, da missão e dos objetivos da empresa. Analisa as diferentes dimensões que influenciam as organizações e também estuda as dimensões setoriais e competitivas. A análise competitiva está baseada nas cinco forças que atuam sobre a organização: o poder de barganha dos clientes e fornecedores; a ameaça dos produtos substitutos; os novos concorrentes entrantes e a rivalidade dos atuais concorrentes.

4. Diagnóstico estratégico interno: diagnostica a situação da organização perante as dinâmicas ambientais, suas forças e fraquezas, criando assim as condições para formulação de estratégias que representam a melhor posição da empresa no ambiente em que ela atua. As premissas para a construção dos cenários estão embasadas no diagnóstico externo e interno. 
5. Fatores-chave de sucesso: evidencia questões realmente críticas para a organização, emergindo dos elementos apontados na análise realizada com a aplicação do modelo SWOT, de cuja solução dependerá a consecução da missão. A função do modelo SWOT é cruzar as ameaças e oportunidades externas à organização com seus pontos fortes e fracos. Desse cruzamento surge uma matriz com quatro células, e para cada célula haverá uma indicação de que rumo tomar. Os determinantes do sucesso, também conhecidos como fatores críticos de sucesso, encaminham as políticas de negócios.

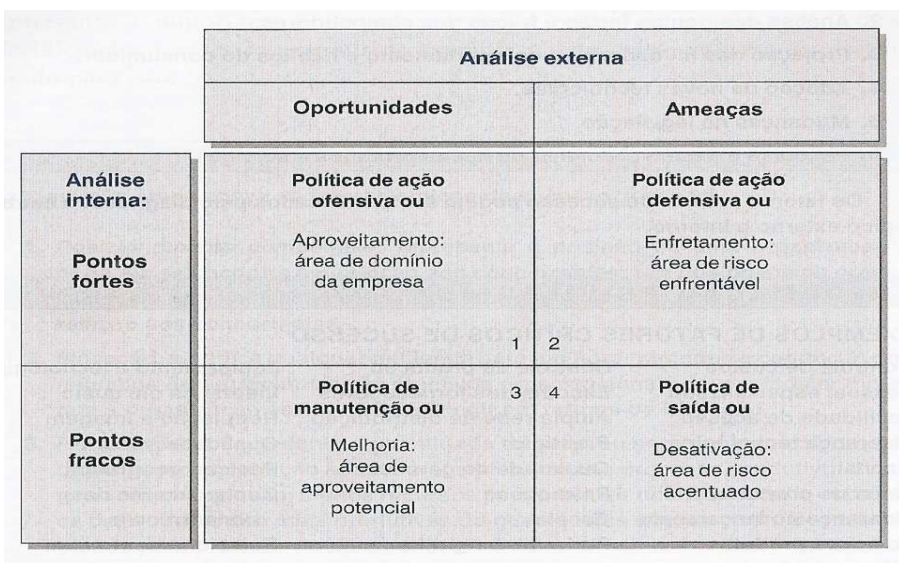

Figura 2 - As quatro zonas na matriz SWOT Fonte: Chiavenato e Sapiro, 2003, p.188.

6. Sistemas de planejamento estratégico: tem como propósito formular estratégias e sua implementação pelo processo de construção das ações segundo as quais a organização perseguirá o conseguimento de sua visão de negócios, sua missão e seus objetivos e de sua implementação por meio de planos operacionais (também chamados de programas táticos)

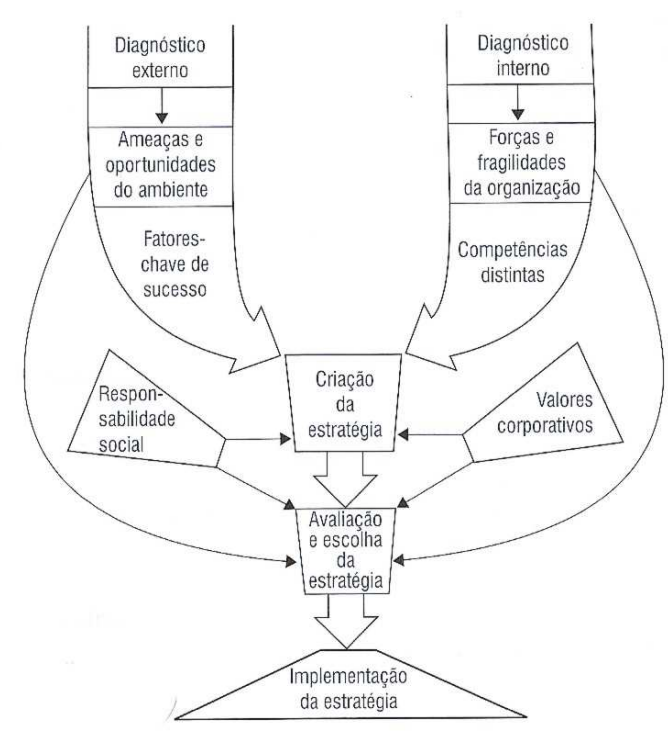

Figura 3 - Concepção do modelo básico de planejamento estratégico Fonte: Chiavenato e Sapiro, 2003 p.43. 
7. Definição dos objetivos: a organização persegue simultaneamente diferentes objetivos em uma hierarquia de importância, de prioridades ou de urgência.

8. Análise dos públicos de interesse (stakeholders): o stakeholder é uma pessoa, grupo de pessoas ou organização - como consumidores, usuários, empregados, proprietários, dirigentes, governos, instituições financeiras, opinião pública, acionistas. A análise consiste na identificação dos grupos de interesse e poderes de influência com respeito à missão da organização.

9. Formalização do plano: é um plano para a ação, com base nas estratégias escolhidas. Para sua implementação é necessário fazê-lo por meio de programas e projetos específicos. Requer um grande esforço de pessoal e emprego de modelos analíticos para a avaliação, a alocação e o controle dos recursos. Todas as áreas deverão ser envolvidas na tomada de decisão da organização e um firme controle sobre o trabalho deve ser exercido.

10. Auditoria de desempenho e resultados (reavaliação estratégica): fazer uma revisão do que foi implementado para decidir os novos rumos do processo, mantendo as estratégias implantadas com sucesso e revendo aquelas que se mostrarem equivocadas.

Ainda de acordo com os autores, o processo de planejamento estratégico deve ser elaborado de maneira integrada e articulada, de forma a integrar os planos táticos e operacionais da empresa, maximizando resultados, minimizando as deficiências e se utilizando de princípios de maior eficiência, eficácia e efetividade, pois são estes os principais critérios de avaliação da gestão.

\begin{tabular}{|c|c|c|c|c|c|}
\hline & EFICIÊNCIA É & & EFICÁCIA É & & EFETIVIDADE É \\
\hline$*$ & $\begin{array}{l}\text { Fazer as coisas da } \\
\text { maneira adequada }\end{array}$ & 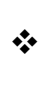 & Fazer as coisas certas & $*$ & $\begin{array}{l}\text { Manter-se sustentável no } \\
\text { ambiente }\end{array}$ \\
\hline$\nLeftarrow$ & Resolver problemas & $\nLeftarrow$ & $\begin{array}{l}\text { Produzir alternativas } \\
\text { criativas }\end{array}$ & $\nLeftarrow$ & $\begin{array}{l}\text { Apresentar resultados } \\
\text { globais ao longo do tempo }\end{array}$ \\
\hline$\nLeftarrow$ & $\begin{array}{l}\text { Cuidar dos recursos } \\
\text { aplicados }\end{array}$ & 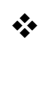 & $\begin{array}{l}\text { Maximizar a utilização dos } \\
\text { recursos }\end{array}$ & $\star$ & $\begin{array}{l}\text { Coordenar esforços e } \\
\text { energias sistematicamente }\end{array}$ \\
\hline$*$ & Cumprir o dever & $\nLeftarrow$ & Obter resultados & & \\
\hline$\nLeftarrow$ & Reduzir custos & $\nLeftarrow$ & Aumentar o lucro & & \\
\hline
\end{tabular}

Figura 4 - Princípios de eficiência, eficácia e efetividade

Fonte: Chiavenato e Sapiro, 2003, p.40. 


\subsection{Contextualização Histórica do BSC}

Em 1992, o Professor Robert Kaplan, da Harvard Business School, e o consultor de empresas David Norton publicaram o artigo "Balanced Scorecard - Indicadores que impulsionam o desempenho", criando assim os fundamentos para a estruturação do novo modelo de gestão estratégica. Desde então, esses princípios vêm sendo aplicados com sucesso no mundo inteiro, em centenas de organizações, tanto do setor público como do setor privado, bem como em organizações sem fins lucrativos e não-governamentais.

Segundo estudos da Symnetics Business Transformation [on-line]: disponível em: 〈http://www.symnetics.com.br/bscr.asp>, acesso em 20/04/2007, cinqüenta por cento das empresas que compõem a lista da renomada revista Fortune, se utilizam do sistema de gestão estratégica do BSC, tanto nos Estados Unidos da América (EUA) como na Europa. Outro dado interessante do BSC é que ele foi escolhido pela renomada revista Harvard Business Review, como uma das práticas de gestão mais revolucionária dos últimos 75 anos. $\mathrm{O}$ Primeiro Comitê Temático do Prêmio Nacional de Qualidade (PNQ) elegeu o BSC como uma das ferramentas de gestão para a excelência empresarial, pois ele contribui com aproximadamente 580 pontos nos critérios de excelência do PNQ. Outro dado contido na página da internet acima referenciada é que grandes empresas brasileiras fazem uso do BSC como ferramenta estratégica tais como a Gerdau, Aracruz, Basil Telecom, Camargo Corrêa, Mercedes Bens, Petrobrás, dentre outras.

Dez anos depois de lançar o 1. ' livro do "Balanced Scorecard", os autores Kaplan e Norton finalmente encontram a gestão do conhecimento. Embora desde a introdução do trabalho BSC, que trouxe novas idéias e que os consagraram internacionalmente, estes autores já destacavam a importância da dimensão do aprendizado e crescimento, foi apenas em seu último livro que esta perspectiva, bem como a questão dos intangíveis, passou a ser ponto central na argumentação desses autores. Os ativos intangíveis, o conhecimento tácito (que o sujeito adquire ao longo da vida, é subjetivo, não mensurável e difícil de ser explicado aos outros) e explícito (fácil de ser comunicado, tabulado, regulado, demonstrado) e a capacidade de aprendizado coletivo, segundo eles, são garantia da inovação e da diferenciação na obtenção da vantagem comercial e coletiva.

Segundo Pedro (2004), o BSC no setor público pressupõe visão horizontal dos processos estruturados que têm como característica principal o foco no cidadão e nas empresas. Embora seja um instrumento de gestão moderno e orientado à estratégia, muitas 
vezes o resultado não é o esperado, porque as organizações confundem o BSC com um mero conjunto de indicadores ajustados à informação disponível.

\subsection{Conceito básico do Balanced Scorecard.}

De acordo com Kaplan e Norton (1997) o Balanced Scorecard é uma ferramenta empresarial que traduz a missão e a estratégia da organização em um conjunto compreensível de medidas de desempenho, propiciando a formação de uma estrutura de mensuração estratégica e de um sistema de gestão eficiente.

Segundo os autores o BSC compreende, pois, um modelo de avaliação de desempenho, com base em diversas dimensões, o que o diferencia da análise fundamentada apenas em indicadores puramente financeiros. Por meio do BSC, a administração pode identificar o desempenho empresarial considerando os resultados da rentabilidade, dos custos, bem como dos indicadores das necessidades do atendimento dos clientes, da eficiência dos processos internos e do potencial de aprendizado e crescimento da empresa.

Ainda segundo os autores o principal diferencial do Balanced Scorecard é reconhecer que os indicadores financeiros não são suficientes para consolidar um processo de avaliação de desempenho com garantia de eficácia. Assim, podemos deduzir que sua vantagem em relação ao modelo tradicional consiste na adição de novos e necessários indicadores, como avaliação sobre o cliente, identificação dos processos internos carentes de aprimoramento, análises das possibilidades de aprendizado e crescimento, assim como análise dos investimentos em recursos humanos, tecnológicos e capacitações que, vias de regra, poderá mudar atividades rotineiras e impulsionar o desempenho futuro.

Ressaltam os autores que ao longo das últimas décadas, técnicas de gestão têm evoluído para atender às necessidades emergentes de acionistas, executivos e comunidade. No início do século, os sistemas de gestão do desempenho organizacional se baseavam em indicadores financeiros e contábeis, já que o paradigma de valor estava diretamente associado aos ativos tangíveis, (máquinas equipamentos, edifícios etc.). O referencial, no entanto, foi mudado e o valor de uma organização passou a ser medido, em grande parte, pelos seus ativos intangíveis (capacidade intelectual e de inovação, valor da marca, aptidão para implementar a estratégia, entre outras). Daí surgiu a grande questão: como gerenciar uma organização que tem grande parte do seu valor nos ativos intangíveis, utilizando um sistema de mensuração 
que privilegia apenas os valores tangíveis?

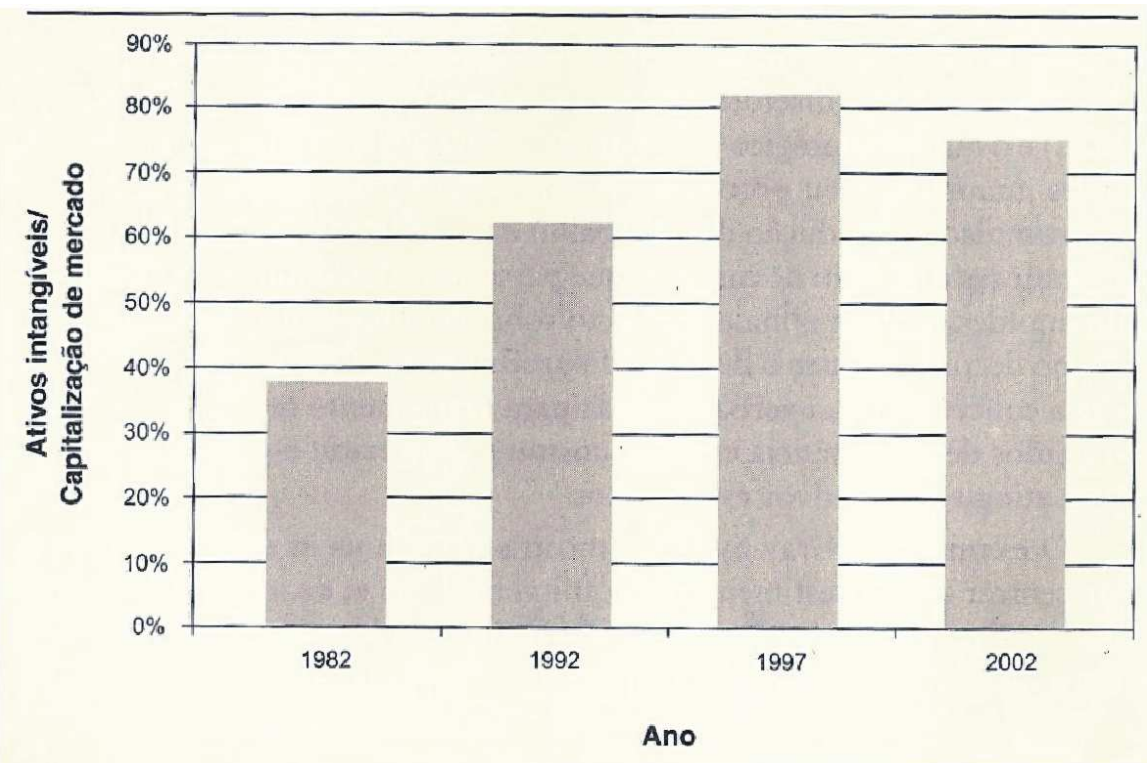

Figura 5 - Importância crescente dos ativos intangíveis Fonte: Kaplan e Norton, 2004, p.4

Grande é a quantidade de relatos e experiências de implantação do Balanced Scorecard ao redor do mundo, principalmente na Europa e nos Estados Unidos. A literatura apresenta relato de empresas não identificadas e de empresas consolidadas no mercado global, como a Xerox, o Citibank Private Bank, entre outros, que aderiram ao Balanced Scorecard. Apesar da falta de unanimidade em torno do BSC, seu primeiro livro foi traduzido para dezenove línguas.

\subsection{Perspectivas do Balanced Scorecard.}

Segundo Kaplan e Norton (1997), o Balanced Scorecard consiste em uma metodologia que liga as atividades de curto e longo prazo de uma organização, com base na visão, na missão e na estratégia delineada pela empresa, por meio do estabelecimento de metas confiáveis e mensuráveis, definidas por consenso.

Em que pese o presente estudo embasar sua aplicação prática em apenas uma das diversas unidades administrativas da FUB, sabe-se que a obtenção de resultados eficientes e globais com a metodologia do BSC requer que sua aplicação se dê no âmbito geral da organização, não apenas em um departamento, centro ou unidade, pois é improvável que a 
abordagem circunscrita a uma fração produza resultados globais. Entretanto, é viável a introdução da metodologia BSC a partir de uma unidade administrativa, expandindo-se para a totalidade da empresa.

Segundo Pedro (2004), a aplicação da metodologia do BSC demanda uma conscientização da situação vigente da organização, o que se pode obter a partir do seguinte questionamento:

- estamos satisfazendo os nossos clientes?

- os Grupos de Interesse (funcionários, gestão de topo, legisladores, fundadores e entidades de tutela do departamento em causa) estão satisfeitos e mostram estabilidade?

- está acontecendo alguma alteração com a base dos nossos clientes? A estratégia global adotada está funcionando? As estratégias individuais estão alinhadas com a estratégia global?

- somos eficientes? Estamos sendo eficazes em termos de quantidade e qualidade do serviço?

- os grupos de interesse estão contribuindo com idéias construtivas?

- estamos desenvolvendo as competências necessárias para executar as estratégias que definimos?

A ligação entre missão, visão e estratégia da organização é realizada por meio da identificação, em um primeiro momento, das ações a serem realizadas pela organização segundo as diretrizes aprovadas pela diretoria da empresa. Essas diretrizes devem estar relacionadas por uma cadeia de causas e efeitos, tendo como base as quatro perspectivas identificadas por Kaplan e Norton (1997) como essenciais para qualquer organização obter o verdadeiro crescimento e sucesso no longo prazo, a saber: 1) Financeira; 2) Clientes; 3 ) Processos internos e 4) Aprendizado e crescimento. 


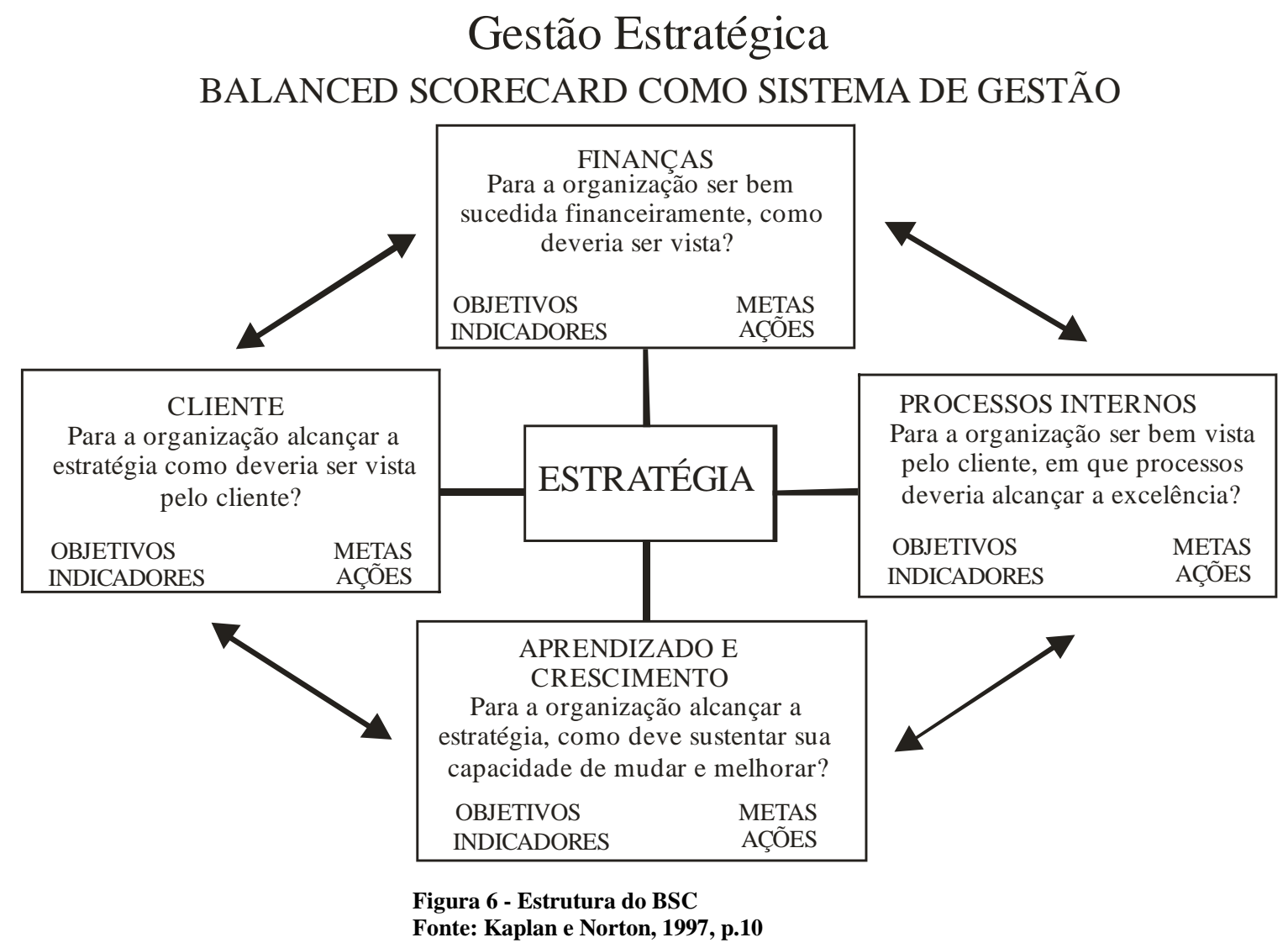

Analisando as perspectivas sob o ponto de vista de Kaplan e Norton (1997) temos:

A perspectiva FINANCEIRA ocupa o topo da figura porque na maioria das organizações o lucro representa o anseio maior, o objetivo principal. O BSC deve contar a história da estratégia, começando pelos objetivos financeiros de longo e médio prazo, relacionando-os depois à seqüência de ações que precisam ser tomadas em relação aos processos financeiros, dos clientes, dos processos internos e, por fim, dos funcionários e sistemas, a fim de que, no longo prazo, seja produzido o desempenho econômico desejado. Isto significa que todos os objetivos e medidas das outras perspectivas deverão estar associados à consecução de pelo menos um ou mais objetivos na perspectiva financeira.

Na perspectiva CLIENTES, as empresas identificam os segmentos de clientes e mercado nos quais desejam competir, pois os clientes representam as fontes de renda que irão produzir o componente de receita dos objetivos financeiros da empresa. Permitem também às empresas alinhar suas medidas de resultados relacionadas com os clientes — satisfação, fidelidade, retenção, captação e lucratividade - com segmentos específicos de clientes e mercado. As preferências dos clientes têm que ser percebidas a tempo de não perdê-los para o concorrente que atende às necessidades desses clientes. Portanto, podemos inferir que a perspectiva dos clientes traduz a missão e a estratégia da empresa em objetivos específicos 
para segmentos focalizados de clientes e mercados, que podem ser comunicados a toda organização.

A perspectiva PROCESSOS INTERNOS, objetiva identificar os processos mais críticos da empresa e melhorá-los para realizar os objetivos dos clientes e acionistas. É recomendável, com foco no BSC, que os executivos definam uma cadeia de valor completa dos processos internos que tenha início com o processo de inovação - identificação das necessidades atuais e futuras dos clientes e desenvolvimento de novas soluções para essas necessidades. Além de medir o desempenho, o controle, a análise da variação financeira e a melhoria do desempenho dos departamentos da empresa, os processos internos no BSC adotam medidas de qualidade, produção, produtividade e ciclo. Em passado mais recente foi incorporado o processo de inovação a esta perspectiva, onde se identifica as características do segmento de mercado que a empresa deseja atingir, para depois projetar e desenvolver produtos e serviços que satisfaçam a esses segmentos específicos. Para tanto as empresas devem aplicar recursos no desenvolvimento de pesquisas e depois projetar e desenvolver produtos e serviços que satisfaçam a esses segmentos específicos.

Na perspectiva de APRENDIZADO E CRESCIMENTO os objetivos são os vetores de resultados excelentes nas três primeiras perspectivas. No sistema contábil financeiro tradicional, o investimento no aumento da capacidade de pessoal, sistemas e processos organizacionais são tratados como despesas do exercício, de modo que a redução destes custos produz ganhos incrementais em curto prazo. Entretanto, esta atitude traz consequiências adversas em longo prazo, pois os efeitos da capacitação organizacional, funcionários e sistemas, não aparecem no curto prazo. O BSC enfatiza a importância de investir no futuro, não apenas nas áreas tradicionais - novos equipamentos, pesquisa e desenvolvimento de novos produtos —, mas também na infra-estrutura - capacitação de pessoal, sistemas e procedimentos — , para alcançar os objetivos ambiciosos de crescimento financeiro em longo prazo. As estratégias para um desempenho de qualidade superior geralmente exigem investimentos significativos em pessoal, sistemas e processos que produzam as capacidades organizacionais necessárias.

Quando integradas, estas quatro perspectivas proporcionam uma análise e uma visão ponderada da situação atual e futura do desenvolvimento do negócio. 


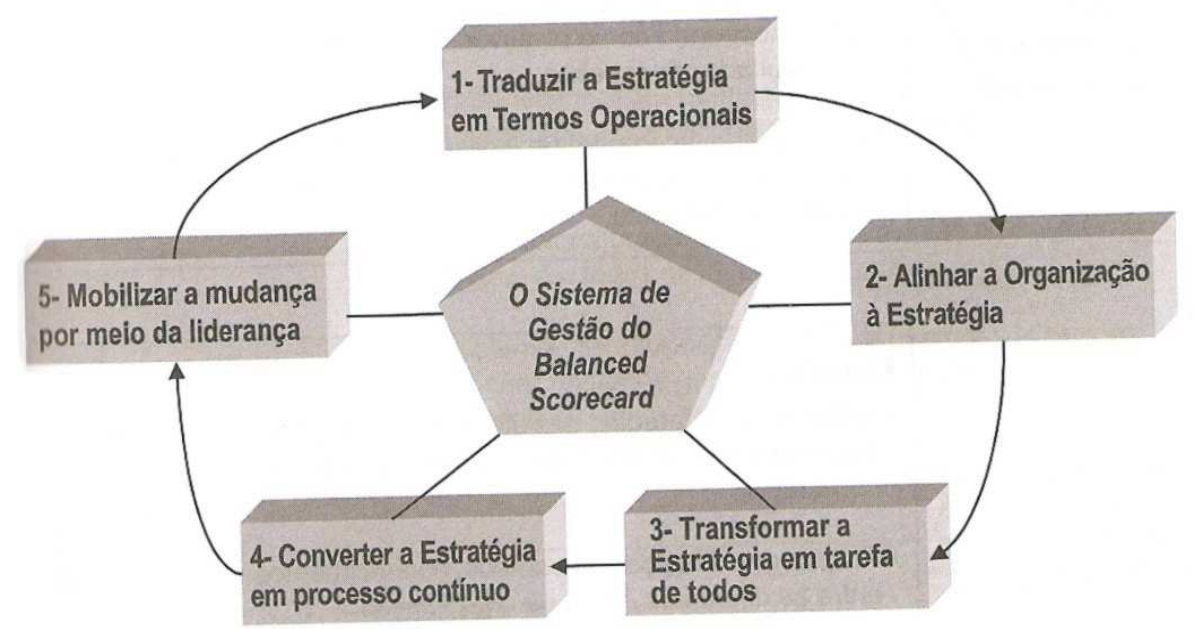

Figura 7 - Os princípios de uma organização orientada para a estratégia. Fonte: Herrero Filho, 2005, p.33.

Kaplan e Norton (2000) ressaltam cinco princípios, que denominaram "princípios da organização focalizada na estratégia" para se obter o alinhamento da estratégia:

- princípio 1: traduzir a estratégia em termos operacionais - com este princípio o BSC fornece uma receita para a criação de valor a longo prazo, para clientes e segmentos de mercado desejados. Este princípio combina utilização de recursos e capacidades internas. O BSC oferece ferramentas para descrever a estratégia e com isso cria um ponto de referência comum e compreensível para todos os empregados;

- princípio 2: alinhar a Organização à Estratégia - este princípio mostra como criar cooperação e ligações entre os diversos setores, diretorias e procura propiciar um clima onde o desempenho organizacional seja superior às estratégias individuais, buscando a quebra dos possíveis obstáculos funcionais das organizações;

- princípio 3: transformar a estratégia em tarefa de todos - o BSC é uma ferramenta no processo de comunicação e educação de todos, pois, de fácil compreensão, leva os recursos humanos a compreenderem bem o seu papel dentro da organização de modo a desempenhar as suas tarefas diárias voltadas para o êxito da estratégia;

- princípio 4: converter a estratégia em processo contínuo - o BSC mostra como transformar a estratégia em um processo continuado, faz a ponte da interação entre o gerenciamento tático, composto pelos orçamentos financeiros e avaliações mensais, e o gerenciamento estratégico. A implementação deste processo se faz a partir dos seguintes temas: a ligação da estratégia ao processo orçamentário; a prática de reuniões gerenciais para a avaliação da estratégia e, por último, a evolução para um processo de aprendizado e adequação da estratégia; 
- princípio 5: mobilizar a mudança por meio da liderança executiva: este princípio aponta que o processo mais importante para a obtenção do sucesso é o envolvimento de todos da equipe executiva; é o desenvolvimento, de forma gradual, de um sistema que coloca em prática novos valores e novas estruturas.

Estes cinco princípios nos deixam antever que a utilização do BSC provoca mudança de conduta e de desempenho, por meio de sistema gerencial que expressa a estratégia e ao mesmo tempo interliga todas as partes da organização. 


\section{FUB: PLANEJAMENTO ESTRATÉGICO}

De acordo com o Plano Anual de Atividades da FUB elaborado pela Secretaria de Planejamento da FUB (2006), o processo de planejamento abrange os níveis estratégico, tático e operacional.

O Planejamento Estratégico, elaborado pela Administração Central, define a missão, os valores, os objetivos e as diretrizes institucionais. O Planejamento Tático define os objetivos a serem alcançados, a longo e médio prazo, pelas unidades integradas do Sistema de Planejamento, e foram elaborados diretamente por institutos, faculdades, órgãos complementares, centros e secretarias e, em última instância pelos decanatos e secretarias. Esse nível de planejamento (tático) integra o primeiro (estratégico) e abrange todas as unidades da instituição.

O planejamento Operacional é atribuição das mesmas unidades participantes da fase anterior e das subunidades responsáveis pela implantação das atividades e projetos definidos. Neste caso, o horizonte temporal do planejamento operacional é anual, e o desempenho das unidades nessa etapa do planejamento norteia a divisão das verbas orçamentárias no âmbito da Universidade. O documento formal do planejamento Operacional da UnB é o Plano Anual de Atividades (PAA). No Planejamento Operacional, os planos elaborados são detalhados anualmente, configurando as metas a serem alcançadas em cada um dos projetos elaborados.

\section{Quadro 1 - Planejamento institucional da FUB -}

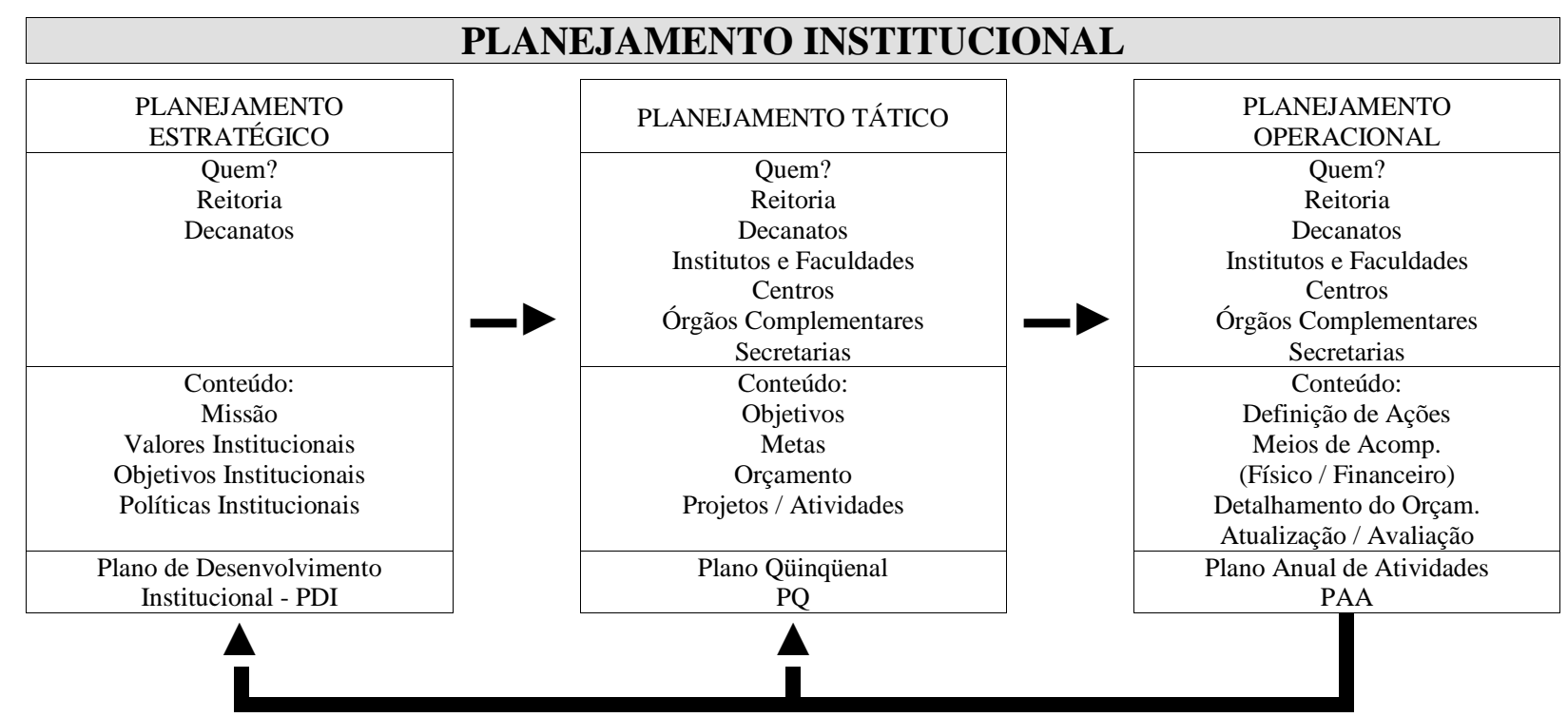

Fundação Universidade de Brasília. Secretaria de Planejamento. Estrutura e Fluxo de Atualização do Sistema de Planejamento da UnB. Brasília, 2005. Plano Anual de Atividades da FUB. Publicado 
Em síntese, o Sistema de Planejamento da UnB conta com cinco instrumentos: três estão relacionados à elaboração, à atualização e ao acompanhamento dos planos institucionais elaborados pelas unidades administrativas e acadêmicas (PDI, PQ e PAA) e dois referem-se à avaliação das atividades desenvolvidas, tanto pelas unidades quanto pela Instituição.

São instrumentos associados à elaboração do planejamento institucional e das unidades acadêmicas e administrativas:

a) Plano de desenvolvimento Institucional (PDI): contém as definições estratégicas da UnB e as metas a serem alcançadas a longo prazo. Serve de elemento orientador do planejamento institucional e como instrumento de divulgação, na comunidade, dos principais objetivos a serem alcançados. É aprovado pelo Conselho Universitário da UnB e pelo Conselho Diretor da FUB.

b) Plano Qüinqüienal (PQ): contém os projetos apresentados por todas as unidades. Estes projetos estão associados aos objetivos institucionais e metas institucionais de longo prazo, sendo geridos institucionalmente pelos responsáveis pelas dez áreas em que se estrutura o acompanhamento do planejamento, a médio e longo prazo. No PQ, os projetos e metas plurianuais das unidades são detalhadas em período anuais que permitem o acompanhamento e replanejamento dos projetos e atividades propostos. $\mathrm{O}$ Plano Qüinquienal é aprovado pelas mesmas instâncias do PDI e sua operacionalização deve ser o elemento chave na elaboração dos orçamentos anuais.

c) Plano Anual de Atividades (PAA): Consiste no detalhamento de objetivos e metas previstos para cada ano. Sua primeira versão é elaborada simultaneamente no PDI e no PQ da instituição. Ao final de cada exercício, a avaliação e a reestruturação do PQ permitem a atualização dos Planos Anuais subsequientes. O PAA do primeiro exercício do qüinquiênio é utilizado na definição da linha de financiamento dos projetos aprovados pelas unidades. As mudanças subseqüentes são acompanhadas pela Câmara de Administração e Finanças.

d) Matriz de Planejamento (MP): documento sintético usado para garantir a consistência das bases do Planejamento Estratégico da UnB, serve como orientador na classificação dos projetos idealizados pelas unidades, em relação à proposta global da Universidade.

e) Matriz de Indicadores Institucionais (MI): em fase de definição e implantação. Essa matriz deve conter os indicadores gerais relativos aos objetivos e áreas de planejamento institucional. Os indicadores permitirão a avaliação da performance das 
diversas unidades, garantindo a homogeneidade de avaliação às diversas unidades integrantes do Sistema de Planejamento da Universidade.

Ademais, existem outros instrumentos associados ao acompanhamento do planejamento da UnB e de suas unidades, a saber:

a) Relatórios Trimestrais de Planejamento (RTP);

b) Relatório Anual de Gestão;

c) Seminário de Avaliação de Planejamento e

d) Relatórios de Avaliação Plurianual.

O sistema de Planejamento Institucional prevê revisões de grande porte ao final de cada qüinqüênio de planejamento. Ao longo do período, no entanto, são feitas mudanças e revisões anuais, que contemplam desde a alteração dos valores previstos até a inclusão de novos objetivos. A idéia é que tanto os sistemas e os instrumentos de planejamento, quanto as propostas da Universidade e de suas unidades sejam permanentemente revistas, garantindo-se, assim, a flexibilidade e adaptabilidade do planejamento, que só assim poderá embasar um eficiente sistema de gestão universitária.

\subsection{Histórico}

No dia 15 de dezembro de 1961, o então Presidente João Goulart, assina a lei que cria a Fundação Universidade de Brasília (FUB), como entidade autônoma, mantenedora da Universidade de Brasília (UnB), com enorme patrimônio próprio, constituído por prédios, terrenos de superquadras urbanas, terrenos destinados à construção da universidade, além de significativo aporte de recursos, sob a forma de dotação global para manutenção da FUB, isenção de impostos, direitos e taxas alfandegárias, bem como gozo de autonomia didática, administrativa, financeira e disciplinar.

A recomendação ao projeto que instituiu a Fundação Universidade de Brasília,

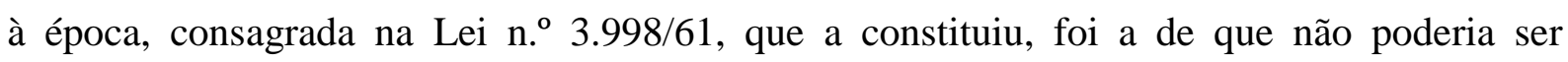
estruturada na forma de autarquia, pois esta estrutura não asseguraria a indispensável autonomia da instituição, concebida para ter caráter de alta relevância nacional.

As decisões da UnB são emanadas dos seus três conselhos: Conselho Superior Universitário (CONSUNI); Conselho de Ensino, Pesquisa e Extensão (CEPE) e Conselho de Administração (CAD), dos quais participam, na sua constituição, docentes, técnico- 
administrativos e alunos, garantindo assim a participação da comunidade nas instâncias decisórias superiores.

O primeiro vestibular da UnB foi realizado nos dias 26 e 27 de fevereiro de 1962, nos colégios Elefante Branco e Ginásio do Centro de Ensino Fundamental - CASEB, pois não havia nenhuma edificação concluída no campus da $\mathrm{UnB}$, que foi inaugurado quase dois meses depois, no dia 20 de abril de 1962, na gestão do Reitor Darcy Ribeiro.

Outros vestibulares se sucederam a este, em moldes semelhantes, organizados pela Secretaria-Geral dos Cursos da UnB.

Ao final da década de 60, as provas e o concurso passaram a ser de responsabilidade das comissões designadas para o fim específico de realizar o vestibular, compostas por professores de várias especialidades e por funcionários escolhidos e designados para executar tal tarefa, sem a preocupação de torná-lo um trabalho continuado. Com o crescimento do número de candidatos no Brasil - de 71.000 candidatos em 1962, esse número cresceu para 678.000 candidatos em 1975 -, o vestibular ganhou contorno de problema nacional.

Com a aprovação do Regimento Geral da UnB aprovado pelo Conselho Federal de Educação em 13 de março de 1970, homologado em 25 de abril de 1970 pelo Ministro da Educação e Cultura e publicado no Diário Oficial da União em 6 de maio de 1970, permitiu-se a criação da primeira Comissão Permanente de Concurso Vestibular (COPEVE/UnB).

Como a UnB havia estabelecido novo regime de ensino semestral a partir de 1971, iniciou-se a forma de seleção semestral e a UnB passou a realizar dois vestibulares por ano, com provas de múltipla escolha de quatro opções cada. A partir de 1974 introduziu-se peso diferente para cada matéria, de acordo com a opção de cada candidato. Em 1978 foi introduzida a prova de Redação em Língua Portuguesa, tendo sido realizada pela primeira vez a prova de Habilidade Específica para a pré-opção Música e depois para a pré-opção Educação Física, mantida até o $1 .^{\circ}$ Vestibular de 1980. A partir de então os vestibulares vêm sendo realizados precedidos de provas de habilitação específica.

Em 1987, a administração superior da UnB aprovou a criação da estrutura organizacional da Diretoria de Acesso ao Ensino Superior (DAE), passando a ser esta responsável pelo planejamento, coordenação, execução, controle e pesquisas das atividades de concursos vestibulares, bem como por buscar mecanismos similares e inovadores de acesso ao ensino de graduação e de outros concursos públicos.

Durante o período de funcionamento da DAE, consagrou-se o Sistema UnB de 
Avaliação, Classificação e Seleção, com base no Sistema de Vestibular UnB-80, a prova de redação passou a ser eliminatória, introduziu-se a prova de espanhol (em 1991), as provas objetivas foram revistas e as provas de habilidades específicas foram reprogramadas, foi introduzido o Boletim de Desempenho do candidato, reintroduzida a segunda chamada para aproveitamento das vagas não-ocupadas, interação do vestibular UnB com participação de professores do $2 .^{\circ}$ grau nos trabalhos de exame e críticas das provas, bem como a oferta de cursos de atualização para professores do ensino médio.

A partir da relativa autonomia administrativa, financeira e orçamentária, concedida à DAE pelo então Reitor, professor Cristóvão Buarque, esta intensificou suas atividades nos concursos públicos, eventos, congressos e conferências, o que permitiu a arrecadação de recursos e a melhoraria da infra-estrutura, tanto da DAE quanto das demais unidades administrativas da UnB, pois os recursos obtidos com a prestação dos serviços são destinados à atividade fim da Universidade.

Em novembro de 1993, com o crescimento das atividades da DAE, não mais compatível com sua estrutura administrativa, foi criado o CESPE, vinculado ao Gabinete do Reitor e com estrutura e base institucionais mais adequadas para os objetivos a que se propôs.

A partir de sua constituição, o CESPE/UnB tem implantado inovações, tais como: o boletim de desempenho das escolas (onde se avalia o desempenho das escolas com base no desempenho dos seus alunos); a sala dos professores (em que os professores do ensino médio fazem prova, simultaneamente, com os candidatos, gerando uma proposta de gabarito que é discutida pelas bancas examinadoras e repassada ao CESPE/UnB com observações e críticas); a mudança do horário de provas para o período vespertino (propiciou maior conforto para o candidato); o Guia do Vestibulando (melhor projeto gráfico e melhor nível de informação); descentralização das inscrições (informatização dos formulários e inscrição por meio da Internet); sistema de cotas para candidatos negros (foto digitalizada dos candidatos nos locais de inscrição para validação da inscrição); ingresso de candidato pelo Programa de Avaliação Seriada (PAS) - educação básica caracterizada como um processo contínuo de avaliação e seleção de alunos para a graduação, na qual o estudante é avaliado pela sua vida pregressa e a escola avaliada pelo seu ensino (programa esse com resultados positivos no aspecto metodológico, pedagógico e social).

Quando o CESPE/UnB começou a realizar concursos públicos, como conseqüência de sua experiência na aplicação de vestibulares, no início da década de noventa do século XX, foi necessário organizar estrutura em nível nacional, com representantes em todas as capitais e cidades de grande e médio porte do território nacional. Novamente se fez 
necessária a adequação interna e externa, a troca de equipamentos, treinamento de pessoal, redimensionamento do parque gráfico, e do quadro mínimo de pessoal do Centro.

No ano 2000 foi constituída a Gerência de Pesquisa em Avaliação, vinculada ao CESPE/UnB e cuja atuação tem se pautado pela avaliação do desempenho de alunos nos sistemas educacionais, tanto públicos como privados, nos concursos públicos, nos vestibulares. Esta gerência conta atualmente com um grupo de especialistas (psicometristas, estatísticos, pedagogos, matemáticos, lingüistas) que atua na área de avaliação de alunos inseridos nos sistemas educacionais e, mais recentemente, atuando em nível nacional com participação na avaliação do Exame Nacional do Ensino Médio (ENEM); no Exame Nacional de Desempenho dos Estudantes dos Cursos de Graduação (ENADE); no Exame Nacional para Certificação de Competências de Jovens e Adultos (ENCCEJA); ANEB, Banco do Brasil, SESI/SP, SENAI, Escolas Americanas, entre outros.

Em dezembro de 2005, o então Reitor Prof. Timothy Martin Mulholland aprovou a atual estrutura organizacional do CESPE/UnB, que compreende:

I Conselho Técnico-Consultivo;

II Diretoria-Geral:

a) Assessoria Técnica;

b) Secretaria Administrativa;

c) Ouvidoria.

III Diretoria-Executiva:

a) Centros Regionais;

b) Comitê Executor;

c) Comitê de Ética e Disciplina.

IV Central de Atendimento;

V Coordenadoria de Planejamento e Gestão:

a) Gerência de Operações Contábeis e Financeiras;

b) Gerência de Recursos Materiais e Patrimoniais;

c) Gerência de Recursos Humanos;

d) Gerência de Infra-estrutura e Manutenção.

VI Coordenadoria Acadêmica:

a) Gerência de Acesso à Educação Superior;

b) Gerência de Concursos Públicos;

c) Gerência de Diagramação e Impressão. 
VII Coordenadoria de Negócios:

a) Gerência de Atendimento a Clientes Institucionais;

b) Gerência de Contratos e Propostas;

c) Gerência de Educação Corporativa.

VIII Coordenadoria de Tecnologia:
a) Gerência de Controle e Conferência;
b) Gerência de Administração de Redes e Banco de Dados;
c) Gerência de Produção Digital;
d) Gerência de Desenvolvimento e Produção.

IX Coordenadoria de Logística de Eventos:
a) Gerência de Espaço Físico e Transportes;
b) Gerência de Distribuição de Pessoal;
c) Gerência de Organização de Material.

X Coordenadoria de Pesquisa em Avaliação:
a) Gerência de Interação Educacional;
b) Gerência de Análise de Dados;
c) Gerência de Produção de Relatórios. 


\subsection{Estrutura organizacional do CESPE/UnB.}

O Centro de Seleção e de Promoção de Eventos (CESPE/UnB) é um dos treze centros vinculados à Reitoria e que se reporta, diretamente, ao Reitor, no que tange a suas decisões e políticas: administrativa, orçamentária e financeira. Constituído em 1993, é o responsável pelos processos de seleção e de ingresso de estudantes na Universidade e pela realização de concursos públicos e processos de avaliação institucional.

Como o CESPE/UnB trabalha com prestação de serviços e com o ineditismo das questões aplicadas nos concursos públicos e vestibulares que realiza os seus produtos e serviços nunca são padronizados, não são exatamente iguais a outros produtos entregues, pois as exigências dos contratantes variam de caso para caso. Esse fato demanda diferentes tipos de tratamento para cada cliente e fazem com que a Coordenadoria Acadêmica, a Coordenadoria de Tecnologia e a Coordenadoria de Pesquisa em Avaliação sejam pontos nevrálgicos na estrutura do CESPE/UnB. Devido à grande complexidade, esses setores precisam ser monitorados constantemente, uma vez que qualquer falha pode levar à perda direta do cliente e ainda a perda de futuros clientes.

Com base no Ato da Reitoria n. ${ }^{\circ} 1.654 / 2005$, que dispõe sobre a reestruturação organizacional do Centro de Seleção e de Promoção de Eventos da Universidade de Brasília, chegou-se ao organograma apresentado na Figura 8:

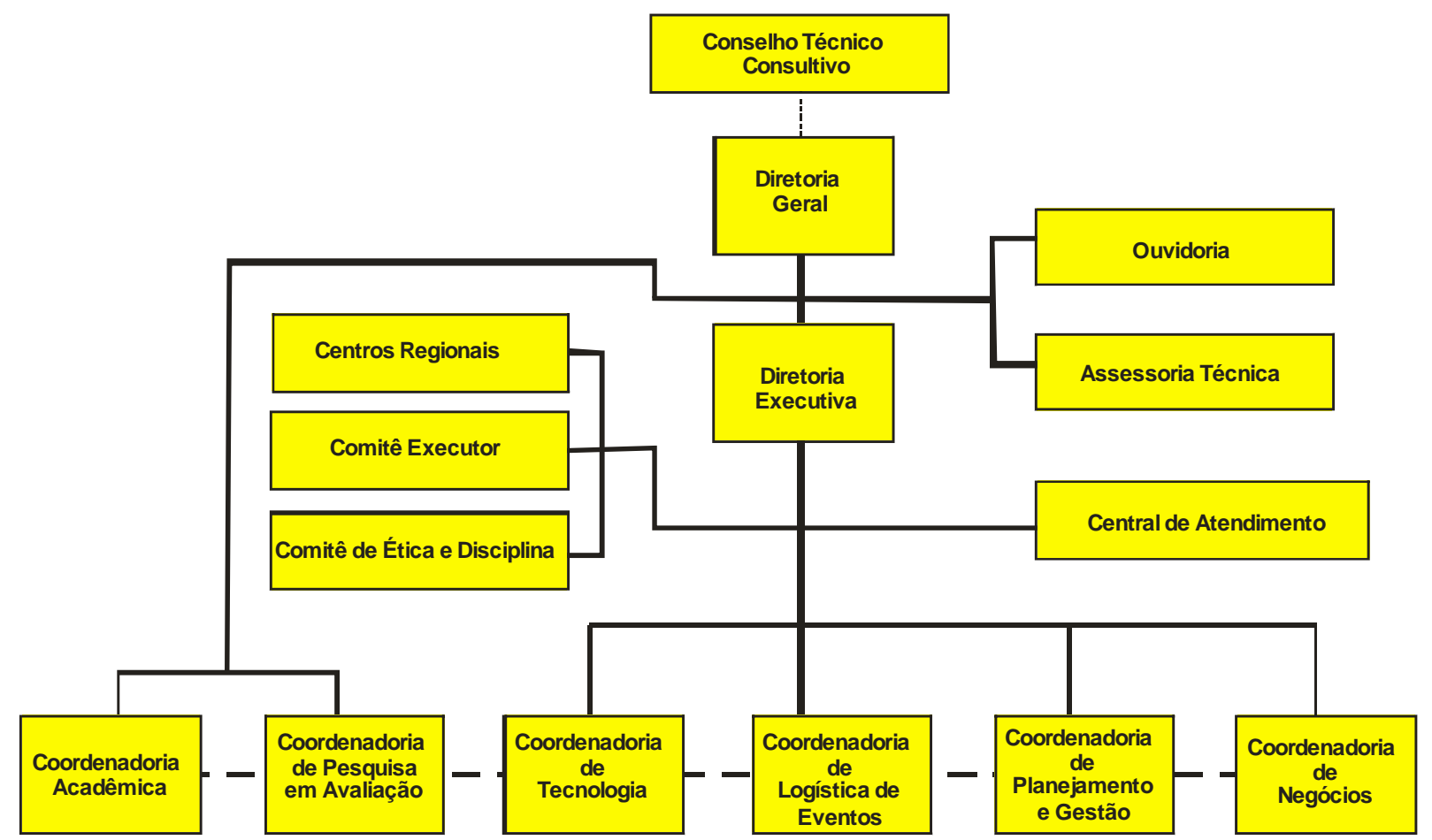

Figura 8 - Organograma do CESPE 


\subsection{Fluxo da contratação de concurso público no CESPE/UnB, com base no BSC.}

Tomando-se como base o BSC para uma das atividades do CESPE que seria a contratação de concurso, a primeira decisão a ser tomada seria a avaliação do fluxograma dessa atividade, de forma a enumerar todas as atividades existentes, suas entradas e saídas, para descobrir quais processos deveriam ser considerados como críticos e quais precisariam ser monitorados pelos Indicadores de Desempenho. A realização dessa fase resultará no fluxo apresentado na Figura 9.

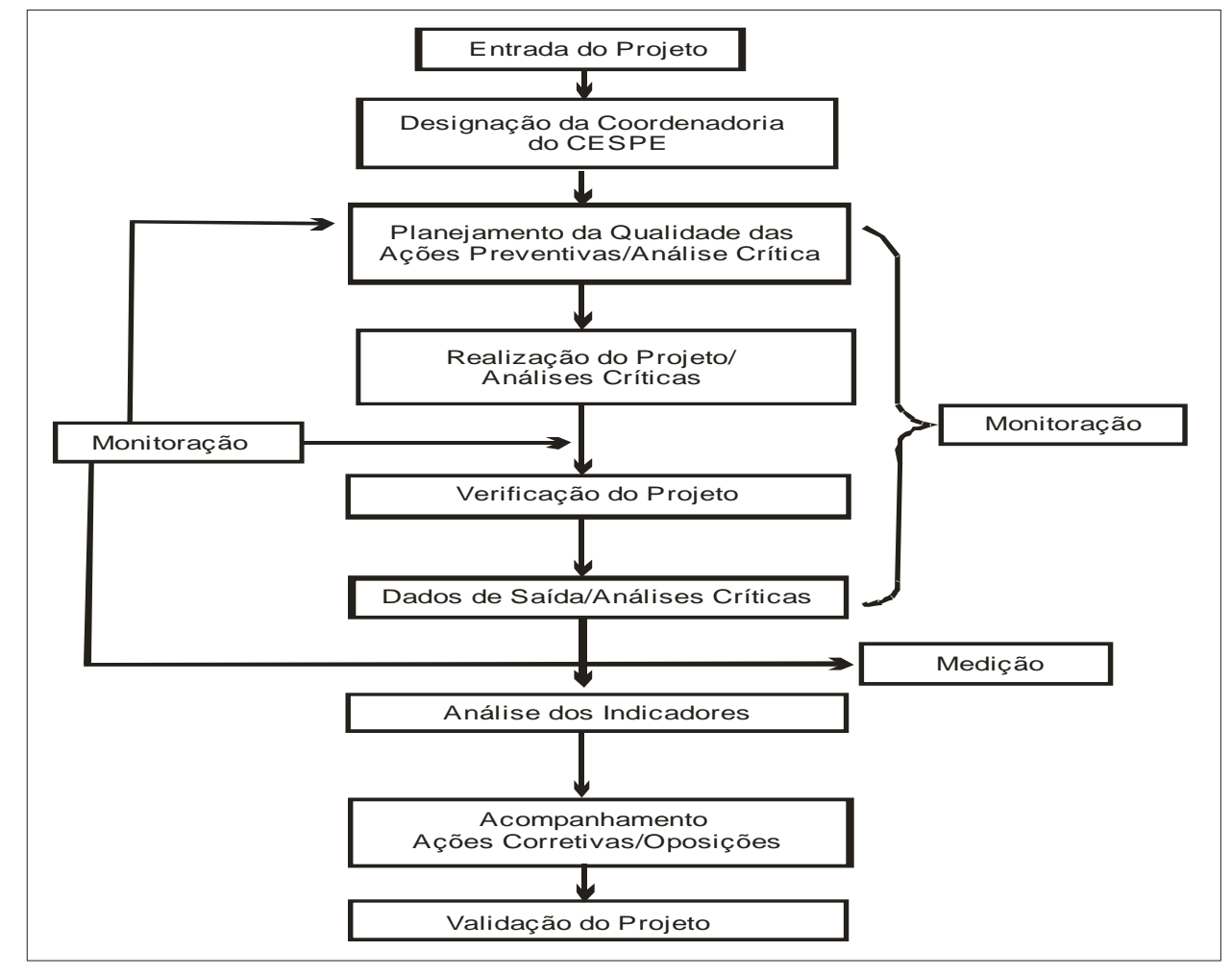

Figura 9 - Fases da execução dos projetos no CESPE/UnB

\subsection{Dados de Entrada de Projetos no CESPE/UnB}

Os dados de entrada do projeto serão identificados, determinados, documentados, analisados, criticados quanto a sua adequação e os requisitos incompletos e conflitantes, os que possuírem dupla interpretação deverão ser esclarecidos/resolvidos com as partes envolvidas. Deverão ser considerados, em primeiro lugar, os requisitos contratuais 
apresentados pelo cliente, inclusive requisitos estatutários e regras aplicáveis, resultantes da análise crítica de contrato e adendos contratuais negociados pela Coordenadoria de Negócios e referendados pela Direção Geral do CESPE/UnB.

Os dados de entrada seriam incluídos em um documento pertinente, como:

$\checkmark$ minuta do edital/contrato negociado;

$\checkmark$ orçamento negociado (quantidade de horas necessárias para a consecução do concurso, equipamentos necessários para atingir o objetivo do contrato, entre outros;)

$\checkmark$ proposta técnica consolidada;

$\checkmark$ requisitos estatutários, regulamentares, normatizantes, leis ambientais aplicáveis ao concurso, antes, durante e após fornecimento do produto.

$\checkmark$ súmula do concurso;

$\checkmark$ correspondências (cartas, fax, entre outros.)

\section{- Indicação dos responsáveis pelo evento/concurso}

Após o recebimento dos dados de entrada, seria designado um coordenador para o concurso ou evento. Este coordenador seria o responsável pela execução do projeto.

\section{- Planejamento da Qualidade / Ações Preventivas / Análise crítica}

Os eventos/concursos seriam planejados para assegurar que os prazos estabelecidos fossem cumpridos:

$\checkmark$ as horas vendidas não poderiam ser ultrapassadas;

$\checkmark$ o pessoal melhor qualificado seria empregado no evento/concurso;

$\checkmark$ os materiais e recursos necessários estariam disponíveis para a execução do evento/concurso;

$\checkmark$ assegurar-se-ía a conformidade dos requisitos do evento/concurso.

\section{- Análise Crítica de Projeto}

A análise crítica do evento/concurso teria como objetivo detectar, com antecedência, os problemas potenciais, as dificuldades de realização, além dos aspectos e impactos que porventura poderiam ocorrer, em função da realização do evento. Avaliar-se-ia a capacidade do atendimento das metas, em atender os pressupostos e requisitos, bem como identificar-se-íam os problemas e propor-se-íam as ações necessárias. A análise crítica deveria ser realizada nos momentos apropriados e definidas a cada evento/concurso, podendo ser realizado em várias fases como: elaboração de cálculos, elaboração das listas técnicas antes, 
durante ou após a execução do evento/concurso, definindo assim qual o melhor momento.

Os resultados das Análises Críticas do evento/concurso deveriam ser registrados de forma adequada como, por exemplo: em atas de reunião, check-list, e-mail e fax, entre outros. Deveriam ser mantidos registros dos resultados das verificações e de quaisquer ações necessárias.

\section{- Realização do Projeto}

Caberia à Coordenadoria de Negócios definir as responsabilidades e interfaces para elaborar, controlar, analisar, verificar, validar e controlar as alterações do projeto e o desenvolvimento do produto, a fim de assegurar o atendimento dos requisitos especificados.

\section{- Verificação do Projeto}

Em dado momento o projeto seria verificado para assegurar que a saída deste estágio atende aos seus requisitos de entrada do projeto e desenvolvimento. As medidas de verificação deveriam ser mantidas com registros dos resultados da verificação e de quaisquer ações necessárias.

\section{- Dados de Saída de Projeto}

Após a análise crítica dos dados de entrada, deveria proceder-se à elaboração dos seguintes documentos: Memórias de Cálculo, Lista de Transportes, Especificação Técnica de Consulta, Especificação Técnica de Proposta, Folha de Informação de Horas necessárias para consolidação do projeto, Resumo dos Requisitos para Controle, Registro de Riscos Técnicos.

Os documentos acima poderiam ser suprimidos ou outros documentos poderiam ser emitidos, de acordo com as necessidades de cada evento/concurso.

Os dados de saída do projeto deveriam estar atualizados e documentados de forma adequada na medida em que o projeto fosse se desenvolvendo e progredindo. Concomitantemente seriam feitas a verificação e a validação com relação aos requisitos de entrada do projeto.

As saídas do projeto de desenvolvimento deveriam:

$\checkmark$ atender aos requisitos de entrada para projeto e desenvolvimento;

$\checkmark$ fornecer informações apropriadas para aquisição, produção e desenvolvimento das tarefas de modo adequado;

$\checkmark$ conter ou referenciar critérios de aceitação do produto; e 
$\checkmark$ especificar as características e os meios essenciais e necessários para a consecução do evento/concurso;

\section{- Análise dos Indicadores de Desempenho}

A análise dos Indicadores de desempenho deveria ser feita periodicamente, conforme prazos estabelecidos pela alta direção ou conforme a necessidade de cada projeto. Este acompanhamento seria realizado com o objetivo de verificar o desempenho geral do concurso, bem como os resultados dos trabalhos realizados nos projetos. Quando fossem verificadas nos indicadores de desempenho alguma falha ou possibilidade de melhoria, seriam estabelecidas disposições e ações corretivas e preventivas (quando necessário).

Caso fosse detectada a possibilidade de ocorrência do não cumprimento de alguma atividade pré-estabelecida, seria feita a divulgação da divergência a todas as áreas afetadas. Dessa forma poderiam ser analisadas as possíveis consequiências e, se necessário, tomadas as providências para minimizar os efeitos, como a renegociação dos prazos e a busca de alternativas prováveis e possíveis.

\section{- Validação do Projeto}

O CESPE deverá validar o projeto para assegurar que o produto esteja em conformidade com as necessidades e/ou requisitos definidos pelo cliente. Quando for praticável, a validação deverá ser concluída antes da entrega do produto, e os resultados da validação seriam registrados, bem como qualquer ação necessária.

\section{- Modificações do Projeto}

As modificações do projeto deverão ser documentadas adequadamente, analisadas criticamente e aprovadas por pessoal autorizado, conforme designação de atribuições e responsabilidades pertinentes as diretorias, coordenadorias ou setores envolvidos na consecução dos fins.

Quando requerido contratualmente, as modificações do projeto deverão ser submetidas ao cliente, ou ao seu representante técnico, para conhecimento e/ou aprovação.

Após a definição das atividades do CESPE, deverá ser dado início à próxima atividade, ou seja, à identificação dos processos que necessitam ser monitorados pelos Indicadores de Desempenho.

Após a definição dessas atividades, dar-se-ia início ao próximo passo: a identificação das necessidades de monitoramento pelos indicadores de desempenho e o 
estabelecimento de quais serão estes indicadores de desempenho.

Kaplan e Norton (1997), afirmam que

Os sistemas de medida de desempenho da maioria das empresas focalizam a melhoria dos processos operacionais existentes. Para o Balanced Scorecard, recomendamos que os executivos definam uma cadeia de valor completa dos processos internos que tenha início com o processo de inovação - identificação das necessidades atuais e futuras dos clientes e desenvolvimento de novas soluções para essas necessidades (Kaplan e Norton, 1997, p.97)

Segundo Campos (2006), a rotina é a base de qualquer tipo de gerenciamento. É a rotina que permite a participação de todas as pessoas de uma organização de forma organizada e disciplinada. Não se pode falar em disseminação de melhores práticas se não se tem uma boa rotina. Ao se desejar dar um passo adiante e ter uma grande organização para o futuro, a rotina deverá ser um esforço constante, pois é a base de todo o resto. A padronização é a base do Gerenciamento da Rotina.

O exemplo do fluxo de concurso apresentado neste estudo visa demonstrar como ele está relacionado com a perspectiva cliente, citado por Kaplan e Norton e que, apesar de estar inserido no contexto dos processos internos e ser uma rotina de trabalho, precisa receber especial atenção, quando se trata da implantação do BSC. 


\section{APLICAÇÃO DO BSC À ADMINISTRAÇÃO PÚBLICA}

Kaplan e Norton (1997) asseveram que, na Administração Pública, o BSC potencializa a razão principal da sua existência (servir os clientes e não apenas controlar os gastos orçamentais) e permite a comunicação, aos empregados, dos resultados e dos indutores de atuação que permitirão alcançar os objetivos estratégicos. Para eles, o sucesso das organizações públicas deve ser medido pelo grau de eficiência e eficácia com que as organizações atendem às necessidades de seus participantes, com base na definição de objetivos tangíveis para os clientes e participantes.

Segundo os autores, é uma característica dos órgãos públicos terem maior responsabilidade perante a sociedade e os contribuintes. Nesse caso o BSC pode proporcionar às organizações públicas foco, motivação e responsabilidade significativos, pois a base dessas organizações é servir clientes e partes interessadas, manter gastos dentro dos limites orçamentários e comunicar externa e internamente os resultados e os vetores de desempenho pelos quais a organização realizará sua missão e alcançará seus objetivos estratégicos.

Diferentemente das empresas particulares, as instituições públicas, dentre as quais a Fundação Universidade de Brasília (FUB) se inclui, são predestinadas a prestar serviços à comunidade - cujo lucro não se expressa em termos financeiros, mas, sim em nível de satisfação da comunidade —, priorizam a perspectiva CLIENTE, conforme se pode observar na Figura 10, abaixo.

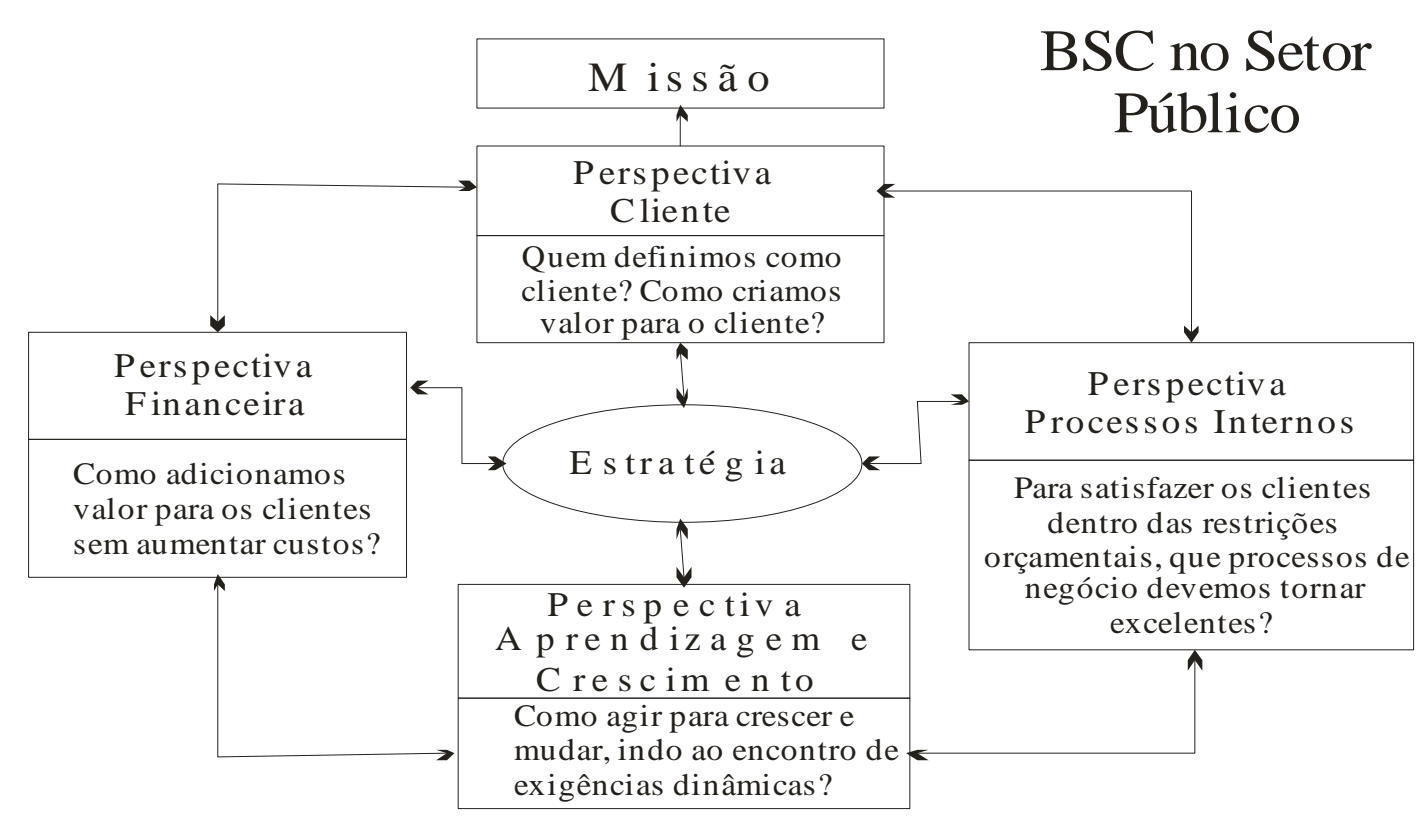

Figura 10 - Estrutura do BSC aplicado ao serviço público Fonte: Pedro, 2004, p.19. 
Segundo Pedro (2004), "como o BSC nasceu no meio empresarial e tem sido desenvolvido em torno dessa realidade, não o podemos aplicar sem adaptações à realidade do setor público". Para traduzir os processos em alto desempenho no serviço público, as empresas deverão, em primeiro lugar, satisfazer os clientes (usuários). Para se obter eficácia global, é necessário aplicar a metodologia em mais de um departamento. Ressalta também, que os gestores públicos, devido à complexidade dessa metodologia, devem analisar e responder a algumas perguntas:

$\checkmark$ Estamos a satisfazer os nossos clientes?

$\checkmark$ Os grupos de interesse (funcionários, gestão de topo, legisladores, fundadores e entidades de tutela do departamento em causa) estão satisfeitos e mostram estabilidade?

$\checkmark$ Está a acontecer alguma alteração com a base dos nossos clientes? A estratégia global adotada está a funcionar? As estratégias individuais estão alinhadas com a estratégia global?

$\checkmark$ Somos eficientes? Estamos a ser eficazes em termos de quantidade e qualidade do serviço?

$\checkmark$ Os grupos de interesse estão a contribuir com idéias construtivas?

$\checkmark$ Estamos a desenvolver as competências necessárias para executar as estratégias que definimos?

Com relação às perspectivas do $\mathrm{BSC}$, o autor revela algumas diferenças existentes entre o setor privado e o público, para a aplicação desta metodologia, conforme pode ser visto nas Figuras 11 até 15.

\section{Missão e estratégia}

\begin{tabular}{|l|l|}
\hline Sector Privado & Sector Público \\
\hline $\begin{array}{l}\text { A Estratégia fica no topo do } \\
\text { BSC. }\end{array}$ & A Estratégia fica no centro do BSC. \\
$\begin{array}{l}\text { A estratégia interfere com as } \\
\text { opções relativamente a } \\
\begin{array}{l}\text { Finanças, Clientes, Processos } \\
\text { Internos e Aprendizagem e } \\
\text { crescimento dos empregados. }\end{array}\end{array}$ & $\begin{array}{l}\text { com as opções relativamente a Finanças, Clientes } \\
\text { (cidadãos), Processos Internos e Aprendizagem e } \\
\text { crescimento dos funcionários. }\end{array}$ \\
\hline
\end{tabular}

Figura 11 - Diferenças da Missão e da estratégia no setor público e no privado Fonte: Pedro, 2004, p.46. 


\section{Perspectiva Financeira}

\begin{tabular}{|c|c|}
\hline Sector Privado & Sector Público \\
\hline $\begin{array}{l}\text { Trata das necessidades de } \\
\text { satisfação dos accionistas } \\
\text { (criação de valor sustentável) } \\
\text { e dos clientes e de geração de } \\
\text { cash-flow. }\end{array}$ & $\begin{array}{l}\text { Os indicadores financeiros em organizações não } \\
\text { lucrativas podem ser vistos como catalizadores do } \\
\text { sucesso dos clientes (cidadãos) ou como } \\
\text { restrições entre as quais a organização deve } \\
\text { operar. }\end{array}$ \\
\hline $\begin{array}{l}\text { A utilização isolada de } \\
\text { indicadores financeiros faz } \\
\text { centrar as atenções da gestão } \\
\text { em resultados de curto prazo } \\
\text { que podem prejudicar a } \\
\text { criação de valor a longo prazo }\end{array}$ & $\begin{array}{l}\text { Será difícil colocar um preço justo ao trabalho que } \\
\text { executam (ex: acçōes de apoio à prevenção da } \\
\text { saúde). } \\
\text { As estratégias de aumento da receita não vêm do } \\
\text { aumento do valor oferecido ao cliente se o } \\
\text { financiamento não for indexado à satisfação dos } \\
\text { cidadãos e empresas (clientes) e da entidade que } \\
\text { tutela o serviço (accionistas). }\end{array}$ \\
\hline
\end{tabular}

Figura 12 - Diferenças da perspectiva financeira no setor público e no privado Fonte: Pedro, 2004, p.47.

\section{Perspectiva Clientes}

Sector Privado
Avalia a nossa actuação
relativamente à principal fonte
de receita da empresa.
Para obter resultados
financeiros é preciso oferecer
valor aos clientes e para saber
se estamos de facto a
caminhar nesse sentido é
indispensável medir.

\section{Sector Público}

A perspectiva Cliente sobe de nivel, relativamente ao BSC aplicado a empresas privadas.

A perspectiva cliente emerge da Missão e não da captação de recursos financeiros a partir dos interessados na empresa.

A organização deve determinar a quem serve e qual a melhor forma de o fazer para concretizar a sua missão.

Figura 13 - Diferenças da perspectiva clientes no setor público e no privado Fonte: Pedro, 2004, p.47.

\section{Perspectiva Processos Internos}

\begin{tabular}{|l|l|}
\hline Sector Privado & Sector Público \\
\hline $\begin{array}{l}\text { Para oferecer valor aos } \\
\text { clientes é necessário } \\
\text { processos internos } \\
\text { optimizados que permitam } \\
\text { obter niveis de custos baixos } \\
\text { e competitivos. }\end{array}$ & $\begin{array}{l}\text { Identificar processos internos que direccionam } \\
\text { valor para o cliente. } \\
\text { Que processos internos devemos melhorar até à } \\
\text { clientes (cidadãos e empresas)? }\end{array}$ \\
$\begin{array}{l}\text { Para isso é necessário gerire } \\
\text { medir sistematicamente os } \\
\text { nossos processos. }\end{array}$ & $\begin{array}{l}\text { Os processos escolhidos derivam normalmente } \\
\text { dos objectivos e indicadores escolnidos na } \\
\text { perspectiva cliente (ex: se queremos actuar sobre } \\
\text { o tempo de registo de uma empresa, devemos } \\
\text { actuar sobre as actividades que constituem esse } \\
\text { processo) }\end{array}$ \\
\hline
\end{tabular}

Figura 14 - Diferenças da perspectiva processos internos no setor público e no privado Fonte: Pedro, 2004, p.48. 


\section{Perspectiva Aprendizagem e Crescimento}

\begin{tabular}{|c|c|}
\hline Sector Privado & Sector Público \\
\hline $\begin{array}{l}\text { O êxito do desempenho dos } \\
\text { processos depende da } \\
\text { capacidade de construir, } \\
\text { manter e desenvolver as infra- } \\
\text { estruturas básicas da } \\
\text { organização (pessoas, } \\
\text { tecnologia, alianças, marcas, } \\
\text { organização,... } \\
\text { Para saber onde estamos é } \\
\text { necessário medir } \\
\text { sistematicamente e comparar }\end{array}$ & $\begin{array}{l}\text { O sucesso em aperfeiçoar processos, depende } \\
\text { em grande parte da habilidade dos funcionários e } \\
\text { das ferramentas que usam como suporte da sua } \\
\text { actividade. } \\
\text { Funcionários motivados com competências e } \\
\text { ferramentas adequadas operando num clima } \\
\text { organizacional desenhado para sustentar os } \\
\text { aperfeiçoamentos adoptados nos processos, são } \\
\text { os ingredientes centrais para prosseguir } \\
\text { melhorando continuamente, dentro dos limites } \\
\text { financeiros, em direcçäo ao sucesso dos clientes } \\
\text { (cidadãos) e realização da missão; }\end{array}$ \\
\hline
\end{tabular}

Figura 15 - Diferenças da perspectiva aprendizagem e crescimento nos setores público e privado Fonte: Pedro, 2004, p.48. 


\section{Aplicação do Balanced Scorecard às Empresas}

Soares Jr. e Prochnik (2004) realizaram uma pesquisa com a finalidade de identificar dificuldades e ganhos observados em onze grandes organizações que adotaram o BSC ou estão implantando esta ferramenta no Brasil. Segundo eles, Kaplan e Norton identificaram três tipos de problemas no desenvolvimento de organizações focalizadas na estratégia:

- Questões de transição - após processo de fusões e aquisições, envolvendo mudanças de controle e mudanças de liderança, as organizações, por vezes, retrocedem aos sistemas gerenciais tradicionais, por iniciativa dos novos gestores.

- Questões de projeto - deficiências de projeto associadas à adoção de poucos ou muitos indicadores sem o devido equilíbrio entre eles. Nesses casos, os scorecards dessas organizações não refletem a história da estratégia.

- Questões de processo - deficiências nos processos organizacionais devido a: a) falta de comprometimento da alta administração; b) envolvimento de muito poucas pessoas; encastelamento do scorecard no topo; c) processos de desenvolvimento muito longos;

d) tratamento do BSC como projeto de área de sistemas; e) contratação de consultores inexperientes; implementação do BSC apenas para fins de remuneração.

Metodologicamente a pesquisa se desenvolveu com base nas hipóteses mais relevantes apontadas por Kaplan e Norton, para o sucesso do BSC, comparando as experiências de implantação no Brasil com as recomendações dos próprios autores. Os levantamentos procuraram identificar se os processos de implantação no Brasil estavam indo na direção do que os autores do BSC denominaram de os cinco princípios da organização focalizada na estratégia, citadas anteriormente nas perspectivas do BSC. Com a finalidade de situar o leitor, repetiremos novamente:

1) a liderança como princípio das organizações focalizadas na estratégia;

2) a necessidade e as dificuldades associadas à tarefa de inserir a estratégia no centro do processo gerencial, ou seja, como traduzir a estratégia em termos operacionais. Isso é, a descrição da estratégia e do processo de criação de valor para os clientes através dos mapas estratégicos e balanced scorecards;

3) como o BSC está sendo utilizado para promover o alinhamento da organização para criar sinergias;

4) a utilização do BSC em diferentes processos para alinhar os funcionários com a 
estratégia, ou seja, assegurar sua execução, transformando a estratégia em tarefa cotidiana de todos;

5) a necessidade de implementação de um processo de gerenciamento da estratégia, ou seja, a transformação da estratégia em processo contínuo.

Além destes cinco princípios, foram analisados os seguintes:

6) as motivações ou objetivos do projeto BSC nas empresas analisadas;

7) os benefícios esperados e/ou proporcionados, para a organização, até o momento, em decorrência da utilização do BSC;

8) as lições aprendidas até o momento com esse projeto;

9) os problemas no desenvolvimento de organizações focalizadas na estratégia, identificados, pelos autores, como: questões de transição, de projeto, e de processo;

10) os ganhos do compartilhamento de informações e alinhamento dos funcionários com a estratégia vis-à-vis os riscos da explicitação da estratégia;

11) a pressão por resultados no curto prazo vis-à-vis a busca do equilíbrio entre diferentes perspectivas e aspectos presentes no BSC;

12) a existência de possíveis peculiaridades da realidade brasileira e os potenciais desdobramentos nos projetos de BSC.

Das onze empresas, duas, a Siemens e a Oxiteno, foram analisadas por meio de questionário detalhado. As nove restantes apresentaram seus resultados durante o I Fórum Balanced Scorecard Brasil, realizado em agosto de 2002, na cidade de São Paulo. É necessário observar que duas empresas, o Banco do Brasil e a Eletrosul são empresas do Governo Federal. Os resultados encontram-se nos Quadros 2 e 3: 


\begin{tabular}{|c|c|c|}
\hline Aspectos/ Organizações & SIEMENS & $\begin{array}{c}\text { OXITEN } \\
\text { O }\end{array}$ \\
\hline $\begin{array}{l}\text { 1-Identificação de benefícios do BSC: } \\
\text { 1.1-Mensuração de desempenho da organização } \\
\text { 1.2-Implementação de estratégias } \\
\text { 1.3-Modelo de gestão estratégica } \\
\text { 1.4-Resultados econômico-financeiros do projeto }\end{array}$ & $\begin{array}{l}X \\
X \\
X \\
\end{array}$ & $\begin{array}{l}X \\
X \\
X\end{array}$ \\
\hline $\begin{array}{lrllll}\text { 2-Envolvimento da } & \text { equipe } & \text { executiva } & \text { no } & \text { processo } & \text { de } \\
\text { implantação do BSC } & & & & & \\
\end{array}$ & $\mathrm{X}$ & $\bar{X}$ \\
\hline $\begin{array}{l}\text { 3-Busca de equilíbrio entre indicadores financeiros e não } \\
\text { financeiros }\end{array}$ & $\bar{X}$ & $\bar{X}$ \\
\hline 4-Utilização de Mapas Estratégicos & $\mathrm{X}$ & $\mathrm{X}$ \\
\hline $\begin{array}{l}\text { 5-Obtenção de sinergias entre unidades, áreas e setores } \\
\text { através do BSC }\end{array}$ & $\mathrm{I}$ & \\
\hline $\begin{array}{l}\text { 6-Intenção de desdobrar os Mapas Estratégicos e BSC à } \\
\text { nível de áreas, equipes e pessoas }\end{array}$ & $\mathrm{X}$ & $\mathrm{X}$ \\
\hline $\begin{array}{l}\text { 7-Participação dos níveis intermediários nas discussões } \\
\text { sobre o BSC }\end{array}$ & $\bar{x}$ & $\bar{X}$ \\
\hline $\begin{array}{l}\text { 8-Uso de recursos de comunicação para divulgação do } \\
\text { projeto BSC }\end{array}$ & $\mathrm{X}$ & $\mathrm{X}$ \\
\hline $\begin{array}{lcccc}\text { 9-Utilização de treinamento dos } & \text { funcionários } & \text { para a } \\
\text { participação no projeto BSC } & & & & \\
\end{array}$ & $\mathrm{X}$ & $\mathrm{X}$ \\
\hline $\begin{array}{l}\text { 10-Vinculação dos sistemas de incentivos e recompensas da } \\
\text { organização ao BSC }\end{array}$ & $\mathrm{I}$ & \\
\hline 11-Ligação do planejamento estratégico com o BSC & $\mathrm{X}$ & $\mathrm{X}$ \\
\hline 12-Ligacão do orçamento anual com o BSC & $\mathrm{I}$ & I \\
\hline 13-Utilização de solução de tecnologia da informação & $\mathrm{X}$ & $\mathrm{I}$ \\
\hline $\begin{array}{lllll}\begin{array}{l}\text { 14-Utilização de planilhas eletrônicas e softwares de } \\
\text { apresentação }\end{array} & & & \\
\end{array}$ & $\mathrm{X}$ & $\mathrm{X}$ \\
\hline 15-Utilização de consultoria externa & $\bar{X}$ & $\bar{X}$ \\
\hline $\begin{array}{l}\text { 16-Ampliação da divulgação de informações estratégicas da } \\
\text { organização com o BSC }\end{array}$ & $\mathrm{X}$ & $\mathrm{X}$ \\
\hline
\end{tabular}

Legendas: $\mathrm{X} \rightarrow$ presente no processo; $\mathrm{NI} \rightarrow$ não identificado na fonte de pesquisa; $1 \rightarrow$ presente no processo de forma incipiente ou como intenção.

Fonte: entrevistas realizadas em outubro de 2002.

\section{Quadro 2 - Resultados da implantação do BSC na SIEMENS e OXITENO}

Fonte: Soares Jr. e Prochnik, 2004, p.9 


\begin{tabular}{|c|c|c|c|c|c|c|c|c|c|}
\hline ASPECTOS / ORGANIZAÇÕES & \begin{tabular}{|c|}
$A$ \\
$R$ \\
$A$ \\
$C$ \\
$R$ \\
UZ \\
\end{tabular} & \begin{tabular}{|l} 
BAN \\
CO \\
DO \\
BRA \\
SIL
\end{tabular} & \begin{tabular}{|l|} 
CIA \\
SU \\
ZA \\
NO
\end{tabular} & $\begin{array}{c}\text { E } \\
\text { LE } \\
\text { TR } \\
\text { O } \\
\text { SUL }\end{array}$ & $\begin{array}{c}\text { GRU } \\
\text { PO } \\
\text { GER } \\
\text { DAU }\end{array}$ & \begin{tabular}{|c} 
IN \\
TE \\
R \\
CH \\
AN \\
GE
\end{tabular} & \begin{tabular}{|c} 
PE \\
TR \\
O \\
BR \\
Á \\
S
\end{tabular} & $\begin{array}{l}\mathrm{SE} \\
\mathrm{NAI}\end{array}$ & $\begin{array}{c}\text { UNl } \\
\text { BA } \\
\mathrm{N} \\
\mathrm{CO}\end{array}$ \\
\hline $\begin{array}{l}\text { 1- Identificação de benefícios do BSC: } \\
\text { 1.1- Mensuração do desempenho da } \\
\text { organização } \\
\text { 1.2- Implementação de estratégias } \\
\text { 1.3- Modelo de gestão estratégica } \\
\text { 1.4- Resultados econômico-financeiros } \\
\text { do projeto }\end{array}$ & $\begin{array}{l}x \\
X \\
X\end{array}$ & $\begin{array}{l}X \\
X\end{array}$ & $\begin{array}{l}X \\
X \\
X\end{array}$ & $\begin{array}{l}X \\
X \\
X\end{array}$ & $\mathrm{x}$ & $\begin{array}{l}X \\
X \\
X\end{array}$ & $\begin{array}{l}X \\
X \\
X\end{array}$ & $\begin{array}{l}X \\
X \\
x\end{array}$ & $\begin{array}{l}X \\
X \\
X\end{array}$ \\
\hline $\begin{array}{l}\text { 2- Envolvimento da equipe executiva no } \\
\text { processo de implantação do BSC }\end{array}$ & $\mathrm{x}$ & $\mathrm{x}$ & $\mathrm{x}$ & $\mathrm{x}$ & $\mathrm{x}$ & $\mathrm{x}$ & $\mathrm{x}$ & $\mathrm{x}$ & $\mathrm{x}$ \\
\hline $\begin{array}{l}\text { 3- Busca de equilíbrio entre indicadores } \\
\text { financeiros e não financeiros }\end{array}$ & $\mathrm{x}$ & $\mathrm{X}$ & $\mathrm{X}$ & $\mathrm{x}$ & $\mathrm{x}$ & $x$ & $\mathrm{X}$ & $\mathrm{x}$ & $\mathrm{x}$ \\
\hline $\begin{array}{l}\text { 4- Uso de mapas estratégicos } \\
\text { 5- Obtenção de sinergias entre } \\
\text { unidades, áreas, setores, fornecedores } \\
\text { e parceiros via BSC }\end{array}$ & $\mathrm{X}$ & $\mathrm{X}$ & $\mathrm{X}$ & $\mathrm{X}$ & $\mathrm{X}$ & $\mathrm{X}$ & $\mathrm{X}$ & $\mathrm{X}$ & $\mathrm{X}$ \\
\hline $\begin{array}{l}\text { 6- Intenção de desdobrar os mapas } \\
\text { estrateg. e BSC à nível de áreas, } \\
\text { equipes e pessoas }\end{array}$ & $\mathrm{x}$ & $\mathrm{x}$ & $\mathrm{x}$ & $\mathrm{X}$ & $\mathrm{x}$ & $\mathrm{x}$ & $\mathrm{X}$ & $\mathrm{X}$ & $\mathrm{X}$ \\
\hline $\begin{array}{l}\text { 7- Participação dos níveis intermediários } \\
\text { nas discussões em torno do BSC }\end{array}$ & $\mathrm{X}$ & $\mathrm{X}$ & $\mathrm{x}$ & $\mathrm{x}$ & $\mathrm{x}$ & $\mathrm{x}$ & $\mathrm{x}$ & $\mathrm{x}$ & $\mathrm{x}$ \\
\hline $\begin{array}{l}\text { 8- Uso de recursos de comunicação } \\
\text { para a divulgação do projeto BSC }\end{array}$ & $\mathrm{X}$ & $\mathrm{X}$ & $\mathrm{X}$ & $\mathrm{X}$ & $\mathrm{X}$ & $\mathrm{X}$ & $\mathrm{X}$ & $\mathrm{x}$ & $\mathrm{X}$ \\
\hline $\begin{array}{l}\text { 9- Uso de treinamento dos funcionários } \\
\text { para a participação no projeto BSC }\end{array}$ & $\mathrm{x}$ & $\mathrm{X}$ & $\mathrm{x}$ & $\mathrm{x}$ & $\mathrm{x}$ & $\mathrm{X}$ & $\mathrm{X}$ & $\mathrm{x}$ & $\mathrm{X}$ \\
\hline $\begin{array}{lll}10-\text { Vinculação } & \text { dos sistemas } & \text { de } \\
\text { incentivos e } & \text { recompensas } & \text { da } \\
\text { organização ao BSC } & & \\
\end{array}$ & & & & & & & & & \\
\hline 11 Ligação do planej. Estrat. com o BSC & $\mathrm{X}$ & $\mathrm{X}$ & $\mathrm{x}$ & $\mathrm{X}$ & $\mathrm{X}$ & $\mathrm{X}$ & $\mathrm{X}$ & $\mathrm{X}$ & $\mathrm{X}$ \\
\hline 12- Ligação do orçamento com o BSC & 1 & $\mathrm{I}$ & 1 & $\mathrm{I}$ & 1 & $\mathrm{I}$ & $\mathrm{I}$ & $\mathrm{I}$ & 1 \\
\hline $\begin{array}{l}\text { 13- Utilização de solução de tecnologia } \\
\text { da informação }\end{array}$ & $\mathrm{I}$ & $\mathrm{I}$ & $\mathrm{I}$ & $\mathrm{x}$ & $\mathrm{I}$ & $\mathrm{I}$ & $\mathrm{x}$ & $\mathrm{x}$ & $\mathrm{x}$ \\
\hline $\begin{array}{l}\text { 14- Utilização de planilhas eletrônicas e } \\
\text { softwares de apresentação }\end{array}$ & $\mathrm{NI}$ & $\mathrm{X}$ & $\mathrm{NI}$ & $\mathrm{NI}$ & $\mathrm{x}$ & $\mathrm{NI}$ & $\mathrm{NI}$ & $\mathrm{NI}$ & $\mathrm{NI}$ \\
\hline 15- Recurso a consultoria externa & $\mathrm{X}$ & $\mathrm{X}$ & $\mathrm{X}$ & $\mathrm{X}$ & $\mathrm{X}$ & $\mathrm{X}$ & $\mathrm{X}$ & $\mathrm{X}$ & $X$ \\
\hline $\begin{array}{lll}16- & \text { Ampliação da divulgação } & \text { de } \\
\text { informações } & \text { estratégicas } & \text { da } \\
\text { organização com o BSC } & \\
\end{array}$ & $\mathrm{x}$ & $x$ & $x$ & $X$ & $X$ & $X$ & $x$ & $x$ & $X$ \\
\hline
\end{tabular}

Legenda: $\mathrm{X} \rightarrow$ presente no processo; $\mathrm{NI} \rightarrow$ não identificado na fonte de pesquisa; I $\rightarrow$ presente no processo de forma incipiente ou como intenção.

Fonte: palestras apresentadas durante o evento / Fórum Balanced Scorecard Brasil, em São Paulo, em agosto/2002 e BSC Exhibition, em Belo Horizonte, em 11/10/2002.

\section{Quadro 3 - Resultado comparativo da implantação do BSC em nove organizações Fonte: Soares Jr. e Prochnik, 2004, p.10}

Todos os casos analisados pelos autores apontaram para um papel de relevante importância dos principais executivos para o sucesso do projeto BSC que é um dos princípios da organização voltada para a estratégia, de acordo com Kaplan e Norton. Com relação às 
quatro perspectivas do BSC (finanças, clientes, processos internos, aprendizado e crescimento) foi constatado estarem presentes em todos os casos, com acréscimos ou não, de perspectivas específicas, em função da necessidade de cada empresa em particular.

A participação de consultores externos no projeto foi vista de forma positiva pelas empresas, uma vez que se podem trazer experiências de outras organizações e facilitar as discussões de propostas e pontos de vista viciados, bem como para que as equipes de trabalho possam separar o que é operacional do que é estratégico, pois há muita confusão neste nível de discussão.

Quanto aos objetivos, percebeu-se que quanto maior a seletividade e concentração no que é relevante para a consecução dos fins, melhor serão os resultados alcançados e menos confusos ficarão os mapas estratégicos.

Outra conclusão é a de que os indicadores devem ser claramente definidos e bem articulados ao projeto, evitando-se trocar indicadores em curto espaço de tempo. É preciso que se tenha certeza de sua adequação ou não ao projeto. Sugeriu-se um tempo mínimo para troca de indicador em torno de um ciclo anual de revisão do BSC.

Soares Jr. e Prochnik (2004) concluíram que a metodologia do BSC pode ser um bom instrumento de negociação de desempenho para com as equipes de trabalho, pois esta metodologia tem se revelado bastante flexível e ajustável às diferentes circunstâncias.

A capacitação dos funcionários nos conceitos e na metodologia do BSC e o apoio de uma consultoria especializada constituem-se num dos primeiros passos para implantação do projeto BSC.

A comunicação deve ser aberta, transparente e dirigida, com a finalidade de construir a consciência estratégica em todos os níveis. Deve-se divulgar e proporcionar uma discussão das informações estratégicas, tanto pela comunicação tradicional, como pela utilização dos recursos tecnológicos, como a Intranet.

Em relação à realidade brasileira foi observado que a nossa cultura pode fazer com que vejamos o processo como mais uma burocracia, podendo ser um entrave à disciplina necessária e à implantação do BSC, principalmente no que se refere às rotinas dos sistemas informatizados. Como o brasileiro é uma pessoa aberta às novidades isso pode facilitar a disseminação do projeto BSC.

No quesito econômico, a variação da taxa de câmbio e a instabilidade econômica dificultam o processo de estabelecimento dos objetivos, metas e iniciativas de longo prazo. Isto é visto como um obstáculo para que os gerentes e executivos estabeleçam compromissos de médio e longo prazo. Soares Jr. e Prochnik (2004) acham que o BSC vem 
justamente contribuir com esse aspecto, porque o instrumento pode desenvolver a capacidade de antecipação da empresa a diversas situações, propiciando um ambiente que discute as alternativas de ação e reação.

Com relação ao uso de softwares específicos para o desenvolvimento dos projetos, algumas empresas optaram pela compra quando de sua implantação, outras, deixaram para adquiri-los no momento em que o projeto viesse a precisar de apoio para o crescimento. Os recursos de tecnologia mais citados foram o MS Excel, MS Power Point, além dos sistemas ERP, CRM e BI.

Quanto aos benefícios nos casos estudados, houve uma convergência para a opinião de que a metodologia traz uma clareza no sentido de permitir que as pessoas priorizem o que deve ser priorizado, ou seja, o alinhamento e direção em que todas as forças são direcionadas para competir lá fora e não dentro da organização. Maior transparência, próatividade, alinhamento e relacionamento. As organizações deram preferência por associar ganhos qualitativos ao projeto BSC. 


\section{METODOLOGIA}

\subsection{Tipo de Pesquisa}

As pesquisas são classificadas, segundo Vergara (2006), em dois aspectos: quanto aos fins e quanto aos meios. No primeiro caso, quanto aos fins, "a pesquisa será exploratória e descritiva" No segundo caso, quanto aos meios, "a pesquisa será bibliográfica, documental e de campo".

No presente caso, a pesquisa realizada foi exploratória e descritiva, porque em que pese à notoriedade do CESPE, não se verificou a existência de estudos que abordem a viabilidade da aplicação do "Balanced Scorecard" na instituição. Descritiva "enquanto procurou descrever percepções, expectativas e sugestões do pessoal técnico-administrativo e de nível superior...”. Bibliográfica, porque na fundamentação teórica da monografia foram analisados autores já consagrados no tema "Balanced Scorecard", publicados em material científico, livros, revistas e meios eletrônicos que dispõem sobre o assunto.

\subsection{Participantes da pesquisa}

A pesquisa deveria ser feita inicialmente com todos os funcionários do CESPE. Como isto não foi possível foram selecionados alguns setores, para os quais foi fornecido um questionário para preenchimento, com questões do tipo fechadas, cujo questionário encontrase em anexo ao trabalho. Com relação às entrevistas, foi entrevistado um dos diretores do CESPE.

Após o recolhimento dos questionários, procedeu-se à preparação dos dados para análise e tratamento. Em seguida todos os questionários recolhidos foram numerados seqüiencialmente. Para a análise dos dados foi utilizada a ferramenta de cálculo SPSS. Utilizou-se para tal, entre outros, o método descritivo, teste de variação da homogeneidade da variância e a análise da variância One-WayAnova. 


\subsection{Instrumento}

O levantamento da situação vigente e dos possíveis pontos de estrangulamento foi realizado por meio de entrevistas e questionários dirigidos aos gestores, gerentes e aos servidores com percepção crítica de procedimentos, rotinas de trabalho e logística no âmbito da unidade.

A elaboração dos questionários e das entrevistas foi concebida com base na estrutura básica oferecida por Günther (1996): a) identificação do pesquisador e legitimação dos objetivos de pesquisa e b) uma estrutura lógica das temáticas apresentadas na coleta de dados. Os formulários do questionário e da entrevista encontram-se nos anexos deste trabalho.

\subsection{Roteiro de Entrevista}

Para a definição deste item traz-se à luz a assertiva de Ludke, (1986, p.33) que considera a entrevista como "uma das principais técnicas de trabalho em quase todos os tipos de pesquisa utilizados nas ciências sociais". O mesmo autor classifica as entrevistas como: a) estruturadas ou padronizadas, b) não-estruturada ou não padronizada e c) semi-estruturada. Considerando que a entrevista semi-estruturada ocorre a partir de um esquema básico, porém não aplicado com rigor, permitindo ao entrevistador introduzir as adaptações que julgar conveniente, entende-se que esta modalidade vem ao encontro da necessidade da pesquisa.

\subsection{Procedimentos}

As informações obtidas da aplicação dos questionários foram tratadas de forma estatística e compuseram as tabelas para subsídio da análise dos dados. Os dados obtidos nas entrevistas e nos questionários foram organizados e consolidados em tabelas de modo a permitir o acesso fácil às conclusões. Um dos diretores do CESPE foi entrevistado e os dados coletados, analisados, discutidos, tabulados e descritos na conclusão. 


\section{RESULTADOS}

\subsection{Definição e caracterização da população}

No presente estudo considerou-se fundamental conhecer a opinião de docentes, funcionários e prestadores de serviço no âmbito do CESPE. Para tanto, elaborou-se um instrumento denominado questionário, onde os respondentes, de forma individualizada, colocaram sua opinião sobre assuntos como conhecimento do plano estratégico no âmbito da FUB e do CESPE, missão, visão, importância de se ter mecanismos para avaliar a evolução da estratégia.

Inicialmente pensou-se em aplicar o questionário a todo o corpo funcional do CESPE, e para tanto foi enviado o referido instrumento por meio eletrônico para o corpo técnico e docente, totalizando 230 dos quais se obteve apenas 45 respondidos.

Portanto, o tamanho da amostra foi de 45 respondentes, divididos pelas categorias de professor, prestador de serviços em nível administrativo, assistentes de administração, técnicos de nível médio, superior e de informática. Dos participantes, dois possuem segundo grau incompleto, quinze possuem segundo grau completo, dezessete possuem graduação, seis possuem mestrado e cinco possuem doutorado, conforme Tabela 1 abaixo:

Tabela 1 - Habilitação acadêmica dos respondentes, por categoria profissional

\begin{tabular}{l|c|c|c|c}
\hline Escolaridade & Freqüência & Percentual & $\begin{array}{c}\text { Percentual } \\
\text { válido }\end{array}$ & $\begin{array}{c}\text { Percentual } \\
\text { Acumulado }\end{array}$ \\
\hline $2^{\circ}$ completo & 15 & 33,3 & 33,3 & 33,3 \\
$2^{\circ}$ incompleto & 2 & 4,4 & 4,4 & 37,8 \\
Graduação & 17 & 37,8 & 37,8 & 75,6 \\
Mestrado & 6 & 13,3 & 13,3 & 88,9 \\
Doutorado & 5 & 11,1 & 11,1 & 100,0 \\
Total & 45 & 100,0 & 100,0 & \\
\hline
\end{tabular}

Fonte: Dados da pesquisa

\subsection{Desenvolvimento e aplicação dos questionários e da entrevista}

Assim, o instrumento pretendeu avaliar o envolvimento dos docentes, funcionários e prestadores de serviço na gestão estratégica do CESPE, de forma a permitir a definição dos indicadores a serem utilizados no BSC, no caso de ser aceita esta metodologia.

Partindo-se do pressuposto de que uma grande parte da população não estava 
familiarizada com alguns conceitos relacionados ao tema em estudo, procurou-se elaborar um questionário de resposta simples. Para facilitar o entendimento, alguns conceitos de indicadores de avaliação foram explicitados entre parênteses. Dessa forma, optou-se por elaborar questões que permitissem respostas fechadas (exemplo: muito, pouco, nada), e outras, que permitissem resposta com base em uma escala ordenada (exemplo: $1=$ nada importante, $\ldots, \ldots, 5=$ muito importante). Foram feitas perguntas também sobre: formação acadêmica, categoria funcional, conhecimento do plano estratégico da FUB (mantenedora da Universidade de Brasília) e do CESPE, bem como a missão, visão e os mecanismos de acompanhamento da evolução estratégia e indicadores para o BSC.

A escolha da estrutura do questionário foi feita para que os objetivos do estudo fossem atingidos.

Com relação ao grau de escolaridade dos respondentes, não foram observadas diferenças significativas nas suas respostas, no que diz respeito aos indicadores do BSC investigados no questionário (aceitando-se um nível de significância de 5\%). Por consequiência, não foi necessário que o estudo fosse realizado separando-se por categoria profissional ou nível de escolaridade. As respostas foram analisadas no todo, sem separação por categoria funcional ou grau de escolaridade.

A entrevista foi feita por meio de questionário aberto, direcionado à Diretoria Geral e Diretoria Executiva do CESPE, tendo apenas uma das diretorias respondido os dados solicitados no instrumento. O conteúdo dos questionamentos especifica o planejamento estratégico do CESPE, ou seja, trazem à luz a descrição do plano estratégico; indicadores de gestão; missão; visão institucional; definição de pontos fortes e pontos fracos, identificação das ameaças, oportunidades e anseios da administração relativos aos ambientes interno e externo do CESPE. Em síntese, revelou a entrevista que o CESPE não tem uma política diferenciada de planejamento estratégico da FUB.

\subsection{Análise e tratamento dos dados}

\section{Variância e desvio-padrão.}

A razão da expressão desvio-padrão: é que a extração da raiz quadrada da variância — que, por ser um quadrado, representa uma grandeza em duas dimensões - transforma o quadrado dos desvios em uma grandeza unidimensional, ou seja, em um comprimento, uma espécie de média geométrica dos desvios, a qual pode ser encarada como um desvio realmente padrão. $\mathrm{Ou}$, em outras palavras, um desvio médio em relação à média do conjunto de dados. 


\section{Homogeneidade das variâncias.}

O bom desempenho dos testes paramétricos exige que as variâncias nele envolvidas sejam homogêneas. Isso não implica, porém, que elas devam ser idênticas, porque nada é exatamente igual em Estatística, havendo sempre uma faixa de tolerância em torno de qualquer suposta igualdade. $\mathrm{O}$ que os testes exigem é que elas não sejam discrepantes a ponto de ultrapassarem determinados limites de tolerância.

\section{Comparações das médias}

Com a finalidade de verificar se os participantes apresentaram diferenças significativas em relação aos indicadores do BSC, os itens do questionário foram agrupados em quatro dimensões, a saber: Missão, Visão, Indicadores e Conhece a existência de mecanismos que permitam acompanhar e avaliar a evolução da estratégia? Em seguida, foram realizados testes de comparações de média considerando os grupos de escolaridade por meio do teste de análise de variância ANOVA one way que compara as médias de mais de dois grupos. Como é pressuposto da ANOVA, foram realizados teste de homogeneidade de variância para cada uma das dimensões comparadas. A estatística de Levene indicou a adequabilidade de realizar as ANOVAs para todas as dimensões. Os resultados das comparações de médias são apresentados nas Tabelas seguintes:

Tabela 2 - Comparação entre os grupos de escolaridade para a Missão

\begin{tabular}{|c|c|c|c|c|c|}
\hline Escolaridade & Média & Desvio-padrão & $\mathbf{F}$ & g.l. & $p$ \\
\hline $2^{\circ}$ completo & 4,50 & 0,52 & \multirow{5}{*}{0,671} & \multirow{5}{*}{44} & \multirow{5}{*}{0,616} \\
\hline $2^{\circ}$ incompleto & 4,75 & 0,35 & & & \\
\hline Graduação & 4,26 & 0,88 & & & \\
\hline Mestrado & 4,28 & 1,08 & & & \\
\hline Doutorado & 4,77 & 0,36 & & & \\
\hline
\end{tabular}

Tabela 3 - Comparação entre os grupos de escolaridade para a Visão

\begin{tabular}{|c|c|c|c|c|c|}
\hline Escolaridade & Média & Desvio-padrão & $\mathbf{F}$ & g.l. & $p$ \\
\hline $2^{\circ}$ completo & 4,39 & 0,80 & \multirow{5}{*}{0,345} & \multirow{5}{*}{44} & \multirow{5}{*}{0,846} \\
\hline $2^{\circ}$ incompleto & 4,50 & 0,71 & & & \\
\hline Graduação & 4,51 & 0,61 & & & \\
\hline Mestrado & 4,53 & 0,73 & & & \\
\hline Doutorado & 4,80 & 0,45 & & & \\
\hline
\end{tabular}


Tabela 4 - Comparação entre os grupos de escolaridade para os Indicadores

\begin{tabular}{l|c|c|c|c|c}
\hline Variáveis & Média & Desvio-padrão & F & g.l. & $\boldsymbol{p}$ \\
\hline $2^{\mathbf{0}}$ completo & 4,16 & 0,76 & & & \\
\cline { 1 - 3 } $2^{\mathbf{o}}$ incompleto & 4,58 & 0,59 & & \\
\cline { 1 - 3 } Graduação & 4,15 & 0,59 & \multirow{2}{*}{0,301} & 0,876 \\
\cline { 1 - 3 } Mestrado & 4,30 & 0,57 & & & \\
\hline Doutorado & 4,34 & 0,68 & & \\
\hline
\end{tabular}

Tabela 5 - Comparação entre os grupos de escolaridade para o conhecimento da existência de mecanismos que permitam acompanhar e avaliar a evolução da estratégia?

\begin{tabular}{|c|c|c|c|c|c|}
\hline Variáveis & Média & Desvio-padrão & $\mathbf{F}$ & g.l. & $p$ \\
\hline $2^{\circ}$ completo & 2,87 & 0,35 & \multirow{5}{*}{0,388} & \multirow{5}{*}{44} & \multirow{5}{*}{0,816} \\
\hline $2^{\circ}$ incompleto & 3,00 & 0,00 & & & \\
\hline Graduação & 2,82 & 0,53 & & & \\
\hline Mestrado & 3,00 & 0,00 & & & \\
\hline Doutorado & 3,00 & 0,00 & & & \\
\hline
\end{tabular}

Conforme pode ser observado pelo teste de significância $(p>0,05)$, não foi observada diferença significativa entre as médias dos grupos de escolaridade para as dimensões citadas nas Tabelas 2, 3, 4 e 5. Esses resultados indicam que a percepção dos respondentes a respeito dessas dimensões é semelhante e independe do grau de escolaridade dos participantes

\subsection{Caracterização da amostra}

O questionário foi distribuído a funcionários e prestadores de serviço, sendo oito da área administrativa (diversas), sete assistentes em administração, cinco técnicos de nível médio, oito técnicos de nível superior, cinco técnicos de informática, três técnicos superior de informática, oito docentes e um respondente que não se identificou pela categoria profissional, totalizando 45 pessoas. Os respondentes são em sua maioria técnico-administrativos. 


\begin{tabular}{ll|c|c|c|c}
\hline & Freqüência & Percentual & $\begin{array}{c}\text { Validação } \\
\text { Percentual }\end{array}$ & $\begin{array}{c}\text { Percentual } \\
\text { Acumulado }\end{array}$ \\
\hline Validos & Administrativo & 8 & 17,8 & 18,2 & 18,2 \\
& Assistente em & 7 & 15,6 & 15,9 & 34,1 \\
& administração & 5 & 11,1 & 11,4 & 45,5 \\
& Técnico nível médio & 8 & 17,8 & 18,2 & 63,6 \\
& Técnico nível superior & 5 & 11,1 & 11,4 & 75,0 \\
& Técnico de informática & 3 & 6,7 & 6,8 & 81,8 \\
& Téc. superior de & 8 & 17,8 & 18,2 & 100,0 \\
& informática & 44 & 97,8 & 100,0 & \\
& Outros & 1 & 2,2 & & \\
& Total & $\mathbf{4 5}$ & $\mathbf{1 0 0 , 0 0}$ & $\mathbf{1 0 0 , 0 0}$ & \\
\hline Não informado & \multicolumn{3}{|c}{}
\end{tabular}

Fonte: Dados da pesquisa

\subsection{O plano estratégico da FUB e do CESPE}

Com o objetivo de verificar a existência de um plano estratégico no CESPE, foram integradas ao questionário algumas questões sobre esta matéria. Neste sentido, foi colocada a questão "Você tem conhecimento sobre a existência de um plano estratégico no âmbito da FUB?". Na mesma linha de pensamento, seguiu-se a pergunta "Você tem conhecimento sobre a existência de um plano estratégico no âmbito do CESPE?' Os resultados encontram-se nas Tabelas 7 e 8:

Tabela 7 - Conhecimento do plano estratégico da FUB

\begin{tabular}{l|l|c|c|c|c}
\hline \multicolumn{2}{l|}{} & Freqüência & Percentual & $\begin{array}{c}\text { Validação } \\
\text { Percentual }\end{array}$ & $\begin{array}{c}\text { Percentual } \\
\text { Acumulado }\end{array}$ \\
\hline Validos & Nada & 25 & 56,6 & 56,6 & 55,6 \\
\hline & Pouco & 17 & 38,8 & 38,8 & 93,3 \\
\hline & Muito & 3 & 6,7 & 6,7 & 100,0 \\
\hline & Total & 45 & 100,0 & 100,0 & \\
\hline
\end{tabular}

Fonte: Dados da pesquisa

É importante observar que, em nível da FUB, 55,6\% dos respondentes não têm nenhum conhecimento do plano estratégico da FUB, 37\% sabem pouco e 6,7\% sabem muito. O percentual dos que não sabe nada sobre planejamento estratégico é relevante.

Tabela 8 - Conhecimento do plano estratégico no CESPE

\begin{tabular}{l|l|c|c|c|c}
\hline \multicolumn{2}{l|}{} & Freqüência & Percentual & $\begin{array}{c}\text { Validação } \\
\text { Percentual }\end{array}$ & $\begin{array}{c}\text { Percentual } \\
\text { Acumulado }\end{array}$ \\
\hline Validos & Nada & 18 & 40,0 & 40,0 & 40,0 \\
\hline & Pouco & 22 & 48,9 & 48,9 & 88,9 \\
\hline & Muito & 5 & 11,1 & 11,1 & 100,0 \\
\hline & Total & 45 & 100,0 & 100,0 & \\
\hline
\end{tabular}


Já com relação ao conhecimento do plano estratégico no CESPE, 40\% dos respondentes nada conhecem, $48,9 \%$ conhecem pouco e apenas $11,1 \%$ conhecem muito. Os que não sabem se existe um plano estratégico somado aos que pouco conhecem é elevado para uma instituição que pretenda fazer uso de uma gestão estratégica com o envolvimento de todos os agentes. Esse desconhecimento pode dificultar a implantação de estratégias, sejam elas quais forem.

Tabela 9 - O estabelecimento de um plano estratégico pode melhorar as relações internas de trabalho

\begin{tabular}{l|l|c|c|c|c}
\hline \multicolumn{2}{l|}{} & Freqüência & Percentual & $\begin{array}{c}\text { Validação } \\
\text { Percentual }\end{array}$ & $\begin{array}{c}\text { Percentual } \\
\text { Acumulado }\end{array}$ \\
\hline Validos & Pouco & 7 & 15,6 & 15,6 & 15,6 \\
\hline & Muito & 38 & 84,4 & 38,8 & 38,8 \\
\hline & Total & 45 & 100,0 & 100,0 & \\
\hline
\end{tabular}

Fonte: Dados da pesquisa

A maioria dos servidores, a saber, $84,4 \%$ concordam que o estabelecimento de um plano estratégico pode melhorar muito as relações internas de trabalho. Os maiores entusiastas dessa afirmativa são os habilitados do 2..$^{\circ}$ Grau, Graduação e Mestrado. Os habilitados no Doutorado são mais comedidos em afirmar isto, conforme se pode perceber na tabela abaixo.

Tabela 10 - Habilitações acadêmicas - plano das relações internas do trabalho

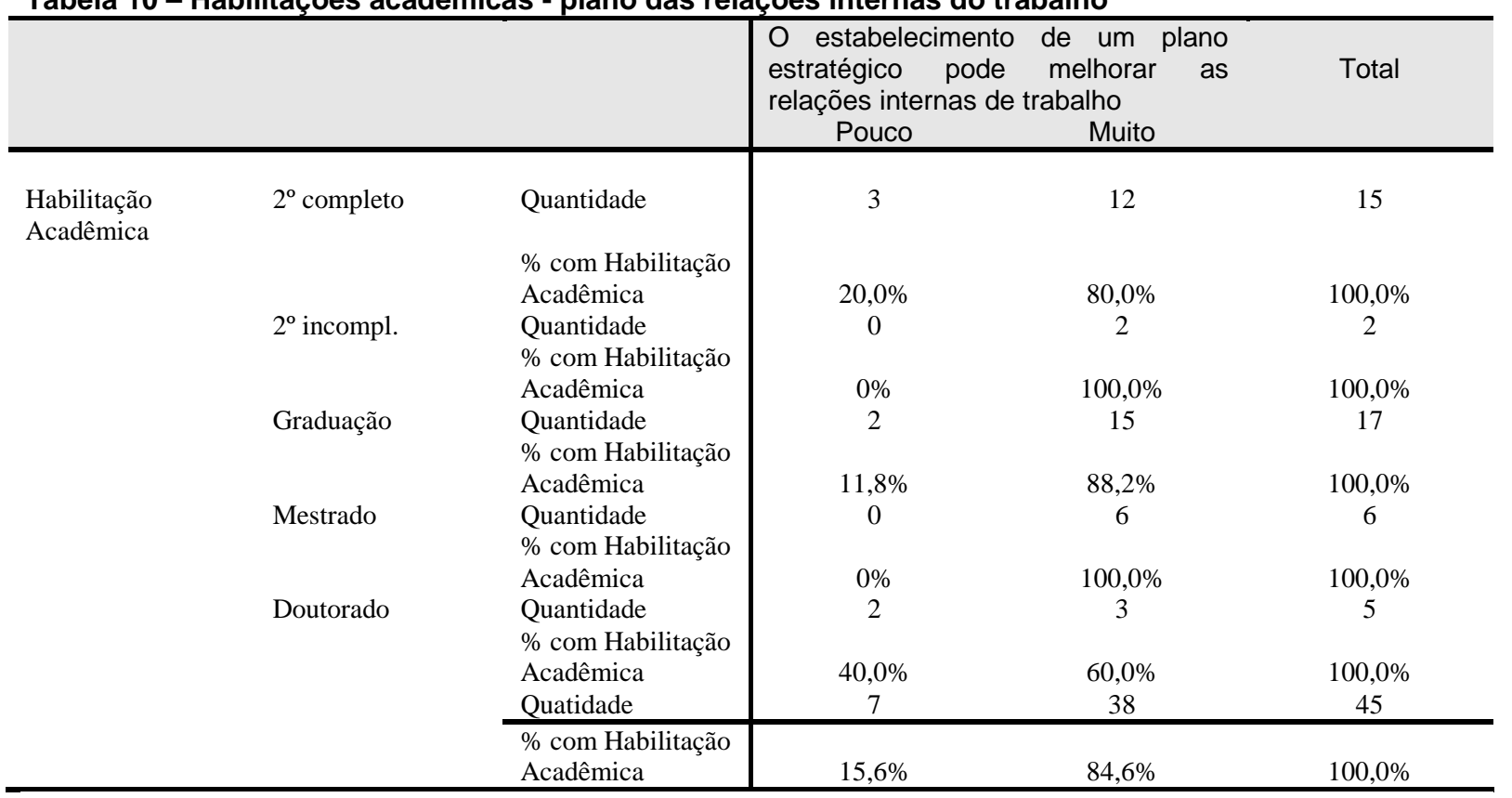




\subsection{Missão}

Na tentativa de perceber se os docentes e funcionários do CESPE conheciam a missão do centro, foi-lhes solicitado, numa escala de 1 = nada adequada a $5=$ muito adequada, o grau de adequabilidade de um conjunto de afirmações, que podem muito bem descrever o propósito do CESPE, identificar o negócio que a organização participa no presente e no futuro, bem como delinear a estratégia a ser seguida, incorporar valores compartilhados e os comportamentos esperados de seus colaboradores.

$\mathrm{Na}$ análise da Tabela 11 observou-se que as médias para as alternativas ficaram próximas o que significa que todas são aceitáveis. Porém, o Desvio Padrão indica que as alternativas mais adequadas são aquelas mais próximas de zero. Nesse sentido, as afirmações que melhor traduzem a missão do CESPE, por ordem decrescente de adequabilidade, são:

\footnotetext{
$1 .^{\circ}$ - "Prestar serviços com qualidade em todo o Brasil";

2. - " "Criar, difundir e transmitir cultura e tecnologia e promover o desenvolvimento da região em que se insere";

3. - "Transmitir conhecimentos a outrem".
}

\section{Tabela 11 - Missão do CESPE}

\begin{tabular}{|c|c|c|c|c|c|}
\hline & $\mathrm{N}$ & Minimo & Máximo & Média & $\begin{array}{l}\text { Desvio } \\
\text { Padrão }\end{array}$ \\
\hline $\begin{array}{l}\text { Fazer parte de uma instituição de ensino superior pública com } \\
\text { qualidade, competitividade, utilidade e notoriedade }\end{array}$ & 45 & 1 & 5 & 4,36 & 1,048 \\
\hline Prestar serviços com qualidade em todo o Brasil & 45 & 1 & 5 & 4,62 & 834 \\
\hline Fazer parte de uma equipe de profissionais altamente qualificados & 44 & 1 & 5 & 4,39 & 1,104 \\
\hline Transmitir conhecimentos a outrem & 43 & 1 & 5 & 4,37 & 1,001 \\
\hline $\begin{array}{l}\text { Criar, difundir e transmitir cultura e tecnologia e promover o } \\
\text { desenvolvimento da região em que se insere }\end{array}$ & 45 & 1 & 5 & 4,44 & 867 \\
\hline $\begin{array}{l}\text { Fazer parte de uma instituição de ensino superior público de } \\
\text { referência nacional }\end{array}$ & 44 & 1 & 5 & 4,36 & 1,163 \\
\hline
\end{tabular}

Fonte: Dados da pesquisa

\subsection{Visão}

Na tentativa de perceber se os docentes e funcionários do CESPE conheciam a visão da empresa, foi-lhes solicitado, numa escala de 1 = nada adequada a $5=$ muito adequada, o grau de adequabilidade de um conjunto de afirmações, que podem muito bem descrever o estado futuro a que o 
CESPE pretende chegar, ou seja, a opinião deverá expressar como a organização quer ser percebida pelo mundo.

Como demonstra a Tabela 12 pode-se afirmar, mantido o mesmo critério utilizado na tabela 5.8, que as três indicações para a visão da empresa, por ordem decrescente de adequabilidade são:

1. - "Ser uma organização de excelência na região em que se insere";

2. - "Ser um pólo nacional de referência";

3. - "Criar, difundir e transmitir cultura, tecnologia e promover o desenvolvimento da região em que se insere".

Tabela 12 - Visão

\begin{tabular}{|c|c|c|c|c|c|}
\hline & $\mathrm{N}$ & Minimo & Máximo & Média & $\begin{array}{l}\text { Desvio } \\
\text { Padrão }\end{array}$ \\
\hline Ser uma organização de excelência na região em que se insere & 45 & 3 & 5 & 4,71 &, 589 \\
\hline $\begin{array}{l}\text { Ser parte de uma instituição de ensino superior pública com } \\
\text { qualidade, competitividade e notoriedade }\end{array}$ & 45 & 1 & 5 & 4,42 & ,965 \\
\hline $\begin{array}{l}\text { Criar, difundir e transmitir cultura, tecnologia e promover o } \\
\text { desenvolvimento da região em que se insere }\end{array}$ & 45 & 1 & 5 & 4,40 & ,963 \\
\hline $\begin{array}{l}\text { Ser um centro de referência nacional que faz parte de uma } \\
\text { instituição pública }\end{array}$ & 45 & 1 & 5 & 4,44 & 1,035 \\
\hline Ser um pólo nacional de referência & 45 & 2 & 5 & 4,53 & ,894 \\
\hline
\end{tabular}

Fonte: Dados da pesquisa

\subsection{Mecanismos de acompanhamento e avaliação da estratégia}

As respostas obtidas da questão "Conhece a existência de mecanismos que permitam acompanhar e avaliar a evolução à estratégia" registraram 2,89\% de média, desvio padrão de 0,383 e significância de 0,972 .

\subsection{Indicadores para o Balanced Scorecard}

Segundo Kaplan e Norton (1997), a seleção de indicadores objetiva identificar os que melhor comunicam o significado da estratégia adotada pela organização. A escolha desses indicadores deve ser efetuada, tomando por base alguns critérios, tais como: ligação à estratégia, acessibilidade, 
relevância, etc. Recomenda-se não escolher mais de dois indicadores para cada objetivo estratégico.

No presente estudo, depois de selecionados vários indicadores por meio da literatura disponível sobre estudos de caso, ofereceu-se aos servidores do CESPE escolherem aqueles que melhor expressassem a realidade do CESPE, atribuindo grau de importância (escala de 1 = nada importante a 5 = muito importante). A opção por respostas fechadas está relacionada ao fato dos indicadores estarem relacionados com os objetivos estratégicos definidos para o CESPE. Diante dos indicadores apresentados aos respondentes e considerando o grau de importância que cada um lhes atribuiu, foi calculada a respectiva média, bem como o desvio padrão de cada indicador:

Tabela 13 - Indicadores na perspectiva financeira de Kaplan e Norton (1997) escolhidos para o CESPE

\begin{tabular}{l|r|r|r|r|r}
\multicolumn{1}{c|}{ INDICADORES PARA A PERSPECTIVA FINANCEIRA } & N & Minimo & Máximo & Média & $\begin{array}{r}\text { Desvio } \\
\text { Padrão }\end{array}$ \\
\hline Percentual de aumento das receitas & 44 & 1 & 5 & 4,18 & 1,018 \\
Tempo médio de avaria de equipamentos & 44 & 2 & 5 & 3,95 &, 963 \\
Custos com pessoal/custos totais & 45 & 1 & 5 & 4,31 & 1,019 \\
Custos com pesquisa/custos totais & 44 & 1 & 5 & 4,00 &, 988 \\
Custos de treinamento/custos totais & 45 & 1 & 5 & 4,53 &, 842 \\
Custos com atividade fim/custos totais & 45 & 1 & 5 & 4,20 & 1,036 \\
Custos por evento/custos totais & 45 & 2 & 5 & 4,38 &, 936 \\
Custos por aluno & 45 & 1 & 5 & 3,76 & 1,171 \\
Custos por professores & 45 & 1 & 5 & 4,24 &, 957 \\
Custos por funcionário do quadro e extra-quadro & 45 & 1 & 5 & 4,18 & 1,051 \\
Receita oriunda de novos clientes & 45 & 1 & 5 & 4,20 & 1,014 \\
Receita oriunda de novos produtos e serviços & 45 & 1 & 5 & 4,00 & 1,108 \\
Rentabilidade dos clientes medida pelo sistema ABC & 44 & 1 & 5 & 3,84 & 1,098 \\
Porcentagem de clientes não-lucrativos & 45 & 1 & 5 & 4,13 & 1,079 \\
\hline
\end{tabular}

Fonte: Dados da pesquisa

Tabela 14 - Indicadores na perspectiva clientes de Kaplan e Norton (1997) escolhidos para o CESPE

\begin{tabular}{|c|c|c|c|c|c|}
\hline \multicolumn{6}{|l|}{ INDICADORES PARA A PERSPECTIVA CLIENTES } \\
\hline Lucro por segmento de cliente & 45 & 2 & 5 & 4,02 & ,965 \\
\hline Participação de mercado nos segmentos alvo & 45 & 1 & 5 & 4,22 & ,974 \\
\hline Porcentagem de clientes não-lucrativos & 45 & 2 & 5 & 4,16 & ,952 \\
\hline Número de clientes estratégicos & 44 & 2 & 5 & 4,52 & ,821 \\
\hline $\begin{array}{l}\text { Pesquisa entre os clientes estratégicos sobre conhecimento e preferência da } \\
\text { marca UnB/CESPE }\end{array}$ & 45 & 1 & 5 & 4,38 & ,984 \\
\hline Custo por cliente conquistado & 45 & 1 & 5 & 4,22 & 1,064 \\
\hline Número de recomendações a novos clientes & 45 & 1 & 5 & 4,09 & 1,041 \\
\hline $\begin{array}{l}\text { Número de novos clientes conquistados com base em recomendações dos } \\
\text { clientes existentes }\end{array}$ & 45 & 2 & 5 & 4,18 & 1,029 \\
\hline Número de testemunhos de clientes fiéis & 45 & 2 & 5 & 4,24 & ,981 \\
\hline Número de sugestões de clientes fiéis para melhorias nos produtos e serviços & 45 & 2 & 5 & 4,29 & 944 \\
\hline Retenção de clientes & 45 & 2 & 5 & 4,36 & ,933 \\
\hline Número de acordos para o desenvolvimento conjunto de serviços & 45 & 1 & 5 & 4,13 & 1,014 \\
\hline
\end{tabular}

Fonte: Dados da pesquisa 
Tabela 15 - Indicadores na perspectiva dos processos internos de Kaplan e Norton (1997) escolhidos para o CESPE

\section{INDICADORES PARA A PERSPECTIVA DOS PROCESSOS INTERNOS}

\begin{tabular}{l|r|r|r|r|r}
\hline Percentual de clientes não lucrativos & 45 & 1 & 5 & 3,78 & 1,241 \\
Número de clientes estratégicos & 45 & 2 & 5 & 4,24 & 1,004 \\
Consciência da marca/preferência & 45 & 1 & 5 & 4,47 &, 894 \\
Contribuição por segmento & 45 & 1 & 5 & 3,98 &, 988 \\
Número de clientes especiais & 45 & 1 & 5 & 4,20 &, 968 \\
Valor vitalício dos clientes & 45 & 1 & 5 & 4,09 & 1,083 \\
Aumentar o número de clientes & 44 & 2 & 5 & 4,48 &, 821 \\
Identificação de oportunidades & 45 & 2 & 5 & 4,56 &, 725 \\
Reduzir duração do ciclo de desenvolvimento & 44 & 1 & 5 & 4,09 & 1,030 \\
Descobrir novas oportunidades & 44 & 2 & 5 & 4,52 &, 849 \\
\hline
\end{tabular}

Fonte: Dados da pesquisa

Tabela 16 - Indicadores na perspectiva aprendizagem e crescimento de Kaplan e Norton (1997) escolhidos para o CESPE5

\section{INDICADORES PARA A PERSPECTIVA APRENDIZAGEM E CRESCIMENTO}

\begin{tabular}{l|r|r|r|r|r}
\hline Prontidão do capital humano & 44 & 2 & 5 & 4,50 &, 731 \\
Rotatividade do pessoal chave & 44 & 2 & 5 & 4,32 &, 829 \\
Resultados de pesquisa sobre cultura dos empregados & 44 & 1 & 5 & 4,36 & 1,036 \\
Porcentagem dos objetivos dos empregados vinculados aos processos de & 44 & 1 & 5 & 4,07 & 1,129 \\
clientes e respectivos indicadores de resultados do BSC & 44 & 1 & 5 & 3,86 & 1,091 \\
Acesso do empregado ao sistema de gestão do conhecimento do cliente & 44 & 1 & 5 & 4,18 &, 947 \\
Objetivos dos empregados, conectados ao BSC & 44 & 2 & 5 & 4,39 &, 895 \\
Habilidades multidisciplinares & 44 & 2 & 5 & 4,55 &, 791 \\
Cultura de criatividade e inovação & 36 & & & \\
Valid N (listwise) & &
\end{tabular}

Fonte: Dados da pesquisa

A melhor alternativa para escolha dos indicadores deverá recair sobre aqueles que obtiverem o desvio padrão mais baixo, mais próximo de zero. As respostas das tabelas permitem escolher, para cada objetivo estratégico, os indicadores que melhor traduzem o acompanhamento e a avaliação da evolução da estratégia, na opinião dos inquiridos, caso venha a ser implantada esta metodologia pelo CESPE.

Isso não quer dizer que esses indicadores sejam os mais indicados. Quem decidirá sobre os melhores e mais adequados indicadores serão os gestores do CESPE, como coordenadores do processo de implantação do BSC, caso ele venha a ser adotado como metodologia estratégica. Outros indicadores mais representativos do consenso podem ser listados, pois a simulação feita neste trabalho é hipotética e em conformidade com os parâmetros estabelecidos por Kaplan e Norton. 


\subsection{Visita a Órgãos Públicos que implantaram o BSC}

Tomou-se conhecimento da existência, em Brasília, de três órgãos públicos que vivenciaram a implantação da metodologia do Balanced Scorecard, o Banco do Brasil, a Empresa Brasileira de Pesquisa Agropecuária (EMBRAPA) e a Receita Federal. Era intenção dos realizadores do presente estudo visitar estas organizações com o propósito de conhecer as experiências e os resultados alcançados, bem como conhecer os processos de mudança e as técnicas envolvidas com os bastidores das implantações. Todavia, a exigüidade do tempo não permitiu o cumprimento integral do intento. Os autores visitaram dois dos três Órgãos, a saber, Banco do Brasil e a EMBRAPA, tendo a escolha destes se baseado na experiência de sucesso de um e de insucesso do outro, com a implantação da nova metodologia.

\subsubsection{A experiência do Banco do Brasil}

Entrevistada a gerente de Estratégia e Planejamento Empresarial do Banco do Brasil, Fátima Lima, informou que o BSC foi concebido para o banco como um todo, em 1999 e, efetivamente implantado em 2001. Como primeiro passo dessa implantação foi realizado o ciclo de planejamento e abordado os cenários interno e externo do Banco do Brasil. Na ocasião foi apresentado: a) arquitetura estratégica; b) arquitetura de governança; c) estratégia corporativa para o horizonte de 5 anos, bem como o Plano Diretor e Plano de Mercados do banco, que surgiram em conseqüência da implantação do BSC.

Em 2001 o BSC foi apresentado por meio de um painel estratégico, composto de objetivos estratégicos, contendo indicadores de desempenho passíveis de mensuração, com metas a serem atingidas para o período avaliatório e apresentação dos objetivos vinculados às perspectivas do Balanced Scorecard e suas relações de causa-efeito; foi feita também uma análise dos softwares de mercado existentes e seus aplicativos piloto e workshops. Segundo a entrevistada, um aplicativo foi desenvolvido pela Diretoria de Tecnologia do Banco do Brasil, para fazer o acompanhamento dos resultados dos indicadores de desempenho e comparar os resultados com as metas estabelecidas. Esse aplicativo é manipulado por um número restrito de funcionários por área. As áreas designam funcionários para fazer a edição dos resultados, que são revisados posteriormente por um Gerente Executivo (funcionário que exerce em caráter efetivo cargo em nível executivo). Após a edição e a revisão, a Diretoria de Estratégia e Organização, responsável pelo Balanced Scorecard corporativo, publica os resultados do 
Plano Diretor e do Plano de Mercados. O mapa estratégico e os resultados ficam disponíveis para os funcionários que exercem cargos em nível de Administração (a partir de Gerente de Divisão).

Já em 2004, o BSC foi disponibilizado para todo o Banco do Brasil por meio da Intranet e os seus resultados, computados trimestralmente. Como política de alinhamento do BSC foi adotada uma postura de revisão das metas inicialmente previstas, feito o planejamento das melhores projeções e reflexões sobre as metas previstas, buscando assim o equilíbrio das metas, a integração das equipes, a flexibilização das postulações, a verificação sobre o atingimento das metas e a revisão das estratégias para o período de cinco anos.

Segundo Fátima o BSC foi delineado em duas vertentes: a do Plano Diretor, que abordava as perspectivas: financeira, clientes, sociedade, processos internos e comportamento organizacional; e a do Plano de Mercados, organizado por pilares: varejo, atacado, governo. O Plano de Mercados orienta as ações a serem realizadas nos 3 pilares e possui categorias e indicadores nas perspectivas financeira, sociedade e clientes.

Os resultados positivos alcançados no BSC são objeto de acordo trabalhista e impactam no reconhecimento e nos benefícios dos acordos de trabalho com o sindicato dos bancários. Para cada objetivo de trabalho o aplicativo criado pelo banco apresenta um ou mais indicadores. À direita, possui uma coluna com três alternativas: 1) não atingiu, faltam 10\%, cor vermelha; 2) atingiu parcialmente, cor amarela; 3) atingiu totalmente, cor verde. As cores são utilizadas para sinalizar se foram ou não atingidos os objetivos com base nos indicadores.

No BSC corporativo, cada área fica responsável pelas informações relativas aos indicadores sob sua responsabilidade. Algumas áreas do Banco possuem o seu próprio Balanced Scorecard, criado a partir do seu Planejamento Estratégico, que está alinhado à Estratégia Corporativa, e isso possibilita à empresa uma melhor avaliação das questões internas e externas, mais transparência na gestão estratégica e melhores iniciativas para sanar os problemas internos, envolvendo as pessoas no dia a dia da empresa. Atualmente a diretoria do BB está trabalhando para comprar software de empresa externa, para que não seja necessário importar dados de outras bases das unidades corporativas, pois hoje o processo é feito manualmente, ou seja, importando os dados de cada unidade descentralizada para a central.

Além de fornecerem informações de apoio à decisão, a construção dos Painéis Estratégicos atende à recomendação da Auditoria da Secretaria Federal de Controle Interno, da Controladoria Geral da União e do Tribunal de Contas da União. 


\subsubsection{A experiência da EMBRAPA}

Foi entrevistado um dos principais Pesquisadores Sênior da EMBRAPA que afirmou estar a organização trabalhando desde 1989, com a elaboração de Planos Estratégicos, conhecido internamente como PDE - Plano Diretor da Embrapa e PDUS Planos Diretores das Unidades, objetivando definir rumos e direcionamentos estratégicos institucionais, de médio e longo prazo.

A empresa implantou um novo instrumento de gestão, com base no BSC, chamado de Modelo de Gestão Estratégica (MGE). O MGE foi implantado com os objetivos de traduzir a missão, visão e os objetivos da EMBRAPA em iniciativas e ações estratégicas, permitindo a vinculação das metas institucionais previstas no Plano Diretor às metas das Unidades Descentralizadas, Unidades Centrais, equipes e pessoas. Foram criados também indicadores de desempenho para monitoramento e acompanhamento contínuo do desempenho da organização. O processo foi validado pela Diretoria Executiva, tendo sido aprovado posteriormente pelo seu Conselho de Administração.

A Embrapa constituiu os MGEs para a corporação e para as Unidades Descentralizadas - Uds. O MGE utilizou um sistema de medição de desempenho organizacional, que orientou e monitorou os rumos que deveriam ser perseguidos num determinado período de tempo, com vistas a cumprir a Missão e a Visão concebida nos planos estratégicos.

Foi identificado um fator inovador na perspectiva organizacional financeira do método BSC original de Kaplan e Norton para institucional e financeira. Essa adaptação do método BSC resolveu o problema de avaliar o desempenho de uma organização pública com base em aspectos puramente financeiros (lucro, ROI, etc.), passando a considerar o seu impacto na sociedade.

Disse o nosso entrevistado que a construção e implementação do MGE da Embrapa teve início em agosto de 1996, como resultado do pós-doutorado de um pesquisador da empresa, que na época exercia suas atividades na Secretaria de Gestão e Estratégia (SGE), responsável pela gestão estratégica da empresa. O resultado desse trabalho foi apresentado à Diretoria Executiva (DE), que, convencida dos seus benefícios no cumprimento da missão e o alcance da visão delineados no Plano Diretor, aprovou o projeto.

Não sendo considerada necessária a contratação de consultoria externa, com knowhow na construção, implementação e acompanhamento do método BSC, foi formada 
uma equipe (Equipe MGE), composta de técnicos da própria empresa e designada pela Diretoria Executiva, com o objetivo de implantar em toda a empresa, para teste e adaptação do método BSC. A primeira tarefa desta equipe foi construir, de forma participativa, um instrumento de gestão ajustado à sua cultura, valores e características, para assim possibilitar o planejamento, execução, acompanhamento e avaliação das estratégias preconizadas no Plano Diretor da Embrapa e das Unidades (PDU).

Segundo o nosso entrevistado, o BSC pode ser bem ou mal administrado, dependendo do grupo que gerencia o projeto, a liderança exercida pelo dirigente sobre os dirigidos, a cultura institucional e uma série de outros fatores que fazem parte do estilo de gerenciamento. Segundo ele, instituições de pesquisa como a EMBRAPA, ou mesmo a UnB, tendem a ser muito conservadoras em seus processos gerenciais. Disse ele que o processo foi introduzido de forma um tanto quanto impositiva por parte do gerente, inclusive no que se refere a ameaças de demissão de gerentes em cargo de confiança, caso os procedimentos não fossem seguidos, o que ocasionou a emergência de resistências passivas de parte significativa do corpo técnico e gerencial.

Disse que alguns grupos de pesquisadores e de gerentes de Unidades de pesquisa estavam entusiasmados, mas a maioria passou a encarar o BSC como uma intervenção a mais, pois já existia um Plano Diretor contendo os objetivos estratégicos da empresa desde o ano 2000, que foi utilizado por cerca de 4 anos. A introdução do BSC foi considerada redundante, pois ao invés de ser implantado e utilizado de forma complementar, consolidando o modelo de gestão anterior, veio a constituir-se num novo plano estratégico, com redefinição de objetivos, sem extinguir o modelo antigo, ocasionando sobreposição de objetivos e, por isso, não correspondeu às expectativas vigentes. Ademais, o MGE criou uma nova estrutura de poder, os gerentes de objetivos estratégicos do MGE, sem que a estrutura gerencial anterior fosse desmobilizada.

Em 2004, foi feita uma avaliação de todos os sistemas gerenciais da empresa, tendo sido encaminhado questionário para as gerencias da Sede e das UDs sobre uma série de questões, inclusive no que se refere à percepção de mudança na melhoria do desempenho. A maior parte dos respondentes, cerca de $70 \%$ opinou não ter havido mudanças substanciais no que se refere à melhoria do desempenho da gestão estratégica e $65 \%$ identificou a necessidade de ajustar o modelo. A partir desse resultado, o BSC como metodologia de gestão estratégica foi extinta pela diretoria executiva da época. 


\subsection{3 - Viés Entre a Experiência das Empresas e a Metodologia BSC}

Kaplan e Norton (1997), fazem referência a quatro etapas para implantação do BSC: a) Definição da Arquitetura de Indicadores; b) Consenso em função dos Objetivos Estratégicos; c) Escolha e elaboração dos indicadores; d) Elaboração do plano de implementação. Ressalta, ainda, que o processo de implantação do BSC não poderá exceder a 16 semanas, tempo este que deverá ser ocupado com a realização de entrevistas, workshops e reuniões de subgrupos para propiciar a conscientização, refletir sobre a estrutura evolutiva do BSC e as estratégias a serem seguidas. Segundo os autores, "o arquiteto do BSC passa a desempenhar um papel de staff e facilitação, ajudando a programar as reuniões de subgrupos e prestando assistência na realização dessas reuniões".

No caso do Banco do Brasil, foi entrevistada uma gerente de planejamento estratégico. Para tanto se utilizou questionário estruturado com questões abertas, tendo a referida gerente apresentado em power point os procedimentos relativos a implantação do BSC naquela instituição, bem como as causas e conseqüências da adoção da nova metodologia. Entendeu-se que lá havia presente os pré-requisitos necessários a implantação do BSC, ou seja, definidos a missão, visão, objetivos e metas a serem alcançadas.

Segundo a entrevistada, a nova metodologia teve como consequiência a implantação de dois planos, o Plano Diretor e o Plano de Mercados. Desta forma, entendeu-se que os pré-requisitos sugeridos por Kaplan e Norton foram observados, inclusive no que se refere à realização de workshops e reuniões de grupos para viabilizar a conscientização da metodologia implantada.

Com relação a EMBRAPA, entendeu-se que a empresa se dedica à pesquisa, com quadro de pesquisadores voltados essencialmente para pesquisa científica, e que demanda, às vezes, longo espaço de tempo e recursos financeiros para ir à busca de conclusões e à obtenção de resultados favoráveis, o que não se enquadraria na delimitação de curto prazo, digamos, na perspectiva de cinco anos, ou até dez anos. Muitas pesquisas demandam décadas para a obtenção de algum resultado positivo ou mensurável.

Deve ser considerado também o fato de que os pesquisadores não têm, na sua grande maioria, experiência na administração pública e por vezes estes ocupam cargos hierárquicos dentro da empresa, sem, contudo, ter o devido preparo para lidar com a implantação de um plano estratégico do tipo BSC. Essa ferramenta exige que o processo seja construído de forma conjunta com a administração superior e com os colaboradores, envolvendo até mesmo os mais humildes cargos da esfera administrativa, não permitindo, 
portanto, posturas de imposição ou atitudes impensadas, principalmente por parte da administração superior.

Outro fator a se considerar é a possível sobreposição de objetivos e metas, quando já existe um plano estratégico em execução na organização. Deve-se tomar o cuidado de, uma vez constatada a sobreposição de objetivos e metas, tornar nula a que menos atender aos objetivos da organização.

Uma organização bem estruturada é um conjunto de processos de trabalho bem articulados. Com a boa articulação obtém-se um fim que está associado aos interesses dos clientes e da empresa. Quando alguns desses processos não funcionam adequadamente, toda a eficácia organizacional pode declinar.

Por trás de qualquer processo existem pessoas que tomam decisão e para tomar a decisão acertada é necessário que os sistemas de informação da empresa sejam capazes de apoiar as pessoas que decidem. Nesse sentido, é fundamental o apoio dos sistemas de informação à tomada de decisão e a escolha do planejamento adequado para as finalidades a que se destina a instituição.

No que concerne ao planejamento estratégico no âmbito da FUB, observou-se que 93,3\% dos entrevistados sabem pouco ou nada. No âmbito do CESPE o percentual é igual a $83,9 \%$. Esses dados mostram o quão pouco a comunidade sabe sobre planejamento estratégico, o que indica a necessidade de uma melhor divulgação do planejamento interno da instituição. Essa conscientização pode ser feita por meio de palestras e outros meios de comunicação disponíveis, principalmente pela participação dos colaboradores na elaboração do planejamento estratégico. Neste contexto há que se cuidar para que o colaborador esteja familiarizado com a missão, visão, objetivos e metas estratégicas e que perceba suas atividades do dia-a-dia integradas aos objetivos e metas institucionais.

Quanto a pergunta se um plano estratégico pode melhorar pouco ou muito as relações internas de trabalho, a opinião de $84,4 \%$ dos colaboradores foi favorável a alternativa "muito", o que demonstra credibilidade dos colaboradores à adoção de um planejamento estratégico como solução para tornar a instituição mais humana.

Quanto a missão do CESPE, percebeu-se que os colaboradores vêem com otimismo a possibilidade de o Centro ir muito além de seus limites geográficos e desempenhar com qualidade seus serviços no mercado nacional.

Esta percepção fica confirmada no entendimento do que deve ser a "visão" institucional do CESPE: "Ser uma organização de excelência na região em que se insere" e "ser um pólo nacional de referência". A razão de a primeira opção ter sido apontada pelos 
colaboradores como a mais adequada pode estar embasada no desconhecimento do sentido da visão institucional, pois na "missão" a primeira colocada foi "Prestar serviços com qualidade em todo o Brasil" e não apenas na região em que se insere. Observa-se, entretanto, que a opção nacionalista está presente em segundo lugar na "visão" institucional: "Ser um pólo nacional de referência" o que indica uma inversão de valores.

A opinião dos respondentes considera importante a existência de mecanismos que permitam acompanhar e avaliar a evolução da estratégia, o que indica haver uma predisposição dos colaboradores em aceitar uma metodologia de planejamento estratégico que norteie a organização para novos horizontes, com melhores perspectivas.

Os indicadores na perspectiva financeira, clientes, processos internos e aprendizagem e crescimento deverão ser escolhidos em conformidade com os objetivos delineados no planejamento estratégico. Isso não quer dizer que os indicadores apontados neste trabalho sejam os mais adequados. Quem vai decidir quais os indicadores mais adequados serão os gestores da organização - com o apoio de uma assessoria técnica especializada - que estarão coordenando o processo e listando talvez outros indicadores mais representativos do consenso e mais ajustados aos objetivos e metas institucionais.

A simulação realizada neste trabalho manteve conformidade com os parâmetros estabelecidos por Kaplan e Norton para implantação do BSC. 


\section{CONSIDERAÇÕES FINAIS}

As organizações da atualidade têm que sobreviver num mercado cada vez mais competitivo e global. Diante este novo desafio, elas devem possuir ferramentas de gestão fidedignas, que lhes permitam a transição para uma gestão estratégica, orientada permanentemente para sua finalidade.

No presente estudo foi possível verificar que o Balanced Scorecard pode constituir uma dessas ferramentas, pois permite: criar maior compreensão do papel da estratégia nas organizações; traduzir e tornar clara a visão e a estratégia; fazer a ligação entre os objetivos e indicadores estratégicos; estabelecer objetivos e fazer o alinhamento da estratégia e propiciar maior feedback e a aprendizagem estratégica.

O BSC faz uso de quatro perspectivas para cumprir seus objetivos: financeira, dos clientes, dos processos internos e de aprendizagem e crescimento.

A revisão de literatura deste estudo constatou que o BSC pode vir a ser um instrumento inovador em todo o sistema público e a sua utilização vai depender essencialmente de uma mudança cultural no serviço público. Entretanto, para sua utilização será necessária a introdução de algumas modificações, em especial no que se refere à perspectiva financeira e do cliente, pois no serviço público prevalece a preocupação social com a clientela.

O Balanced Scorecard permitiria consolidar a gestão estratégica do CESPE, funcionando como um instrumento da sua missão e visão. Verificou-se, ainda, que a sua utilização introduziria a idéia na cultura organizacional de que a estratégia é um labor de todos (gestores, docentes e colaboradores).

Destacam-se três razões que inviabilizariam a implantação da metodologia Balanced Scorecard numa organização, fosse ela privada ou pública: i) a incompreensão dos conceitos e processos desenvolvidos por Kaplan e Norton; ii) a prevalência do conservadorismo em nível exacerbado a ponto de privar os gestores da visão dos benefícios oferecidos pelo novo sistema de gerenciamento estratégico e iii) a desmobilização ou o indiferentismo dos diversos atores da organização em relação a missão, visão, objetivos e metas institucionais.

O presente estudo constatou que o CESPE precisa vencer a questão do desconhecimento por parte de seus colaboradores das estratégias adotadas, bem como constatou que o sistema de mensuração de desempenho adotado pela FUB e vias de regra pelo CESPE se reveste das características tradicionais, nas quais prevalecem apenas os indicadores 
contábeis e financeiros, repetidas vezes mencionados neste trabalho insuficientes como suporte às decisões de médio e longo prazo.

O CESPE como um centro da Universidade de Brasília, está sujeito às normas do serviço público, que como tal, requer adaptação na aplicação do BSC com a inserção de novas perspectivas que melhor expressem o compromisso da instituição com a sociedade.

O CESPE, por sua natureza de arrecadador de recursos não teria dificuldades em ajustar-se à concepção original de Kaplan e Norton. Como conseqüência não haveria a necessidade da introdução de modificações ao modelo original. Caso esta mudança venha a se concretizar, deverá ser realizada em estreita consonância com a Secretaria de Planejamento da FUB, unidade responsável pelo planejamento, avaliação, desenvolvimento organizacional, sistematização e divulgação interna e externa de informações, relatos e indicadores das ações das unidades da UnB.

Faz-se mister assinalar a incontestável competência do CESPE na geração de recursos - o que lhe outorgou o status de principal sustentáculo da FUB num cenário de parcos recursos do Tesouro Nacional. Seu sucesso atual está fundamentado na atuação dedicada de seu corpo funcional. Entretanto, caso não seja repensado um diferencial qualitativo dos demais concorrentes, poderá ser surpreendido pela perda da parcela de mercado e da credibilidade que já conquistou.

A implantação do BSC no seu dia-a-dia poderá acrescentar ao CESPE uma visão mais abrangente do seu ambiente externo e lhe aparelhará para enfrentar as adversidades imprevistas, tornando assim, melhor o que, a bem da verdade, é incontestavelmente satisfatório. 


\section{REFERÊNCIAS}

Bressan, Flávio. O método do estudo de caso. Administração On Line. Fundação Escola de Comércio Álvares Penteado - FECAP. São Paulo, v. 1, n. 1, 2000. Disponível na Internet: <http://www〉. Acesso em 14/11/2006.

Campos, V. F. Gerenciamento de Rotinas. INDG - Instituto de Desenvolvimento Gerencial Disponível em http://www.indg.com.br/falconi/request_mensagens.asp?id=126. Acesso em $11 / 6 / 07$.

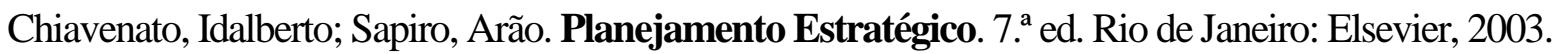

Cimino, J. C. S. Implantação do balanced scorecard (BSC) em pequenas empresas: um estudo de caso em uma pequena empresa de serviços em juiz de fora - MG. Florianópolis, 2004. 90 pg. Disponível na Internet: http://www.inf.ufsc.br/ cezar/indexorientações.html. Acesso em 22/9/2006.

Galas, Eduardo Santos e Forte, Sérgio H. A. C. Fatores que interferem na implantação de um modelo gestão estratégica baseado no Balanced Scorecard: estudo de caso em uma instituição pública. In: Read, ed. 41 vol. 10 n. ${ }^{\circ}$, set-out 2004. Disponível na Internet <http://www.>

Günter, H. Desenvolvimento de Instrumento para levantamento de dados. In: Pasquali, L. (Org.). Teoria e métodos de medida em ciências do comportamento. Brasília: UnB-INEP, 1996. cap.15. p. 387-403.

Herrero Filho, Emílio. Balanced scorecard e a gestão estratégica: uma abordagem prática.. 5. ${ }^{a}$ ed. Rio de Janeiro: Elsevier, 2005.

Kaplan, Robert S. e Norton, David P. A Estratégia em ação: Balanced Scorecard. 13. ${ }^{a}$ ed. Rio de Janeiro: Campus, 1997. p. 344.

Kaplan, Robert S. e Norton, David P. A estratégia em ação: Balanced Scorecard. 22. a ed. Rio de Janeiro: Elsevier, 1997.

Kaplan, Robert S. e Norton, David P. Mapas Estratégicos - Balanced Scorecard: convertendo ativos intangíveis em resultados tangíveis. 8. a ed. Rio de Janeiro: Elsevier, 2004.

Kaplan, Robert S. e Norton, David P. Organização orientada para a estratégia. 3. ${ }^{a}$ ed. Rio de Janeiro: Campus, 2000. p. 411.

Lima, Edla M. B. et al. Balanced Scorecard (BSC) - uma visão metodológica para o acompanhamento de sua implementação. In: Revista do Serviço Público, ano 54, n. ${ }^{\circ}$ 3, jul-set. 2003.

Lüdke, M. Métodos de coleta de dados: observação, entrevista e análise documental. In: Lüdke, M; André, M. L. Pesquisa em Educação: Abordagens qualitativas 6. ed. Reimp. São Paulo: EPU. 1986. cap. 3, p. 25-44.

Marcelino, Gileno F. Gestão Estratégica de Universidade. Brasília: UnB, 2003. Cap.3, p.71.

Marconi, Mariana A. e Lakatos, Eva M. Metodologia científica. 3. a ed. São Paulo: Atlas, 2000. p. 305.

Moreira, F. F.; Sedrani, L. G. M. e Lima, R. C. O que é o Balanced Scorecard?: A evolução 
do BSC, de um sistema de indicadores para um modelo de gestão estratégica, 2005.

Disponível em: http://www.3gen.com.br/files/balanced_scorecard.pdf. Acesso em 10/3/07.

Oliveira, D. P. R. Holding. Administração corporativa e unidade estratégica de negócio. 3. a ed. São Paulo: Atlas, 2003. p. 139.

Oliveira, D. P. R. Planejamento estratégico: conceitos metodologia práticas. 20 . $^{\text {e }}$ ed. São Paulo: Atlas, 2004. p. 335.

Pedro, José Maria. O Balanced Scorecard (BSC) no Setor Público. Revista Informação e Informática, 2004. Disponível na Internet: <http://www.inst-informatica.pt/v20/documentos/ p_rev_28/Artigo2.pdf>. Acesso em 18/10/2006.

Perez, M. M. e Famá, Rubens. Ativos Intangíveis e o Desempenho Empresarial. Revista Contabilidade e Finanças. São Paulo, v. 1, n. 40, jan./abr. 2006. Disponível na Internet: <http://www.eac.fea.usp.br/ cadernos/completos/cad40/marcelo_rubens_pg7a24.pdf>. Acesso em: 30/1/2007>.

Santos Neves, Maurício dos e Palmeira Filho, Pedro Lins. Balanced scorecard como catalisador da gestão estratégica: remédio ou placebo?, In: XXII ENEGEP - Encontro Nacional de Engenharia de Produção, Curitiba, 2002. Disponível na Internet: http://www.gpi.ufrj.br>. Acesso em 17/12/06.

Soares Jr, Heles; Prochnik, Victor. Experiências comparadas de implantação do Balance Scorecard no Brasil. In: XVII Congresso Latino Americano de Estratégia, 28/30 abril de 2004. Santa Catarina. Disponível na Internet: <http://www.ie.ufrj.br/cadeiasprodutivas/pdfs/ implantação_do_balanced_scorecard_no_brasil.pdf>. Acesso em 13/03/07.

Symnetics - Business Transfomation. O que é o balanced scorecard, 2003. Disponível na Internet: <http://www.symnetics.com.br/bscr.asp>. Acesso em 20/04/2007.

Telles, R. Marketing Empresarial. São Paulo: Saraiva, 2003. p. 280

Vergara, Sylvia Constant. Projetos e Relatórios de Pesquisa em Administração. 7. ed. São Paulo: Atlas, 2006.

VII Congresso Internacional del CLAD sobre la Reforma del Estado y de la Administración Pública. Medidas de desempenho organizacional em organizações públicas brasileiras. Lisboa, Portugal, 811 Oct. 2002, 16 p. 
ANEXOS 


\section{UNIVERSIDADE DE BRASÍLIA}

FACULDADE DE ADMINISTRAÇÃO, CONTABILIDADE, ECONOMIA, CIÊNCIA DA INFORMAÇÃO E DOCUMENTAÇÃO-FACE

CURSO DE ESPECIALIZAÇÃO EM DESENVOLVIMENTO GERENCIAL

\section{ENTREVISTA COM OS DIRETORES DO CESPE}

\section{campo A}

1 Unidade Administrativa:

CESPE

2 Nome:

3 Cargo que ocupa na IE:

4 Cargo que ocupa no CESPE:

campo B

5 O CESPE utiliza algum tipo de plano estratégico formal ou não-formal? Em caso afirmativo especifique qual e explique como funciona.

6 Como e quando é possível afirmar que o CESPE vai bem ou não? Que indicadores de gestão são utilizados para acompanhar o desempenho geral do CESPE?

7 Com que freqüência esses indicadores são utilizados?

8 Qual a missão institucional do CESPE:

9 Com base em sua experiência faça uma análise dos anseios e expectativas da administração do CESPE na visão institucional.

10 Com base em sua experiência faça uma avaliação da situação interna do CESPE no que se refere aos seus pontos fortes e fracos. 
11 Com base em sua experiência faça uma análise das ameaças, oportunidades e anseios da administração do CESPE no que se refere ao ambiente externo da empresa.

12 Quais são os objetivos institucionais do CESPE? 


\section{QUESTIONÁRIO COLABORADOR}

O presente questionário enquadra-se no âmbito de uma dissertação do Curso de Especialização em Desenvolvimento Gerencial, subordinada ao tema "Viabilidade de implantação do Balanced Scorecard em uma universidade pública, tomando-se como base uma unidade descentralizada da Universidade de Brasília (UnB)". Pretende-se com este trabalho recolher informação que permita estudar a cultura orgnizacional do CESPE, quais os principais indicadores de desempenho e proceder uma análise sobre as possibilidades de implantação de um novo modelo de gestão. Sua colaboração é extremamente importante para a consecução dos objetivos deste estudo, razão pela qual agradecemos a resposta a ser dada às seguintes questões.

1 Habilitação acadêmica (Assinale o grau mais elevado)

\begin{tabular}{|l|l|l|l|}
\hline $1 . \circ$ GRAU COMPLETO & & GRADUAÇÃO & \\
\hline $1 .{ }^{\circ}$ GRAU INCOMPLETO & & MESTRADO & \\
\hline 2. GRAU COMPLETO & & DOUTORADO & \\
\hline 2.. GRAU INCOMPLETO & & PÓS-DOUTORADO & \\
\hline
\end{tabular}

2 Categoria profissional

\begin{tabular}{|l|l|l|l|}
\hline Administrativo & & Técnico nível superior & \\
\hline Assistente em Administração & & Técnico de Informática & \\
\hline Técnico nível médio & $\begin{array}{l}\text { Técnico Superior de } \\
\text { Informática }\end{array}$ & \\
\hline Outro & \multicolumn{2}{|l}{} \\
\hline
\end{tabular}

3 Você tem conhecimento sobre a existência de um plano estratégico no âmbito da FUB.
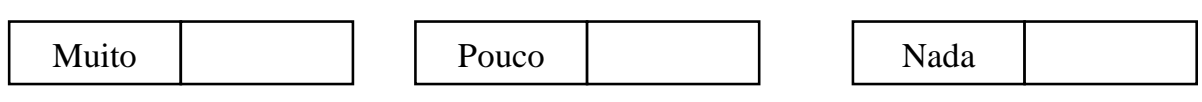

4 Você tem conhecimento sobre a existência de um plano estratégico no âmbito do CESPE.
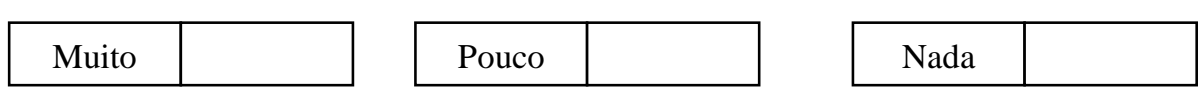
5 No seu entendimento, o estabelecimento de um plano estratégico pode melhorar as relações internas de trabalho?

\begin{tabular}{|l|l|}
\hline Muito & \\
\hline
\end{tabular}

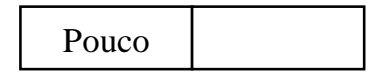

\begin{tabular}{|c|c|}
\hline Nada & \\
\hline
\end{tabular}

6 A missão de uma empresa deve descrever o propósito da organização, identificar o negócio que a organização participa no presente e no futuro, delinear a estratégia a ser seguida, incorporar valores compartilhados e os comportamentos esperados de seus colaboradores. Em síntese, é a razão de ser de uma organização. Considerando uma escala de 1 = nada adequada a 5 = muito adequada, assinale o grau de adequabilidade de cada uma das hipóteses seguintes, como missão da estratégia.

\begin{tabular}{|l|l|l|l|l|l|}
\cline { 2 - 5 } \multicolumn{1}{c|}{} & 1 & 2 & 3 & 4 & 5 \\
\hline $\begin{array}{l}\text { Fazer parte de uma instituição de ensino superior público } \\
\text { com qualidade, competitividade, utilidade e notoriedade }\end{array}$ & & & & & \\
\hline Prestar serviços com qualidade em todo o Brasil & & & & & \\
\hline $\begin{array}{l}\text { Fazer parte de uma equipe de profissionais altamente } \\
\text { qualificados }\end{array}$ & & & & & \\
\hline Transmitir conhecimentos a outrem & & & & & \\
\hline $\begin{array}{l}\text { Criar, difundir e transmitir cultura e tecnologia e promover } \\
\text { o desenvolvimento da região em que se insere }\end{array}$ & & & & & \\
\hline $\begin{array}{l}\text { Fazer parte de uma instituição de ensino superior público } \\
\text { de referência nacional }\end{array}$ & & & & & \\
\hline
\end{tabular}

7 A visão de uma organização é o estado futuro que se pretende chegar. Deverá expressar como a organização quer ser percebida pelo mundo. Considerando uma escala de 1 = nada adequada a 5 = muito adequada assinale o grau de adequabilidade de cada uma das hipóteses seguintes como visão da estratégia.

\begin{tabular}{|l|l|l|l|l|l|}
\cline { 2 - 5 } \multicolumn{1}{c|}{} & 1 & 2 & 3 & 4 & 5 \\
\hline $\begin{array}{l}\text { Ser uma organização de excelência na região em que se } \\
\text { insere }\end{array}$ & & & & & \\
\hline $\begin{array}{l}\text { Ser parte de uma instituição de ensino superior pública } \\
\text { com qualidade, competitividade e notoriedade }\end{array}$ & & & & & \\
\hline $\begin{array}{l}\text { Criar, difundir e transmitir cultura, tecnologia e promover } \\
\text { o desenvolvimento da região em que se insere }\end{array}$ & & & & & \\
\hline $\begin{array}{l}\text { Ser um centro de referência nacional que faz parte de } \\
\text { uma instituição pública }\end{array}$ & & & & & \\
\hline Ser um pólo nacional de referência & & & & & \\
\hline
\end{tabular}

8 Considera importante a existência de mecanismos que permitam acompanhar e avaliar a evolução da estratégia?

\begin{tabular}{|c|c|}
\hline Muito & \\
importante & \\
\hline
\end{tabular}

\begin{tabular}{|c|c|}
\hline $\begin{array}{c}\text { Pouco } \\
\text { importante }\end{array}$ & \\
\hline
\end{tabular}

\begin{tabular}{|c|c|}
\hline Nada & \\
importante & \\
\hline
\end{tabular}


9 O acompanhamento e avaliação da estratégia podem ser feitos através da utilização de indicadores. Considerando a hipótese da implementação de um sistema desse tipo no CESPE, assinale o grau de importância (escala de 1 = nada importante a 5 = muito importante) em relação a cada um dos seguintes indicadores. Caso julgue necessário, poderá inserir novos indicadores conforme seja necessário. Entre os parênteses se encontra a explicação de alguns indicadores.

\begin{tabular}{|c|c|c|c|c|c|}
\hline & 1 & 2 & 3 & 4 & 5 \\
\hline \multicolumn{6}{|l|}{ Indicadores financeiros } \\
\hline \multicolumn{6}{|l|}{$\%$ aumento das receitas } \\
\hline \multicolumn{6}{|l|}{$\begin{array}{l}\text { Tempo médio de avaria de equipamentos (mede a vida } \\
\text { útil dos equipamentos) }\end{array}$} \\
\hline \multicolumn{6}{|l|}{$\begin{array}{l}\text { Custos com pessoal/custos totais (o quanto se gasta } \\
\text { com pessoal) }\end{array}$} \\
\hline \multicolumn{6}{|l|}{$\begin{array}{l}\text { Custos com pesquisa/custos totais (o quanto se gasta } \\
\text { com pesquisas) }\end{array}$} \\
\hline \multicolumn{6}{|l|}{$\begin{array}{l}\text { Custos de treinamento/custos totais (quanto se gasta } \\
\text { com treinamento de pessoal para que estes } \\
\text { desempenhem suas atividades com qualidade e } \\
\text { eficiência) }\end{array}$} \\
\hline \multicolumn{6}{|l|}{$\begin{array}{l}\text { Custos com a atividade fim/custos totais (quanto se } \\
\text { gasta com as atividades cotidianas de trabalho) }\end{array}$} \\
\hline \multicolumn{6}{|l|}{$\begin{array}{l}\text { Custos por evento/custos totais (quanto se gasta por } \\
\text { eventos) }\end{array}$} \\
\hline \multicolumn{6}{|l|}{$\begin{array}{l}\text { Custos por aluno (quando se gasta com os alunos que } \\
\text { prestam serviço ao CESPE) }\end{array}$} \\
\hline \multicolumn{6}{|l|}{$\begin{array}{l}\text { Custos por professores (quanto se gasta com os } \\
\text { professores que elaboram algum tipo de trabalho ao } \\
\text { CESPE) }\end{array}$} \\
\hline \multicolumn{6}{|l|}{$\begin{array}{l}\text { Custos por funcionário do quadro e extra-quadro (quanto } \\
\text { se gasta com o pessoal do quadro e extra-quadro) }\end{array}$} \\
\hline \multicolumn{6}{|l|}{$\begin{array}{l}\text { Receita oriunda de novos clientes (quanto cada cliente } \\
\text { contribui para o total das receitas) }\end{array}$} \\
\hline \multicolumn{6}{|l|}{$\begin{array}{l}\text { Receita oriunda de novos produtos e serviços (quanto a } \\
\text { oferta de novos serviços à comunidade contribui à } \\
\text { receita total) }\end{array}$} \\
\hline \multicolumn{6}{|l|}{$\begin{array}{l}\text { Rentabilidade dos clientes medida pelo sistema ABC } \\
\text { (quanto os clientes contribuem à receita) }\end{array}$} \\
\hline $\begin{array}{l}\text { Porcentagem de clientes não-lucrativos (rentabilidade } \\
\text { dos clientes que demandam os serviços do CESPE e } \\
\text { não dão lucro) }\end{array}$ & & & & & \\
\hline
\end{tabular}




\begin{tabular}{|c|c|c|c|c|c|}
\hline & 1 & 2 & 3 & 4 & 5 \\
\hline \multicolumn{6}{|l|}{ Indicadores de clientes } \\
\hline \multicolumn{6}{|l|}{$\begin{array}{l}\text { Lucro por segmento de cliente (quanto cada segmento } \\
\text { de clientes contribui à receita) }\end{array}$} \\
\hline \multicolumn{6}{|l|}{$\begin{array}{l}\text { Participação de mercado nos segmentos alvo (quanto } \\
\text { dos clientes alvo se conseguiu atingir) }\end{array}$} \\
\hline \multicolumn{6}{|l|}{$\begin{array}{l}\text { Porcentagem de clientes não-lucrativos (clientes que } \\
\text { demandam os serviços do CESPE e não dão lucro) }\end{array}$} \\
\hline \multicolumn{6}{|l|}{$\begin{array}{l}\text { Número de clientes estratégicos (quantos e quais são os } \\
\text { clientes que trazem lucro para o CESPE) }\end{array}$} \\
\hline \multicolumn{6}{|l|}{$\begin{array}{l}\text { Pesquisa entre os clientes estratégicos sobre } \\
\text { conhecimento e preferência da marca UnB/CESPE } \\
\text { (como os clientes mais importantes percebem e } \\
\text { valorizam a marca UnB/CESPE) }\end{array}$} \\
\hline \multicolumn{6}{|l|}{$\begin{array}{l}\text { Custo por cliente conquistado (quanto cada novo cliente } \\
\text { custa para o CESPE) }\end{array}$} \\
\hline \multicolumn{6}{|l|}{$\begin{array}{l}\text { Número de recomendações a novos clientes (quantas } \\
\text { recomendações são feitas por cliente) }\end{array}$} \\
\hline \multicolumn{6}{|l|}{$\begin{array}{l}\text { Número de novos clientes conquistados com base em } \\
\text { recomendações dos clientes existentes (quantos novos } \\
\text { clientes são conquistados por informações dos clientes } \\
\text { antigos) }\end{array}$} \\
\hline \multicolumn{6}{|l|}{$\begin{array}{l}\text { Número de testemunhos de clientes fiéis (quantidade de } \\
\text { propaganda de boca dos antigos clientes) }\end{array}$} \\
\hline \multicolumn{6}{|l|}{$\begin{array}{l}\text { Número de sugestões de clientes fiéis para melhorias } \\
\text { nos produtos e serviços (recomendações dos clientes } \\
\text { antigos para melhoria dos serviços) }\end{array}$} \\
\hline \multicolumn{6}{|l|}{$\begin{array}{l}\text { Retenção de clientes (quanto dos clientes fiéis } \\
\text { permanece como tal) }\end{array}$} \\
\hline $\begin{array}{l}\text { Número de acordos para o desenvolvimento conjunto de } \\
\text { serviços (quantidade de parcerias para desenvolvimento } \\
\text { dos serviços) }\end{array}$ & & & & & \\
\hline
\end{tabular}

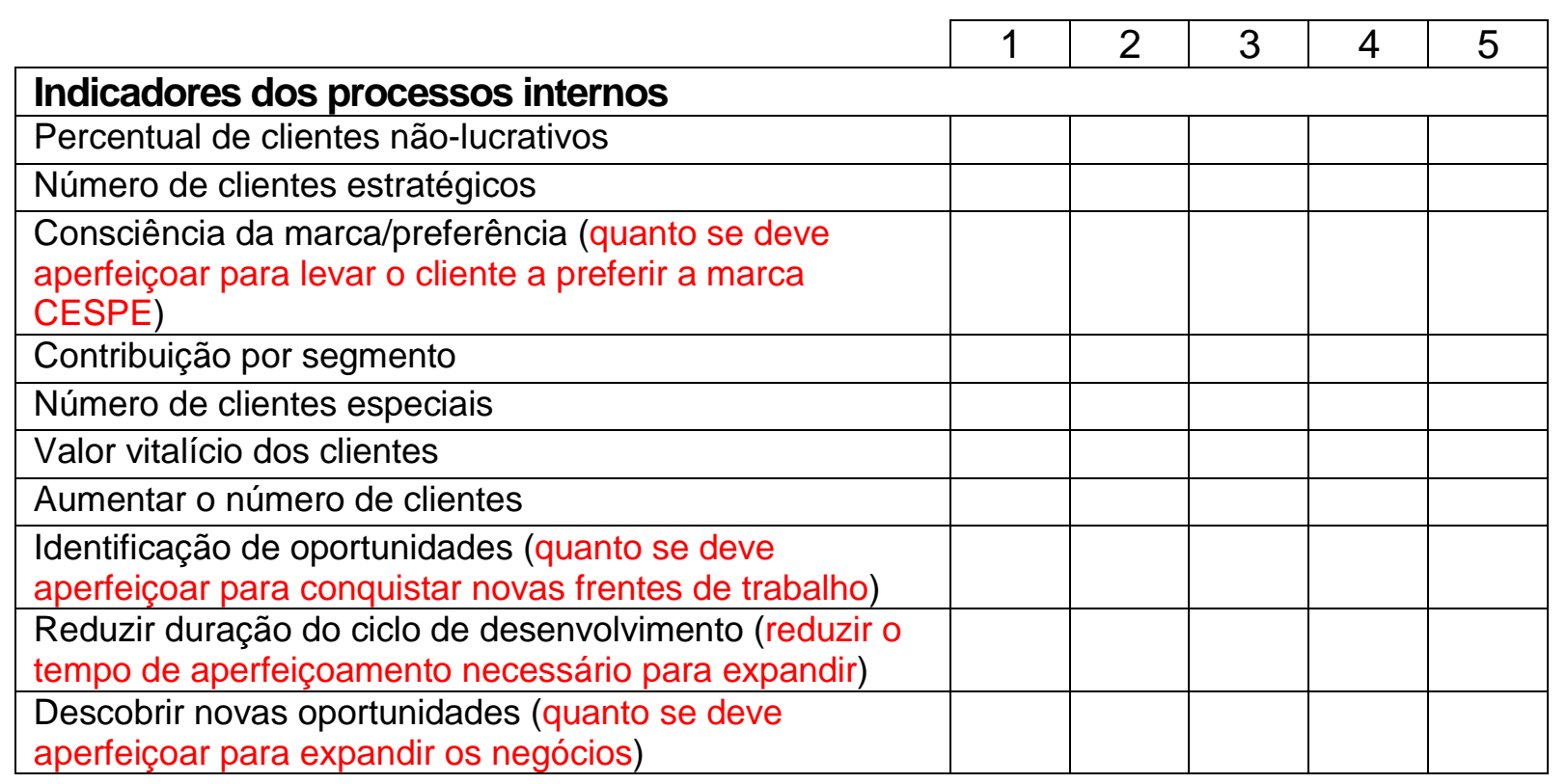




\begin{tabular}{|l|l|l|l|l|l|}
\cline { 2 - 5 } \multicolumn{1}{l|}{} & 1 & 2 & 3 & 4 & 5 \\
\hline $\begin{array}{l}\text { Indicadores de aprendizagem e crescimento } \\
\begin{array}{l}\text { Prontidão do capital humano (quantos empregados bem } \\
\text { treinados empresa pode contar) }\end{array}\end{array}$ & & & & \\
\hline $\begin{array}{l}\text { Rotatividade do pessoal chave (pessoal encarregado de } \\
\text { funções desempenhando outras funções e agregando } \\
\text { conhecimento) }\end{array}$ & & & & & \\
\hline $\begin{array}{l}\text { Resultados de pesquisa sobre cultura dos empregados } \\
\text { (mensura o nível de satisfação dos funcionários, que } \\
\text { propicia a retenção deste na empresa e sua maior } \\
\text { produtividade) }\end{array}$ & & & & & \\
\hline $\begin{array}{l}\text { Porcentagem dos objetivos dos empregados vinculados } \\
\text { aos processos de clientes e respectivos indicadores de } \\
\text { resultados do BSC (objetivos dos empregados } \\
\text { vinculados à satisfação dos clientes) }\end{array}$ & & & & & \\
\hline $\begin{array}{l}\text { Acesso do empregado ao sistema de gestão do } \\
\text { conhecimento do cliente }\end{array}$ & & & & & \\
\hline $\begin{array}{l}\text { Objetivos dos empregados, conectados ao BSC } \\
\text { (empregados responsabilizando-se pelo sucesso da } \\
\text { estratégia) }\end{array}$ & & & & & \\
\hline Habilidades multidisciplinares & & & & & \\
\hline Cultura de criatividade e inovação & & & & & \\
\hline
\end{tabular}

